\title{
Petroleum Systems of the United States
}

U.S. GEOLOGICAL SURVEY BULLETIN 1870 


\section{AVAILABILITY OF BOOKS AND MAPS OF THE U.S. GEOLOGICAL SURVEY}

Instructions on ordering publications of the U.S. Geological Survey, along with prices of the last offerings, are given in the current-year issues of the monthly catalog "New Publications of the U.S. Geological Survey." Prices of available U.S. Geological Survey publications released prior to the current year are listed in the most recent annual "Price and Availability List." Publications that are listed in various U.S. Geological Survey catalogs (see back inside cover) but not listed in the most recent annual "Price and Availability List" are no longer available.

Prices of reports released to the open files are given in the listing "U.S. Geological Survey Open-File Reports," updated monthly, which is for sale in microfiche from the U.S. Geological Survey, Books and Open-File Reports Section, Federal Center, Box 25425, Denver, CO 80225 . Reports released through the NTIS may be obtained by writing to the National Technical Information Service, U.S. Department of Commerce, Springfield, VA 22161; please include NTIS report number with inquiry.

Order U.S. Geological Survey publications by mail or over the counter from the offices given below.

\section{BY MAIL}

\section{Books}

Professional Papers, Bulletins, Water-Supply Papers, Techniques of Water-Resources Investigations, Circulars, publications of general interest (such as leaflets, pamphlets, booklets), single copies of Earthquakes \& Volcanoes, Preliminary Determination of Epicenters, and some miscellaneous reports, including some of the foregoing series that have gone out of print at the Superintendent of Documents, are obtainable by mail from

\section{U.S. Geological Survey, Books and Open-File Reports Federal Center, Box 25425 Denver, CO 80225}

Subscriptions to periodicals (Earthquakes \& Volcanoes and Preliminary Determination of Epicenters) can be obtained ONLY from the

\section{Superintendent of Documents \\ Government Printing Office \\ Washington, D.C. 20402}

(Check or money order must be payable to Superintendent of Documents.)

\section{Maps}

For maps, address mail orders to

\section{U.S. Geological Survey, Map Distribution \\ Federal Center, Box 25286 \\ Denver, CO 80225}

Residents of Alaska may order maps from
Alaska Distribution Section, U.S. Geological Survey, New Federal Building - Box 12 101 Twelfth Ave., Fairbanks, AK 99701

\section{OVER THE COUNTER}

\section{Books}

Books of the U.S. Geological Survey are available over the counter at the following Geological Survey Public Inquiries Offices, all of which are authorized agents of the Superintendent of Documents:

- WASHINGTON, D.C.--Main Interior Bldg., 2600 corridor, 18 th and C Sts., NW.

- DENVER, Colorado--Federal Bldg., Rm. 169, 1961 Stout St.

- LOS ANGELES, California--Federal Bldg., Rm. 7638, 300 N. Los Angeles St.

- MENLO PARK, California--Bldg. 3 (Stop 533), Rm. 3128, 345 Middlefield Rd.

- RESTON, Virginia--503 National Center, Rm. 1C402, 12201 Sunrise Valley Dr.

- SALT LAKE CITY, Utah--Federal Bldg., Rm. 8105, 125 South State St.

- SAN FRANCISCO, California--Customhouse, Rm. 504, 555 Battery St.

- SPOKANE, Washington--U.S. Courthouse, Rm. 678, West 920 Riverside Ave..

- ANCHORAGE, Alaska--Rm. 101, 4230 University Dr.

- ANCHORAGE, Alaska--Federal Bldg, Rm. E-146, 701 C St.

\section{Maps}

Maps may be purchased over the counter at the U.S. Geological Survey offices where books are sold (all addresses in above list) and at the following Geological Survey offices:

- ROLLA, Missouri--1400 Independence Rd.

- DENVER, Colorado--Map Distribution, Bldg. 810, Federal Center

- FAIRBANKS, Alaska--New Federal Bldg., 101 Twelfth Ave. 


\section{Petroleum Systems of the United States}

LESLIE B. MAGOON, Editor 


\title{
DEPARTMENT OF THE INTERIOR \\ DONALD PAUL HODEL, Secretary
}

\author{
U.S. GEOLOGICAL SURVEY \\ Dallas L. Peck, Director
}

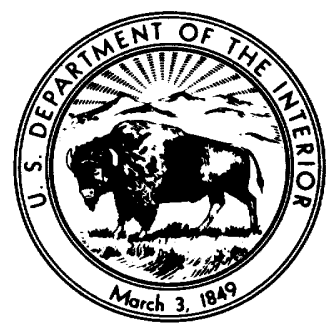

Any use of trade names and trademarks

in this publication is for descriptive

purposes only and does not constitute

endorsement by the U.S. Geological Survey

For sale by the

Books and Open-File Reports Section

U.S. Geological Survey

Federal Center, Box 25425

Denver, CO 80225

Library of Congress Cataloging-in-Publication Data

Petroleum systems of the United States.

(U.S. Geological Survey bulletin ; 1870)

Includes bibliographies.

Supt. of Docs. no.: । 19.3:1870

1. Petroleum-Geology-United States. 2. Petroleum-

United States-Reserves. I. Magoon, Leslie B. II. Series.

QE75.B9 no. $1870 \quad 557.3 \mathrm{~s} \quad 88-600313$

[TN872.A5]

[553 .2'82] 


\section{CONTENTS}

Abstract

Leslie B. Magoon 1

The petroleum system-A classification scheme for research, exploration, and resource assessment 2 Leslie B. Magoon

Role of amount and type of organic matter in recognition of petroleum source rocks $\mathbf{1 6}$ Jerry L. Clayton

Characteristics of carbonate source rocks of petroleum $\mathbf{2 0}$ James G. Palacas

Geothermics of petroleum systems: Implications of the stabilization of kerogen thermal maturation after a geologically brief heating duration at peak temperature $\mathbf{2 6}$

Charles E. Barker

Thermal maturity $\mathbf{3 0}$

J. David King and Mark J. Pawlewicz

Primary and secondary hydrocarbon migration $\mathbf{3 3}$ Charles W. Spencer

Structure 36

William J. Perry, Jr.

Types of seals as related to migration and entrapment of hydrocarbons 39

Gregory F. Ulmishek

Sandstone reservoirs $\mathbf{4 1}$

Christopher J. Schenk

Natural gas 44

Keith A. Kvenvolden

Natural gas hydrate 46

Timothy S. Collett and Keith A. Kvenvolden

Tight gas reservoirs 48

Ben E. Law and Charles W. Spencer

Natural gas in fractured shale-The Appalachian Devonian black shale gas system $\mathbf{5 0}$ John B. Roen

Coal-bed methane $\mathbf{5 2}$

Ben E. Law 
Classification and composition of crude oil 54

Jerry L. Clayton

Heavy oil and natural bitumen $\mathbf{5 7}$

Richard F. Meyer

Geochemical correlations in petroleum systems 60

Donald E. Anders

Computer applications 65

Kenneth I. Takahashi, Thaddeus S. Dyman, and Leslie B. Magoon

\section{FIGURES}

1. Cross section showing essential elements of petroleum system 4

2. Map showing extent of petroleum system 6

3. Geologic cross section showing elements of the Beluga-Sterling(.) petroleum system 7

4. Geologic cross section showing elements of the Torok-Nanushuk(.) petroleum system 8

5. Geologic cross section showing elements of the Ellesmerian(!) petroleum system 8

6. Geologic cross section showing elements of the Tuxedni-Hemlock(.) petroleum system 9

7. Van Krevelen diagram showing three evolution paths for kerogen 18

8. Biomarker distributions that show the origin of gilsonite and tar sand oil 63

\section{TABLES}

1. Summary of models that incorporate geologic process to explain the distribution of petroleum in nature 3

2. Definitions for level of certainty 6

3. Classification scheme for the petroleum system 7

4. One petroleum system in each class and the number of similar systems identified in the United States 7

5. Formal meetings that were required to implement the petroleum system classification scheme $\mathbf{1 1}$

6. Petroleum systems within the United States $\mathbf{1 2}$

7. Recent publications in English referring to carbonate and carbonate-evaporite rocks as potential source beds of petroleum 20

8. Characteristics of low- to medium-maturity oils derived from carbonate versus shale source rocks

9. Typical composition of a $35^{\circ}$ API gravity crude oil $\mathbf{5 4}$

10. Classification of oils according to scheme of Tissot and Welte (1984) 55

11 . The most commonly used correlation parameters and their general application in gas-oil-source studies 61

12. Some commonly used correlation parameters to show the origin of gilsonite and tar sand oil 64

13. Computer systems specifications and software, Branch of Petroleum Geology 67

14. File structure for an 80-column card-image format for the petroleum system data base $\mathbf{6 8}$ 


\section{PETROLEUM SYSTEMS OF THE UNITED STATES}

\section{Abstract

\author{
Leslie B. Magoon, Editor
}

This publication in 18 individually authored summaries by U.S. Geological Survey scientists (1) explains and classifies the petroleum system, (2) presents a preliminary listing of petroleum systems within the United States, and (3) describes current research on the essential elements of these systems.

The petroleum system is proposed as a unique approach to research, exploration, and resource assessment. A petroleum system includes all those elements that are essential for an oil and gas deposit to exist in nature. The basic elements include a petroleum source rock, migration path, reservoir rock, seal, and trap. All elements must be placed correctly in time and space for a petroleum system to occur. A petroleum deposit includes high concentrations of any of the following substances: thermal and microbial natural gas, condensate, oil, and solid bitumen. The description of a petroleum system includes its stratigraphic limits, geographic extent, and geologic timespan. The system is named using the stratigraphic nomenclature for the source rock and the most important reservoir rock; these two names are then separated by a hyphen. The confidence that a particular source rock generated hydrocarbons that are trapped in a certain reservoir is expressed in the level of certainty: known (!), hypothetical (.), or speculative (?). The symbol for the level of certainty is placed at the end of the petroleum system name, for example, Phosphoria-Weber(!), a known system. Petroleum systems can be classified by using criteria such as source and reservoir rock type and complexity of its geologic history.

A list of most of the petroleum systems within the United States was developed by USGS geologists who are specialists in the petroleum geology for different parts of the United States. In a series of meetings, these specialists identified and named the petroleum systems in their respective areas and provided other information on source and reservoir type, so that the systems could be classified. The results from this exercise are included in the petroleum system chapter as a table.

Most chapters in this bulletin are devoted to current research on the essential elements of the petroleum system. Topics included are siliciclastic and carbonate source rocks, geothermal gradient, thermal maturity, hydrocarbon migration, seals, structure, reservoirs, computer file structure, and the different types of petroleum deposits. Each author defines the essential element, discusses the current research for that element, and provides supporting references. 


\title{
The Petroleum System-A Classification Scheme for Research, Exploration, and Resource Assessment
}

\author{
By Leslie B. Magoon
}

\section{INTRODUCTION}

Geologists are continually looking for new ways to organize information or data into arrays to be interpreted in innovative ways to answer a specific question. One of the oldest ways, but still a very useful one, is to organize information into a geologic map. Over the last four decades, many new maps have been invented by petroleum geologists that relate to the reservoir rocks, structure, stratigraphy, and source rocks. With the advent of the computer, a plethora of ways to organize geologic information is available; in fact, finding the proper way to organize is sometimes a problem. As more geological, geophysical, and geochemical information about petroleum occurrence accrues, there is a need to organize and categorize our ideas into conceptual models based on geologic processes. These models must then be classified so that comparative studies can be carried out.

Various papers have added significantly to our understanding of petroleum occurrence, some of which are identified in table 1. The papers included on this table were chosen because the subject is closest to the petroleum system. Papers relating to basin studies (Zieglar and Spotts, 1978; Welte and Yukler, 1984; Klemme, 1986) and play or prospect analysis (Sluijk and Nederlof, 1984; Bird, 1986) were purposely left out because of emphasis. The petroleum system emphasizes the genetic relation between a particular source rock and the resulting petroleum accumulation; basin studies emphasize structural depressions and the included sedimentary rocks regardless of the relation to any petroleum deposits; and the play or prospect approach emphasizes whether the present-day trap is detectable with available technology or tools.

Seven items are identified on table 1 that can be divided into two broad categories: geologic parameters and evaluation criteria. On this table, all papers discussed at least one geologic parameter in considerable detail or at least acknowledged their importance. For example, all papers acknowledged the importance of migration but did not discuss this process in detail. The evaluation criteria were discussed in only three papers. The naming nomenclature using stratigraphic units was used in Dow (1974) and discussed in detail by Magoon (1987); the level of certainty in one paper (Magoon, 1987); and the classification schemes in two papers (Bois and others, 1982; Magoon, 1987). This table is by no means exhaustive, but is shown to put the petroleum system into historical perspective.

Remember that the petroleum system implies a genetic relation between the source rock and a series of accumulations, but it is not proof of the relation. The level of confidence in this genetic relation is indicated with the level of certainty, and can be improved using various geological, geophysical, and geochemical techniques. In addition, when defining a system, scale is as important to the petroleum system as it is to the geologic map. A small-scale geologic map includes more regional or general information on a large area when compared to a large-scale map that includes more detailed information on a small area. Similarily, any one petroleum system identified on a regional scale, such as in this study, may on closer examination be subdivided into smaller systems. The purpose of this paper is to define a petroleum system, to name the system, to determine its level of certainty, and then to classify the system.

\section{PETROLEUM SYSTEM}

A petroleum system includes all those geologic elements and processes that are essential for an oil and gas deposit to exist in nature. These basic elements include a petroleum source rock, migration path, reservoir rock, seal, and trap; and the geologic processes that create each of these basic elements. All these elements must be correctly placed in time and space so that organic matter included in a source rock can be converted into a petroleum deposit. A petroleum system exists wherever all the basic elements are known to occur or are suspected to occur.

\section{CHARACTERISTICS AND LIMITS}

The stratigraphic, areal, and temporal extent of the petroleum system is specific. Stratigraphically, the system is limited to the following rock units: a petroleum source rock, rocks through which migration has occurred, reservoir rock (trap), and rock overburden required for maturity (fig. 1). The areal extent of the petroleum system is defined by a line that circumscribes the mature 
Table 1. Summary of models that incorporate geologic process to explain the distribution of petroleum in nature

[Origin, includes richness, type, and thermal maturity of petroleum source rock; migration, includes the movement of oil, gas, or any other hydrocarbon through the country rock; accumulation, includes the presence of a reservoir rock, seal, trap, and a high concentration of hydrocarbons; timing, traps formed before the hydrocarbons migrated; ++ , discussed in detail; + , discussed in general terms; - , did not discuss]

\begin{tabular}{|c|c|c|c|c|c|c|c|c|}
\hline \multirow[b]{2}{*}{ Reference } & \multirow[b]{2}{*}{ Descriptive phrase } & \multicolumn{4}{|c|}{ Geologic parameters } & \multicolumn{3}{|c|}{ Evaluation criteria } \\
\hline & & Origin & $\begin{array}{c}\text { Migra- } \\
\text { tion }\end{array}$ & $\begin{array}{c}\text { Accumu- } \\
\text { lation }\end{array}$ & $\begin{array}{c}\text { Tim- } \\
\text { ing }\end{array}$ & $\begin{array}{l}\text { Nomen- } \\
\text { clature }\end{array}$ & $\begin{array}{l}\text { Level of } \\
\text { certainty }\end{array}$ & $\begin{array}{c}\text { Classification } \\
\text { scheme }\end{array}$ \\
\hline Dow (1974) & Oil system & ++ & + & ++ & + & + & - & - \\
\hline Bois (1975) & Petroleum-zone & + & + & ++ & - & - & - & - \\
\hline White (1980) & Facies-cycle wedges & + & + & ++ & + & - & - & - \\
\hline Bois and others (1982) & Petroleum-zone & ++ & + & ++ & + & - & - & + \\
\hline Demaison (1984) & Generative basin & ++ & + & + & + & - & - & - \\
\hline Meissner and others (1984) & Hydrocarbon machines & ++ & + & + & + & - & - & - \\
\hline Ulmishek (1986) & Independent petroliferous system & ++ & + & ++ & + & - & - & - \\
\hline Magoon (1987) & Petroleum system & + & + & + & + & ++ & ++ & ++ \\
\hline
\end{tabular}

source rock and all oil and gas deposits, conventional and unconventional, originating from that source (fig. 2).

On the cross section (fig. 1), there are two sedimentary basins, three plays, and one petroleum system. The literature includes numerous ways to classify or identify a sedimentary basin, but in simple terms it is a depression into which sediments are deposited and is usually expressed as a lenticular body or prism of sedimentary rock. As expressed from the interface between the sedimentary rock and basement complex, there are two lenticular bodies of sedimentary rock or two basins on the cross section. Knowledge of the detailed stratigraphy within these two basins might reveal even more sedimentary basins. Hence, by studying a sedimentary basin, a geologist may or may not study the elements essential to petroleum accumulations. The three plays shown on the cross section are (1) a series of suspected traps along an anticlinal trend, (2) a series of suspected traps along a stratigraphic pinch-out trend, and (3) any suspected trap within a stratigraphic interval. A prospect is a drillable trap within a play. This play definition is much narrower than that of Dolton and others (1987) and is felt to be more relevant to industry's approach to exploration. Hence, the definition of a play need not include all the essential elements of a petroleum system.

A petroleum system represents sufficient geologic time to assemble all of the basic elements, from the source rock to the last unit, required to form petroleum deposits. A petroleum deposit includes high concentrations of any of the following substances: thermal and microbial natural gas found in conventional reservoirs as well as in gas hydrates, tight sands, fractured shales, and coal beds; condensates, crude oils, heavy oils and solid bitumen reservoired in siliciclastic and carbonate rocks.

A petroleum system can be identified in terms of geochemical correlation of petroleum and source rocks at three levels of certainty: known, hypothetical, and speculative (table 2). In a known petroleum system, in the case of oil, a good geochemical match must exist between the source rock and oil accumulations; or, in the case of natural gas, the gas is produced from a gas source rock. In a hypothetical petroleum system, geochemical information is sufficient to identify a source rock, but no geochemical match exists between source and petroleum deposits. In a speculative petroleum system, the existence of source rocks and petroleum accumulations is postulated entirely on the basis of geologic or geophysical evidence. At the end of the system's name, the level of certainty is indicated by (!) for known, (.) for hypothetical, and (?) for speculative. I propose that the petroleum system designation include the name of the source rock followed by the name of the major reservoir rock and a symbol expressing the level of certainty. For example, the Torok-Nanushuk(.) is a hypothetical system on the North Slope of Alaska comprising the Cretaceous Torok Formation source rock and Nanushuk Group sandstone as the major reservoir (Magoon and Claypool, 1985).

After a petroleum system is identified and named and its level of certainty established, it must be classified (table 3). An identified petroleum system is classified into one of 12 categories, based on the type of source rock (I, II, or III), composition of reservoir rock (siliciclastic or carbonate), and whether the system is purebred or hybrid. A purebred petroleum system was deposited in a geologic setting in which the structural framework did not change significantly during the geologic life of the system; in contrast, a hybrid system includes a major structural reorientation, without which a petroleum system would not have formed. The composition of the reservoir refers to the lithology, either siliciclastic or carbonate, of the largest petroleum deposit. The organic matter type, either I, II, or III, is distinguished on the basis of the hydrogen and oxygen 
indices of the kerogen when plotted on the van Krevelen diagram (Tissot and Welte, 1984). The organic matter type that produced the petroleum reservoired in the largest petroleum deposit is used to classify the system. The largest petroleum deposit refers to a single pool that contains the most inplace hydrocarbons or a series of pools that cumulatively contain the most inplace hydrocarbons in the system at the time of discovery.

By classifying petroleum systems, groupings of similar systems may be revealed, and these groups may serve as analogs for research, exploration, or resource assessment (table 4). For example, the most common type of system has a purebred geologic setting, siliciclastic reservoirs, and type II kerogen, and the Monterey(!) petroleum system is one example of 26 other systems. There were no petroleum systems identified in a hybrid geologic setting, carbonate reservoirs, and type I or type III kerogens. To date, the total number of petroleum systems identified and classified in the 48 conterminous states and Alaska is 119. If important information about each system is collected and categorized, many comparisons and contrasts become apparent and can then be subject for further investigation. To explain further the petroleum system, four examples from Alaska follow. Two of the examples are classified as purebred, and two are hybrid.

\section{EXAMPLES OF PETROLEUM SYSTEMS}

\section{Beluga-Sterling(.)}

In Cook Inlet, Alaska, a significant amount of dry gas is reservoired and produced from Tertiary rocks deposited in a forearc basin (Magoon and Egbert, 1986; fig. 3). At least two stratigraphic units are involved, the Beluga and Sterling Formations, and this geologic setting is classified as a purebred system. Most of the gas is in the Sterling Formation and is reservoired in a mediumgrained, well to fairly well sorted, and slightly conglomeratic sandstone (Crick, 1971; Boss and others, 1976; Hayes and others, 1976). The source for the gas is unclear, but the Beluga and Sterling Formations have considerable coal and type III kerogen (Claypool and others, 1980). The coal and type III kerogen is below or associated with the Sterling Formation, so this source is in a good position to charge overlying reservoirs with microbial gas (Claypool and others, 1980). Because the source of the microbial gas cannot be directly tied to the Beluga Formation, the level of certainty for the BelugaSterling(.) petroleum system is hypothetical, and the system is classified as purebred with siliciclastic reservoirs and type III kerogen source rocks.

\section{Torok-Nanushuk(.)}

On the North Slope of Alaska significant quantities of petroleum are associated with the Nanushuk Group (fig. 4). Oil and gas accumulations are located in anticlines and in combination traps (Collins and Robinson, 1967; Bird, 1985). The geologic setting, a foreland basin, has remained the same during deposition of all the essential elements, and thus the petroleum system is classified as a purebred system. The reservoir rock is feldspar- and lithic-rich sandstone derived from the Brooks Range orogen (Ahlbrandt, 1979; Molenaar, 1983; Molenaar and others, 1987; Huffman, 1985). The source rocks for the hydrocarbons are most likely in the lower part of the Torok Formation, containing a type III

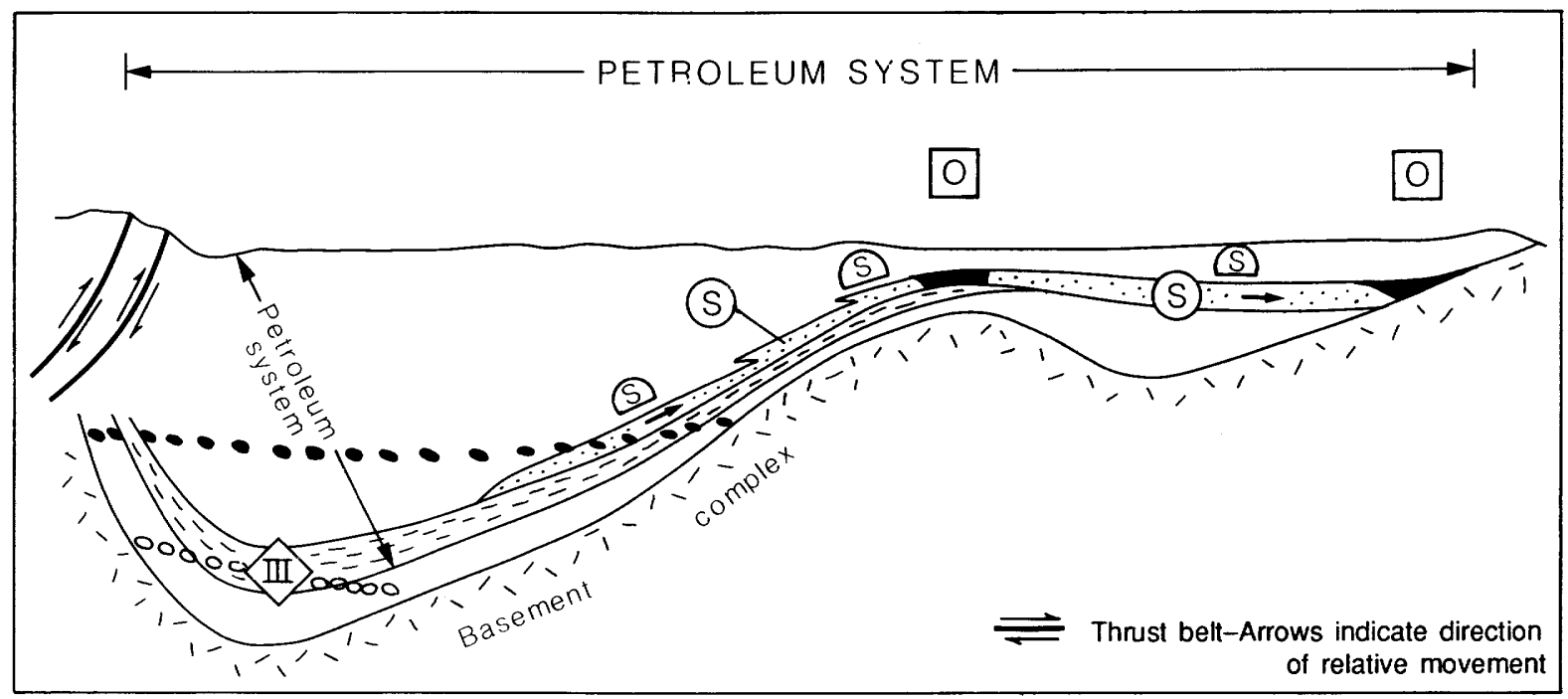

Figure 1. Hypothetical geologic cross section (see fig. 2 for location) of a basin showing the essential elements of a petroleum system. The expanded explanation is appropriate for figures 1-6. 
kerogen, and possibly the underlying pebble shale unit, containing a type III/II kerogen (Magoon and Claypool, 1985). There is considerable geochemical data available on both the oils and source rocks, but a convincing geochemical correlation has not been demonstrated
(Magoon and Bird, 1985; Claypool and Magoon, 1985). The level of certainty for the Torok-Nanushuk(.) petroleum system is hypothetical, and the system is classified as a purebred with siliciclastic reservoirs and type III kerogen source rocks (table 4).

\section{PETROLEUM SYSTEM EXPLANATION}

\section{Source rock}

I) Type I kerogen

III Type II kerogen

(III) Type III kerogen

Reservoir rock

(S) Siliciclastic

(C) Carbonate

Seal rock

(S) Shale

(A) Anhydrite

(G) Gypsum

\section{Lithology}

Shale

Siliciclastic

I. Carbonate mudstone

朢 Carbonate

Stages of organic metamorphism

Diagenesis
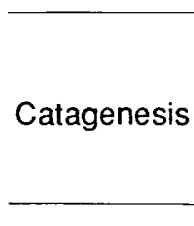

Metagenesis

\section{Petroleum accumulation}

- All types

N Natural bitumens, asphaltites, and asphaltic pyrobitumens

E Oil, extra heavy gravity $\left(<10^{\circ} \mathrm{API}\right)$

H Oil, heavy gravity $\left(10^{\circ} \approx 20^{\circ} \mathrm{API}\right)$

OD Oil, medium gravity $\left(20^{\circ}<45^{\circ} \mathrm{API}\right)$

C Condensate $\left(545^{\circ} \mathrm{API}\right)$

G Thermal gas

M Microbial methane gas

B Gas originating from coal beds

$T$ Gas reservoired in low-porosity and permeable rock

Y Natural gas hydrate

Migration

$\rightarrow$ Indicates direction petroleum migrated

\section{Petroleum products}

Microbial gas

Onset of catagenesis

Oil/condensate

0000000000000

Onset of metagenesis

Thermal gas

Figure 1. Continued.

A Classification Scheme for Research, Exploration, and Resource Assessment 5 


\section{Ellesmerian(!)}

On the North Slope of Alaska, the largest oil field in North America, Prudhoe Bay, is one of several fields reservoired in the Ellesmerian sequence (fig. 5). The oil accumulations are reservoired mostly in siliciclastic rocks that range in age from Late Devonian through Tertiary and also in Carboniferous age carbonates (Bird, 1981; Bird and Magoon, 1987; Alaska Oil and Gas Conservation Commission, 1985).

Two different depositional settings separated by continental rifting were required to complete this petroleum system, thus making it a hybrid system. The first setting, the Arctic platform, includes rocks, deposited on a broad shelf, that range in age from Late Devonian through Early Cretaceous, contains siliciclastic and carbonate rocks, and is designated the Ellesmerian sequence (Lerand, 1973; Bird, 1981). The Ellesmerian system includes three source rocks with mostly type II
Table 2. Definitions for level of certainty

\begin{tabular}{ccc}
\hline Level of certainty & Criteria & Symbol \\
\hline Known & $\begin{array}{c}\text { Oil/source-rock correlation, } \\
\text { or gas reservoired in documented } \\
\text { gas source-rock }\end{array}$ & $(!)$ \\
Hypothetical & $\begin{array}{c}\text { No oil/source-rock correlation, } \\
\text { or gas reservoired near postulated } \\
\text { source rock }\end{array}$ & $()$. \\
Speculative & Geological and geophysical evidence & $(?)$ \\
\hline
\end{tabular}
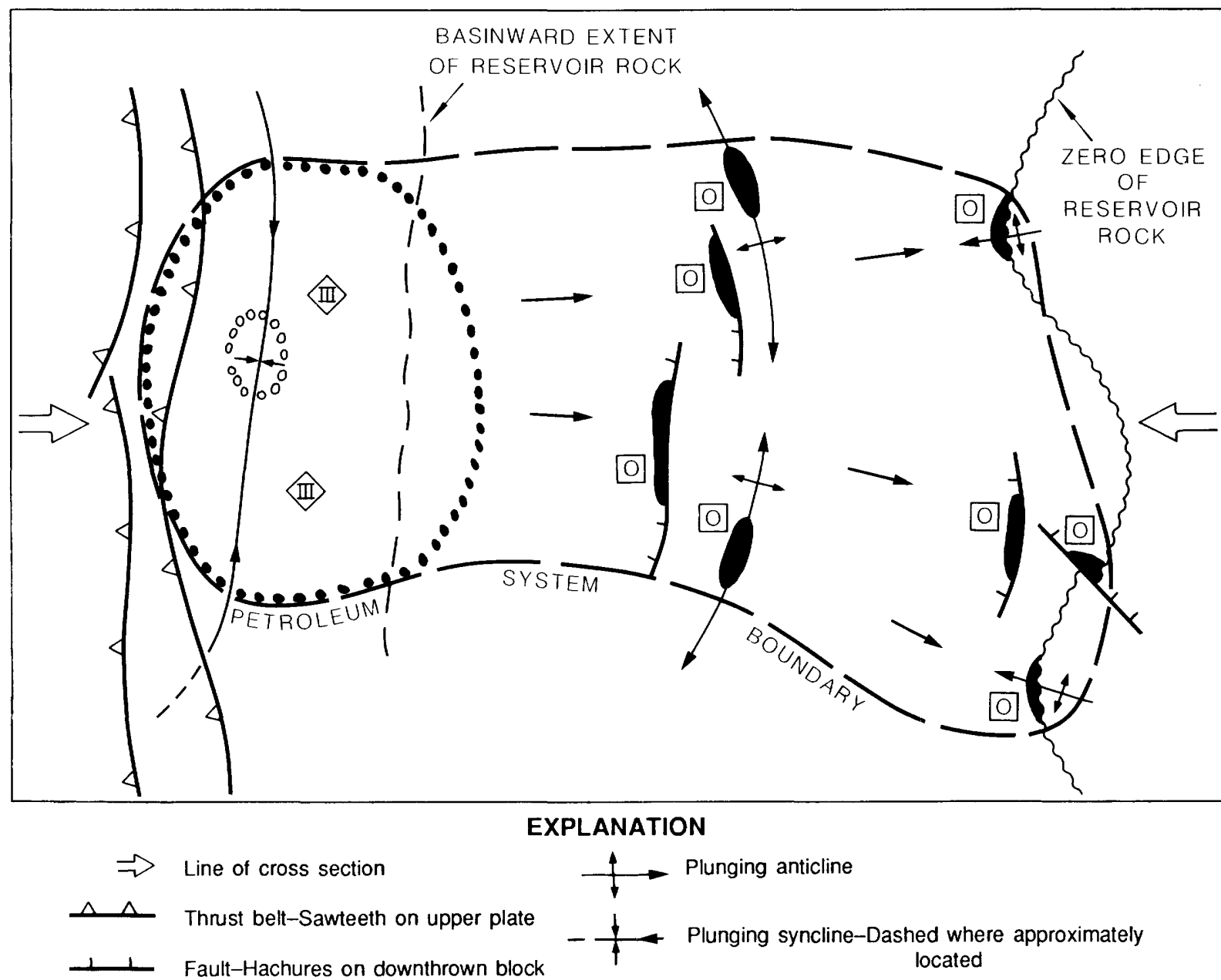

Figure 2. Plan map of the hypothetical basin in figure 1 showing the areal extent of the petroleum system. The boundary circumscribes all petroleum deposits and the mature pod of source rock that generated the hydrocarbons in those deposits. See figure 1 for explanation. 
Table 3. Classification scheme for the petroleum system

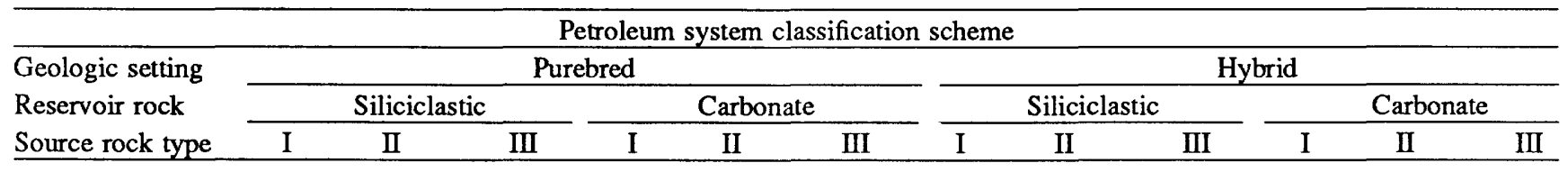

Table 4. One petroleum system in each class and the number of similar systems identified in the United States

\begin{tabular}{|c|c|c|c|c|}
\hline \multicolumn{5}{|c|}{ Petroleum system classification scheme } \\
\hline $\begin{array}{c}\text { Geologic } \\
\text { setting (number) }\end{array}$ & $\begin{array}{c}\text { Reservoir } \\
\text { rock type (number) }\end{array}$ & $\begin{array}{c}\text { Source } \\
\text { rock type }\end{array}$ & $\begin{array}{c}\text { Nomenclature } \\
\text { Source-reservoir (certainty) }\end{array}$ & $\begin{array}{c}\text { Number of } \\
\text { systems }\end{array}$ \\
\hline \multirow[t]{6}{*}{ Purebred (85) } & Siliclastic (56) & I & Green River-Wasatch(.) & 7 \\
\hline & & II & Monterey(!) & 26 \\
\hline & & III & Torok-Nanushuk(.) & 23 \\
\hline & Carbonate (29) & I & Utica-Trenton(!) & 8 \\
\hline & & II & Smackover(!) & 14 \\
\hline & & III & Chattanooga-Fort Payne(.) & 7 \\
\hline \multirow[t]{7}{*}{ Hybrid (34) } & Siliciclastic (27) & I & Sheep Pass-Garrett Ranch(.) & 1 \\
\hline & & II & Ellesmerian(!) & 12 \\
\hline & & III & Tuxedni-Hemlock(.) & 14 \\
\hline & Carbonate (7) & I & None & 0 \\
\hline & & II & Winnipeg-Red River(.) & 7 \\
\hline & & III & None & 0 \\
\hline & & & & Total 119 \\
\hline
\end{tabular}

West

$M$

East

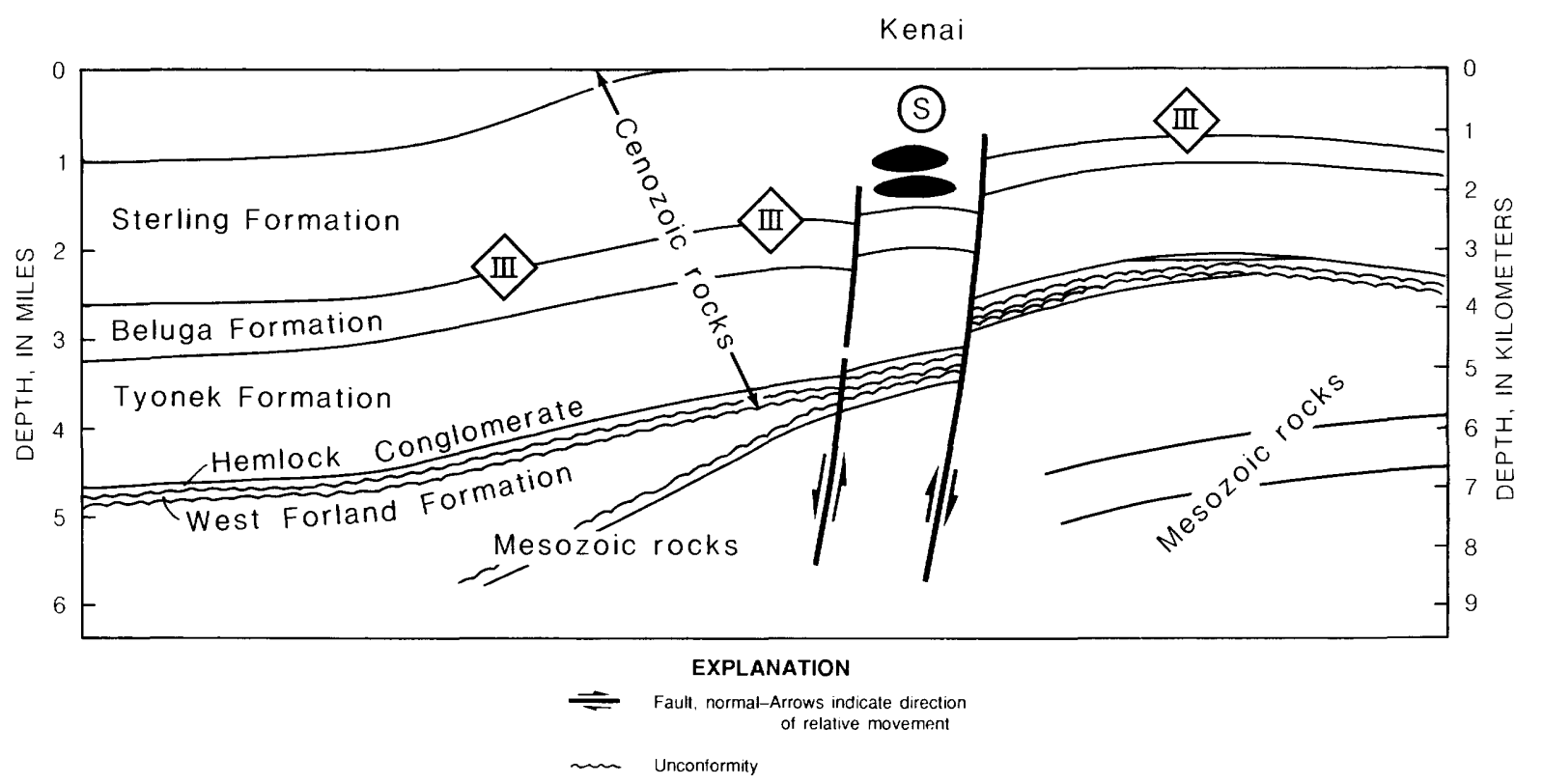

Figure 3. Geologic cross section showing the Beluga-Sterling(.), a purebred petroleum system, in Cook Inlet, Alaska. Section, modified from Boss and others (1976), trends northwest-southeast just north of the Kenai gas field. See figure 1 for explanation. 
0<smiles>C1CCC1</smiles>

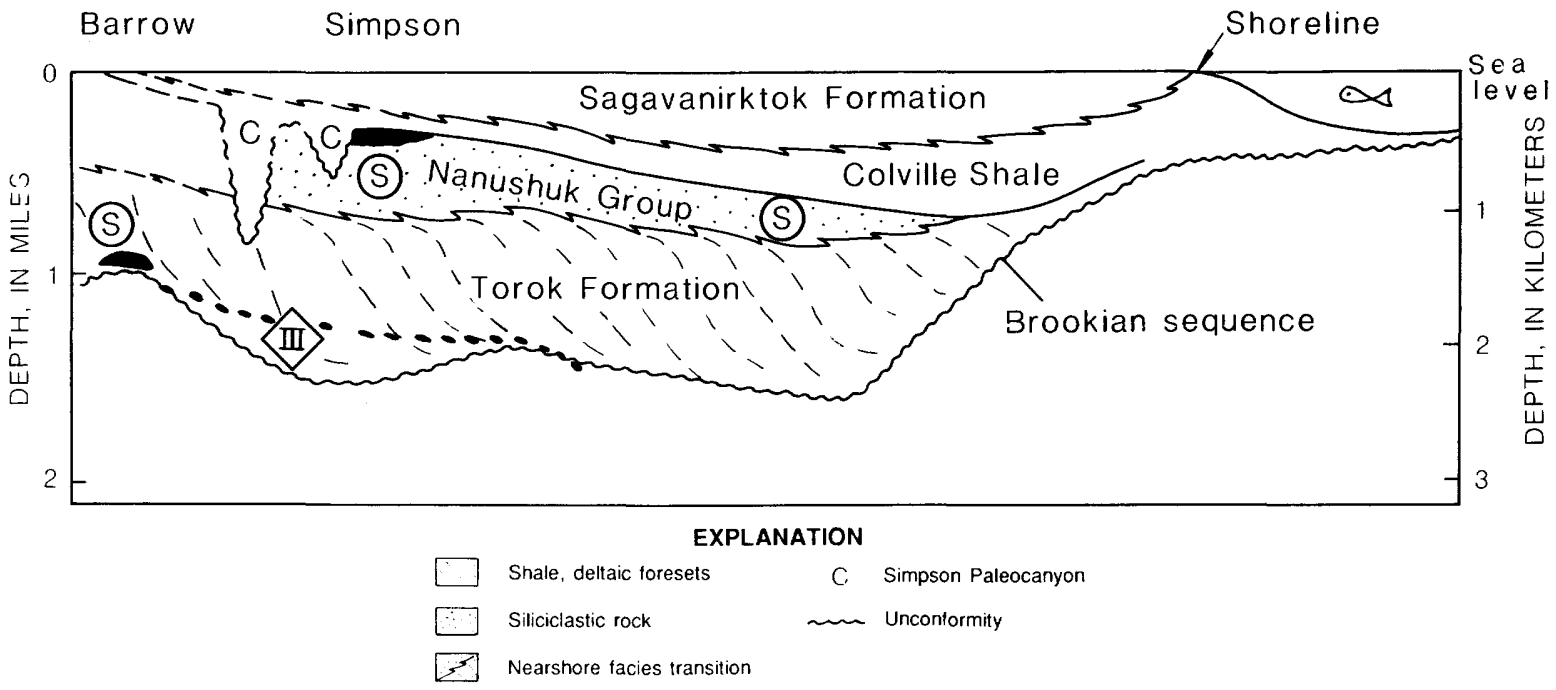

Figure 4. Geologic cross section showing the Torok-Nanushuk(.), a purebred petroleum system on the North Slope of Alaska at end of Cretaceous time. Reservoir rock above the Barrow gas field is a sandstone lens within the pebble shale unit that contained oil (Magoon and Claypool, 1985). Section modified from Bird (1985). See figure 1 for explanation.

West

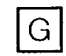

Barrow
E

Dalton

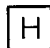

Fish

Creek

$\mathrm{H} \mathrm{O}$

Kuparuk
$0 \quad 0$

Prudhoe Bay

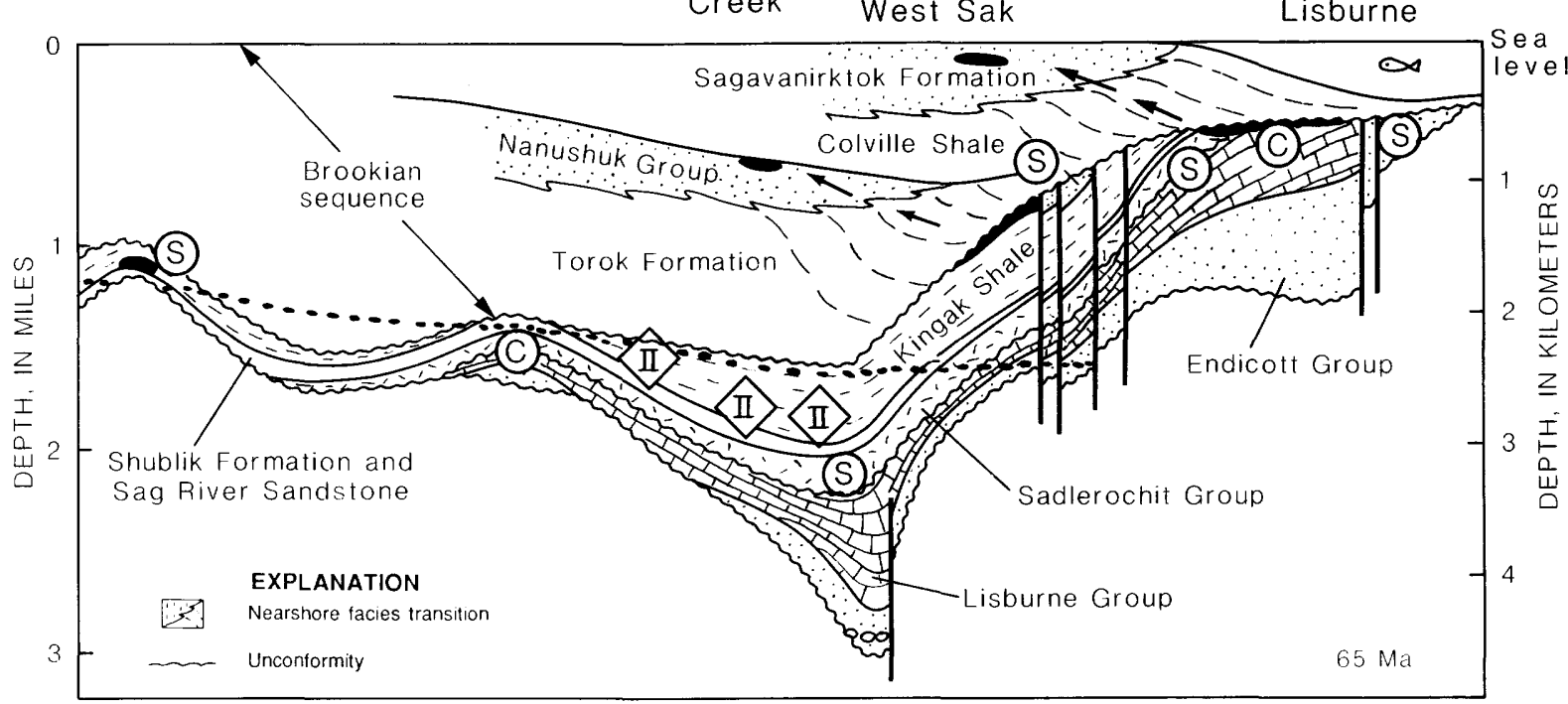

Figure 5. Geologic cross section showing the Ellesmerian(!), a hybrid petroleum system on the North Slope of Alaska at end of Cretaceous time. Section modified from Bird (1985). See figure 1 for explanation.

\section{Petroleum Systems of the United States}


organic matter: the Shublik Formation, Kingak Shale, and to a lesser extent the pebble shale unit (Magoon and Bird, 1985); and three siliciclastic reservoir rocks: the Endicott Group, Sadlerochit Group (Ivishak Formation), and Kuparuk Formation; and a carbonate reservoir, the Lisburne Group (Bird, 1981, 1985). The second setting, a foreland basin, includes rocks deposited by a prograding deltaic deposit that ranges in age from late Early Cretaceous to Holocene and whose primary role in terms of the petroleum system is to provide the overburden necessary to mature the organic matter of the Ellesmerian source rocks. These rock units, derived from the Brooks Range orogen, are designated the Brookian sequence (Lerand, 1973).

This petroleum system is named the Ellesmerian system because the petroleum accumulations originated from at least three source rocks and occurs in four different reservoir rocks; to avoid the cumbersome use of all these stratigraphic units in the name, the single name Ellesmerian is used. The level of certainty is known for the Ellesmerian(!) because an oil-to-source rock correlation has been demonstrated (Seifert and others, 1980; Sedivy and others, 1987). Because two distinctly different depositional sequences are required to form oil in this system, the Ellesmerian(!) is classified as a hybrid petroleum system with siliciclastic reservoirs and type II kerogens (table 4). Even though the Lisburne Group is an important carbonate reservoir, the Ivishak and Kuparuk Formations, siliciclastic reservoirs, are volumetrically the more important reservoirs. The pebble shale unit contains type II/III kerogen, but the two most important oil source rocks, the Shublik Formation and Kingak Shale, contain mostly type II kerogen.

\section{Tuxedni-Hemlock(.)}

In the Cook Inlet, Alaska, several large oil fields occur in reservoirs of Tertiary age (fig. 6). Approximately 80 percent of the oil is reservoired in the Hemlock Conglomerate, a conglomeratic sandstone of Oligocene age (Wolfe, 1981). Two different depositional settings, separated by a major unconformity, were required to complete this petroleum system. The first setting, a marine environment, includes rocks deposited in a forearc basin associated with volcanic and plutonic rocks that range in age from Early Jurassic through Late Cretaceous, and includes both volcaniclastic and siliciclastic rocks. The Middle Jurassic Tuxedni Group, containing a type III kerogen, is considered the source rock for the oil. The second setting, a fluvial environment, includes siliciclastic rocks deposited in a narrow forearc basin trough. These Tertiary rocks include not only the reservoir rock but the overburden necessary to mature the Middle Jurassic source rock. The level of certainty for the Tuxedni-Hemlock(.) petroleum system is hypothetical because geochemical information on the oils and rocks have not demonstrated a correlation (Magoon and Claypool, 1981). This system is classified as a hybrid with siliciclastic reservoirs and type III kerogens.

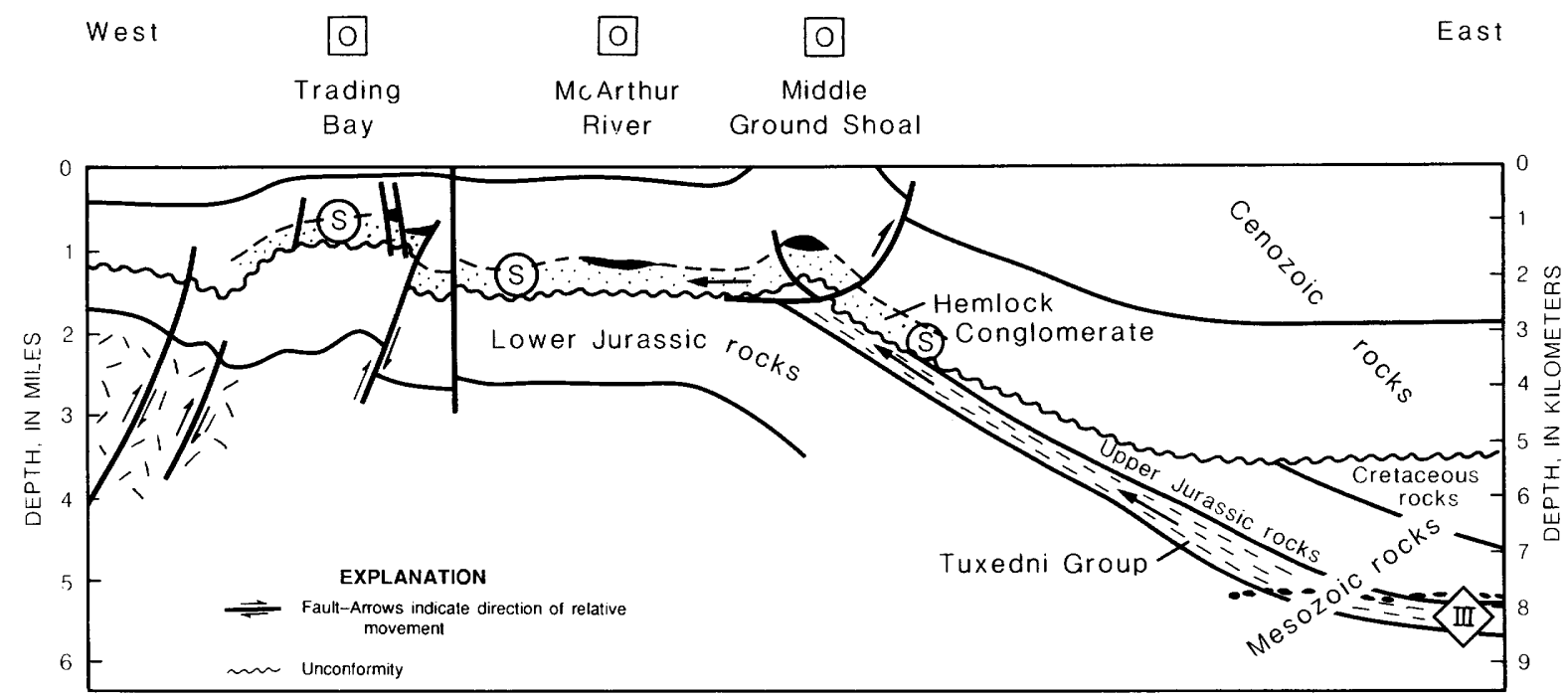

Figure 6. Geologic cross section showing the Tuxedni-Hemlock(.), a hybrid petroleum system in Cook Inlet, Alaska. Section, modified from Boss and others (1976), trends northwest-southeast through the largest oil fields. See figure 1 for explanation. 


\section{SUMMARY}

U.S. Geological Survey geologists recently identified, named, and classified the petroleum systems in the United States during four formal meetings (table 5) and several informal meetings with certain individuals from October 1987 to early February 1988. The results of this initial effort are summarized in tables 4 and 6 .

There are 119 petroleum systems, of which 85 are purebred and 34 are hybrid systems. The most common system is the hybrid, siliciclastic, type II systems, of which there are 26; there are no hybrid, carbonate with either a type I or type III source. Siliciclastic reservoirs (83) occur more than twice as often as carbonate (36) reservoirs. The most common source rock is type II (59), followed by type III (44), with the least common type I (16). In actual practice, the name for each petroleum shown on table 6 was coined from either stratigraphic or time-stratigraphic nomenclature. When more than one name was needed to designate either the source or the reservoir rock, the names were separated with a slash. The predominant petroleum type, either oil or gas, is designated unless the geologist felt that both types were equally important; if one type precedes another, it is felt to be slightly more important. The geographic distribution for each petroleum system is shown as the States covered; if the system is restricted to a basin or area in a large State, the general location is designated.

By classifying the Nation's petroleum systems using the criteria outlined above, the various elements of each system may be scrutinized and compared to determine the mechanism and capacity to generate, migrate, and trap hydrocarbons. Plans call for research projects on selected petroleum systems; the Ellesmerian(!) petroleum system on the North Slope of Alaska will be among the first studied.

\section{REFERENCES CITED}

Ahlbrandt, T.S., ed., 1979, Preliminary geologic, petrologic, and paleontologic results of the study of Nanushuk Group rocks, North Slope, Alaska: U.S. Geological Survey Circular 794, 163 p.

Alaska Oil and Gas Conservation Commission, 1985, 1984 Statistical Report: Anchorage, Alaska Oil and Gas Conservation Commission, $187 \mathrm{p}$.

Bird, K.J., 1981, Petroleum exploration of the North Slope, Alaska, in Mason, J.F., ed., Petroleum geology in China-Principal lectures presented to the United Nations: Tulsa, PennWell Publishing, p. 233-248.

1985, The framework geology of the North Slope of Alaska as related to oil-source rock correlations, in Magoon, L.B. and Claypool, G.E., eds., Alaska North Slope oil/rock correlation study: American Association of Petroleum Geologists Studies in Geology 20, p. 3-29.

1986, A comparison of the play analysis technique as applied in hydrocarbon resource assessments of the National Petroleum Reserve in Alaska and the Arctic National Wildlife Refuge, in Rice, D.D., ed., Oil and gas assessment-Methods and applications: American Association of Petroleum Geologists Studies in Geology 21, p. 133-142.

Bird, K.J., and Magoon, L.B., eds., 1987, Petroleum geology of the northern part of the Arctic National Wildlife Refuge, northeastern Alaska: U.S. Geological Survey Bulletin 1778, 324 p.

Bois, C., 1975, Petroleum-zone concept and the similarity analysis contribution to resource appraisal, in Haun, J.D., ed., Methods of estimating the volume of undiscovered oil and gas resources: American Association of Petroleum Geologists Studies in Geology 1, p. 87-89.

Bois, C., Bouche, P., and Pelet, R., 1982, Global geologic history and distribution of hydrocarbon reserves: American Association of Petroleum Geologists Bulletin, v. 66, no. 9, p. 1248-1270.

Boss, R.F., Lennon, R.B., and Wilson, B.W., 1976, Middle Ground Shoal oil field, Alaska, in Braunstein, Jules, ed., North Amercian oil and gas fields: American Association of Petroleum Geologists Memoir 24, p. 1-22.

Claypool, G.E., and Magoon, L.B., 1985, Comparison of oil-source rock correlation data for Alaskan North Slope: Techniques, results, and conclusions, in Magoon, L.B. and Claypool, G.E., eds., Alaska North Slope oil/rock correlation study: American Association of Petroleum Geologists Special Studies in Geology 20, p. 49-81.

Claypool, G.E., Threlkeld, C.N. and Magoon, L.B., 1980, Biogenic and thermogenic origins of natural gas in Cook Inlet basin, Alaska: American Association of Petroleum Geologists Bulletin, v. 64, p. 1131-1139.

Collins, F.R., and Robinson, R.M., 1967, Subsurface stratigraphic, structural, and economic geology, northern Alaska: U.S. Geological Survey OpenFile report, $171 \mathrm{p}$.

Crick, R.W., 1971, Potential Petroleum Reserves, Cook Inlet, Alaska, in Cram, I.H., ed., Future petroleum provinces of the United States-Their geology and potential: American Association of Petroleum Geologists Memoir 15, v. 1, p. 109-119.

Demaison, G., 1984, The generative basin concept, in Demaison, G. and Murris, R.J., eds., Petroleum 
Table 5. Formal meetings that were required to implement the petroleum system classification scheme $[*$, chaired meetings]

\begin{tabular}{|c|c|c|c|c|}
\hline \multirow{2}{*}{$\begin{array}{l}\text { Meeting } \\
\text { location }\end{array}$} & \multirow{2}{*}{$\begin{array}{c}\text { Date } \\
\text { mo/day/yr }\end{array}$} & \multirow[t]{2}{*}{ Time } & \multicolumn{2}{|c|}{ Geoscientist present } \\
\hline & & & Name & Position \\
\hline \multicolumn{5}{|c|}{ Province: Atlantic Coast; Appalachians; Eastem Interior; Michigan } \\
\hline \multirow[t]{2}{*}{ Reston, Virginia } & $10 / 30 / 87$ & $8: 30 \mathrm{am}-1: 30 \mathrm{pm}$ & $\begin{array}{l}\text { Bayer, Kenneth C. } \\
\text { Gautier, Donald L. }\end{array}$ & $\begin{array}{l}\text { Geophysicist } \\
\text { Geologist }\end{array}$ \\
\hline & & & $\begin{array}{l}\text { Magoon, Leslie B." } \\
\text { Meyer, Richard F. } \\
\text { Roen, John B. } \\
\text { Ryder, Robert T. } \\
\text { deWitt, Wallace } \\
\end{array}$ & $\begin{array}{l}\text { Geologist } \\
\text { Geologist } \\
\text { Geologist } \\
\text { Geologist } \\
\text { Geologist } \\
\end{array}$ \\
\hline \multicolumn{5}{|c|}{ Province: Rocky Mountains; Northern Great Plains; Colorado Plateau; Basin and Range } \\
\hline \multirow[t]{2}{*}{ Denver, Colorado } & $11 / 2 / 87$ & $8: 30 \mathrm{am}-2: 00 \mathrm{pm}$ & $\begin{array}{l}\text { Anders, Donald E. } \\
\text { Butler, William C. } \\
\text { Clayton, Jerry L. } \\
\text { Dolton, Gordon L. } \\
\text { Dyman, Thaddeus S. } \\
\text { Grow, John A. }\end{array}$ & $\begin{array}{l}\text { Chemist } \\
\text { Geologist } \\
\text { Geologist } \\
\text { Geologist } \\
\text { Geologist } \\
\text { Geophysicist }\end{array}$ \\
\hline & & & $\begin{array}{l}\text { Magoon, Leslie B." } \\
\text { Perry, William J. Jr. } \\
\text { Powers, Richard B. } \\
\text { Rice, Dudley D. } \\
\text { Spencer, Charles W. }\end{array}$ & $\begin{array}{l}\text { Geologist } \\
\text { Geologist } \\
\text { Geologist } \\
\text { Geologist } \\
\text { Geologist }\end{array}$ \\
\hline \multicolumn{5}{|c|}{ Province: Atlantic Coast; Gulf Coast; West Texas and eastem New Mexico } \\
\hline \multirow[t]{2}{*}{ Denver, Colorado } & $11 / 3 / 87$ & $8: 30$ am-11:30 am & $\begin{array}{l}\text { Barker, Charles E. } \\
\text { Grow, John A. }\end{array}$ & $\begin{array}{l}\text { Geologist } \\
\text { Geophysicist }\end{array}$ \\
\hline & & & $\begin{array}{l}\text { Magoon, Leslie B.* } \\
\text { Palacas, James G. }\end{array}$ & $\begin{array}{l}\text { Geologist } \\
\text { Geologist }\end{array}$ \\
\hline \multicolumn{5}{|c|}{ Province: Gulf Coast } \\
\hline \multirow[t]{2}{*}{ Corpus Christi, Texas } & $2 / 5 / 88$ & $8: 30 \mathrm{am}-4: 30 \mathrm{pm}$ & Foote, Richard Q. & Geophysicist \\
\hline & & & $\begin{array}{l}\text { Magoon, Leslie B." } \\
\text { Massingill, Linda M. } \\
\text { Wells, Ronnie H. }\end{array}$ & $\begin{array}{l}\text { Geologist } \\
\text { Geologist } \\
\text { Geophysicist } \\
\end{array}$ \\
\hline \multicolumn{5}{|c|}{ Province: Michigan; Mid-continent } \\
\hline \multirow[t]{2}{*}{ Denver, Colorado } & $11 / 4 / 87$ & $8: 30 \mathrm{am}-3: 00 \mathrm{pm}$ & $\begin{array}{l}\text { Charpentier, Ronald R. } \\
\text { Clayton, Jerry L. } \\
\text { Dyman, Thaddeus S. } \\
\text { Grow, John A. } \\
\text { Hatch, Joseph R. } \\
\text { Higley, Debra K. } \\
\text { Law, Benjamin E. }\end{array}$ & $\begin{array}{l}\text { Geologist } \\
\text { Geologist } \\
\text { Geologist } \\
\text { Geophysicist } \\
\text { Geologist } \\
\text { Geologist } \\
\text { Geologist }\end{array}$ \\
\hline & & & $\begin{array}{l}\text { Magoon, Leslie B." } \\
\text { Mast, Richard F. } \\
\text { Schenk, Christopher J. } \\
\text { Schmoker, James W. } \\
\text { Taylor, David J. } \\
\text { Ulmichek, Gregory f. }\end{array}$ & $\begin{array}{l}\text { Geologist } \\
\text { Geologist } \\
\text { Geologist } \\
\text { Geologist } \\
\text { Geologist } \\
\text { Geologist } \\
\end{array}$ \\
\hline & & Province: Alaska & & \\
\hline \multirow[t]{2}{*}{ Menlo Park, California } & $11 / 10 / 87$ & $1: 00 \mathrm{pm}-3: 30 \mathrm{pm}$ & $\begin{array}{l}\text { Bader, Jeffrey W. } \\
\text { Beyer, Larry A. } \\
\text { Bird, Kenneth J. } \\
\text { Collett, Timothy S. } \\
\text { Gautier, Donald L. }\end{array}$ & $\begin{array}{l}\text { Geologist } \\
\text { Geophysicist } \\
\text { Geologist } \\
\text { Geologist } \\
\text { Geologist }\end{array}$ \\
\hline & & & Magoon, Lesile 13. & Geologist \\
\hline & & Province: Pacific Coas & & \\
\hline \multirow[t]{2}{*}{ Menlo Park, California } & $11 / 13 / 87$ & 10:00 am-11:30 am & $\begin{array}{l}\text { Bird, Kenneth J. } \\
\text { Cook, Harry E. } \\
\text { Isaacs, Caroline M. }\end{array}$ & $\begin{array}{l}\text { Geologist } \\
\text { Geologist } \\
\text { Geologist }\end{array}$ \\
\hline & & & $\begin{array}{l}\text { Magoon, Leslie B.* } \\
\text { McLean, Hugh } \\
\text { Stanley, Richard G. } \\
\text { Wagner, Holly }\end{array}$ & $\begin{array}{l}\text { Geologist } \\
\text { Geologist } \\
\text { Geologist } \\
\text { Geologist }\end{array}$ \\
\hline
\end{tabular}


Table 6. Petroleum systems within the United States

[AK, Alaska; AL, Alabama; AR, Arkansas; AZ, Arizona; CA, Califomia; CO, Colorado; CT, Connecticut; FL, Florida; GA, Georgia; IA, Iowa; ID, Idaho; IL, Illinois; IN, Indiana; KS, Kansas; KY, Kentucky; LA, Louisiana; MA; Massachusetts; MI; Michigan; MN, Minnesota; MO, Missouri; MS, Mississippi; MT, Montana; NC, North Carolina; ND, North Dakota; NE, Nebraska; NJ, New Jersey; NM, New Mexico; NV, Nevada; NY, New York; OH, Ohio; OK, Oklahoma; OR, Oregon; PA, Pennsylvania; RI, Rhode Island; SD, South Dakota; TN, Tennessee; TX, Texas; UT, Utah; VA, Virginia; VT, Vermont; WA, Washington; WI, Wisconsin; WV, West Virginia; WY, Wyoming]

\begin{tabular}{lcl}
\hline \multicolumn{1}{c}{ Source-reservoir(certainty) } & Oil/gas & \multicolumn{1}{c}{ State(s) } \\
\hline PUREBRED, siliciclastic reservoir & Type I source & \\
\hline Cabot Head-Medina(.) & Oil & VA,KY,WV,MD,OH,PA,NY \\
Green River-Wasatch(.) & Oil & UT \\
Pennsylvanian cannel coals-sandstone(.) & Oil & TN,KY,VA,WV,OH \\
Austin Chalk/Eagleford-Woodbine(?) & Oil & TX,LA,MS \\
Glenwood-Rose Run(?) & Oil & PA,OH,VA,WV \\
Neogene-Salt Lake(?) & Oil & UT \\
Rose Hill-Keefer(?) & Gas & KY,WV,VA \\
\hline
\end{tabular}

\begin{tabular}{|c|c|c|}
\hline \multicolumn{3}{|c|}{ Type II source } \\
\hline Heath-Tyler(!) & Oil & MT \\
\hline Hue-Sagavanirktok/Canning(!) & Oil & AK \\
\hline Monterey-Puente(!) & Oil & Los Angeles basin, CA \\
\hline Tyler(!) & Oil & ND \\
\hline Conasauga-Rome(.) & Oil & TN,KY,WV,MD,PA \\
\hline Michigan-Stray(.) & Oil/gas & MI \\
\hline Monterey-Repetto/Pico(.) & Oil & Ventura basin, $\mathrm{CA}$ \\
\hline Monterey-Sisquoc(.) & Oil & Santa Maria basin, CA \\
\hline Monterey-Stevens/Kern River(.) & Oil & San Joaquin basin, CA \\
\hline New Albany(.) & Gas & $\mathrm{IN}, \mathrm{IL}, \mathrm{KY}, \mathrm{TN}, \mathrm{MO}$ \\
\hline Tuscaloosa(.) & Gas & TX,LA,AL \\
\hline Woodford-Silurian/Devonian(.) & Oil & NM,TX \\
\hline Aneth/Elbert-McCracken(?) & Oil & AR,CO,NM,UT \\
\hline Curtis-Entrada/Morrison(?) & Oil & $\mathrm{CO}$ \\
\hline Devonian-Berea(?) & Oil & MI \\
\hline Eel River-Rio Dell(?) & Gas & $\mathrm{CA}$ \\
\hline Kreyenhagen-Gatchell(?) & Oil & San Joaquin, CA \\
\hline Lower Cretaceous-Paluxy(?) & Oil/gas & TX,LO,MS,AL,FL,AR,Offshore \\
\hline Miocene(?) & Oil & Offshore CA \\
\hline Monterey(?) & Oil & Point Arena, CA \\
\hline Moreno(?) & Oil & San Joaquin, CA \\
\hline Nonesuch-Keweenawan(?) & Gas & WI,MN,IA,NE,MO,KS \\
\hline Triassic-Newark(?) & Oil & MA,CT,NY,NJ,PA \\
\hline Unkown-Eocene(?) & Oil & $\mathrm{TX}$ \\
\hline Unknown-Eutaw/Selma(?) & Oil & TX,LA,AL,MS \\
\hline Unknown-San Miguel/Olmos(?) & Oil & TX \\
\hline \multicolumn{3}{|c|}{ Type III source } \\
\hline Cretaceous(!) & Gas & MT,ND,SD,WY,NE,CO,KS \\
\hline Devonian Black Shales-Venango(!) & Gas/oil & WV,PA,OH,NY \\
\hline Ohio Shale(!) & Gas & AL,GA,TN,KY,VA,WV,MD,PA,NY,OH \\
\hline Pennsylvanian coals(!) & Gas & AL,GA,TN,KY,VA,WV,MD,OH,PA \\
\hline Pennsylvania-Late Paleozoic(!) & Gas & $\mathrm{OK}, \mathrm{KS}, \mathrm{CO}, \mathrm{AR}, \mathrm{TX}, \mathrm{MO}$ \\
\hline Sunbury-Berea(!) & Oil/gas & KY,OH,WV,VA \\
\hline Antrim(.) & Gas & IN,MI \\
\hline Beluga-Sterling(.) & Gas & $\mathrm{AK}$ \\
\hline Cenozoic(.) & Oil/gas & TX,LA,MS,AL,FL \\
\hline Cretaceous(.) & Gas/oil & Green River basin WY,CO \\
\hline Forbes(.) & Gas & $\mathrm{CA}$ \\
\hline Marcellus-Oriskany(.) & Gas & VA,WV,MD,PA,NY,OH \\
\hline
\end{tabular}

12 Petroleum Systems of the United States 
Table 6. Petroleum systems within the United States-Continued

\begin{tabular}{lcl}
\hline \multicolumn{1}{c}{ Source-reservoir(certainty) } & Oil/gas & \multicolumn{1}{c}{ State(s) } \\
\hline PUREBRED, siliciclastic reservoir & & \\
\hline Miocene(.) & Type III source-Continued & \\
Mississippian coals-sandstones(.) & Gas & MS,AL,FL \\
Starkey-Winters(.) & Gas & VA \\
Stepovak-Bear Lake(.) & Gas & CA \\
Sunbury-Murrysville(.) & Gas & AK \\
Ohio-Big Injun(.) & Gas & PA,WV,OH \\
Chester(?) & Gas/oil & WV,PA,OH \\
Cotton Valley(?) & Gas & MS,AL \\
Hombrook(?) & Gas & TX,LA,MS,FL,AL,AR \\
Jurassic-Cretaceous(?) & Gas & CA,NV \\
Ohio-Weir(?) & Gas & Atlantic offshore \\
\hline
\end{tabular}

PUREBRED, carbonate reservoir

Type I source

\begin{tabular}{|c|c|c|}
\hline Austin Chalk(!) & Oil/gas & TX,LA,MS \\
\hline Simpson-Viola(!) & Oil & $\mathrm{OK}, \mathrm{MO}, \mathrm{KS}$ \\
\hline Trenton(!) & Oil & IN,KY,IL,MO \\
\hline Utica-Trenton(!) & Gas & VT,NY,PA,VA,WV,MD,OH,IN \\
\hline Simpson-Viola/Hunton(.) & Oil & KS,MO,NE,IA \\
\hline Athens-Trenton/Knox(?) & Oil & TN,NC,VA,WV,KY \\
\hline Glenwood-Trempealeau(?) & Gas & $\mathrm{OH}$ \\
\hline Salina-Newburg(?) & Oil & WV,OH \\
\hline \multicolumn{3}{|c|}{ Type II source } \\
\hline Smackover(!) & Oil & TX,LO,MS,AL,FL,AR,Offshore \\
\hline Sunniland(!) & Oil & FL \\
\hline Dollar Bay(.) & Oil & FL \\
\hline Pennsylvanian(.) & Oil & TX,NM \\
\hline Pennsylvanian(.) & Oil & Midland basin,TX \\
\hline Permian(.) & Oil & TX,NM \\
\hline Permian(.) & Oil & \\
\hline Salina-Niagaran(.) & Oil & $\mathrm{MI}, \mathrm{IN}, \mathrm{OH}$ \\
\hline Simpson-Ellenberger/Simpson(.) & Gas/oil & TX,NM \\
\hline Woodford/Chattanooga-Paleozoic(.) & Oil & OK,TX,AR,MO,KS,NE,CO \\
\hline Conasauga-Knox(?) & Oil & MS,AL \\
\hline Devonian-Detroit River/Traverse(?) & Oil & \\
\hline EauClair-Knox(?) & Gas & $\mathrm{IL}, \mathrm{IN}, \mathrm{KY}, \mathrm{MO}$ \\
\hline Ordovician-Prairie du Chien/Black River/Trenton(?) & Oil & WI,MN,IL,IN,OH \\
\hline \multicolumn{3}{|c|}{ Type III source } \\
\hline Chattganooga-Fort Payne(.) & Oil/gas & $\mathrm{KY}, \mathrm{TN}$ \\
\hline Marcellus-Bass Islands(.) & Gas & NY,PA \\
\hline Marcellus-Onondaga(.) & Gas & NY,PA \\
\hline Monroe(?) & Gas & LA \\
\hline Ohio/Chattanooga-Corniferous(?) & Oil/gas & KY \\
\hline Ohio/Sunbury-Greenbriar/Newman(?) & Gas & $\mathrm{VA}, \mathrm{KY}, \mathrm{WV}, \mathrm{OH}, \mathrm{PA}$ \\
\hline Sligo(?) & Gas & TX,LA,AL,MS \\
\hline \multicolumn{3}{|l|}{ HYBRID, siliciclastic reservoir } \\
\hline \multicolumn{3}{|c|}{ Type I source } \\
\hline Sheep Pass-Garrett Ranch(.) & Oil & NV \\
\hline \multicolumn{3}{|c|}{ Type II source } \\
\hline Ellesmerian(!) & Oil & $\mathrm{AK}$ \\
\hline Minnelusa(!) & Oil & WY,NE,SD,CO \\
\hline Phosphoria-Weber(!) & Oil & ID,WY,UT,MT,CO \\
\hline Utica-Beekmantown(!) & Gas & VT \\
\hline
\end{tabular}

A Classification Scheme for Research, Exploration, and Resource Assessment 13 
Table 6. Petroleum systems within the United States-Continued

\begin{tabular}{lcl}
\hline HYBRID, siliciclastic reservoir & Type II source-Continued & \\
\hline Greenhorn-Dakota(.) & Oil & NM,CO \\
Mancos-Mesaverde(.) & Gas & NM,CO \\
Mancos-Tocito(.) & Oil & NM,CO \\
Todilto-Entrada(.) & Oil & NM \\
Aspen/Bear River-Nugget/Madison(?) & Oil & UT,WY \\
Chainman-White Rim(?) & Oil & UT \\
Domengine-Cierbo/Briones(?) & Oil/gas & CA \\
Jurassic/Cretaceous(?) & Oil & MT,ID \\
\hline & Type III source & \\
\hline Cretacous-Tertiary(!) & Gas & Wind River basin WY \\
Lewis-Picture Cliffs(.) & Gas & NM,CO \\
Mesaverde(.) & Gas & Uinta basin UT,CO \\
Mesaverde(.) & Gas & Piceance basin CO \\
Torok-Nanushuk(.) & Oil & AK \\
Tuxedni-Hemlock(.) & Oil & AK \\
Cretaceous(?) & Oil/gas & Big Horn basin WY,MT \\
Cretaceous(?) & Oil & Wind River basin WY \\
Cretaceous(?) & Oil/gas & Denver basin CO,WY,NE \\
Cretaceous(?) & Oil & Powder River basin WY,MT \\
Cretaceous-Tertiary(?) & Gas & Bighorn basin WY \\
Cretaceous(?) & Gas & Laramie basin WY \\
Cretaceous(?) & Gas & North Park basin CO \\
Poul Creek-Katalla(?) & Oil & AK \\
\hline HYBRID, carbonate reservoir & & \\
& Type II source & Oil \\
Bakken-Madison(!) & Oil & MT,SD,ND \\
Winnipeg-Red River(!) & Oil & ND,MT,SD \\
Bakken-Madison(.) & Oil & Sweetgrass arch MT \\
Paradox-Hermosa(.) & Oil & NM,AR,UT,CO \\
Chainman-Simonson(?) & Gas & NV,UT \\
Conasauga-Knox(?) & Oil & VA,TN,NC,GA \\
Favret(?) & & NV \\
\hline
\end{tabular}

geochemistry and basin evaluation: American Association of Petroleum Geologists Memoir 35, p. 1-14.

Dolton, G.L., Bird, K.J., and Crovelli, R.A., 1987, Assessment of in-place oil and gas resources, in Bird, K.J., and Magoon, L.B., eds., Petroleum geology of the northern part of the Arctic National Wildlife Refuge, northeastern Alaska: U.S. Geological Survey Bulletin 1778, p. 277-298.

Dow, W.G., 1974, Application of oil-correlation and source-rock data to exploration in Williston basin: American Association of Petroleum Geologists Bulletin, v. 58, p. 1253-1262.

Hayes, J.B., Harms, J.C., and Wilson, Thomas, Jr., 1976, Contrasts between braided and meandering stream deposits, Beluga and Sterling Formations (Tertiary), Cook Inlet, Alaska, in Miller, T.P., ed., Recent and ancient sedimentary environments in Alaska: Anchorage, Alaska Geological Society, p. J1-J27.

Huffman, A.C., Jr., ed., 1985, Geology of the Nanushuk Group and related rocks, North Slope, Alaska: U.S. Geological Survey Bulletin 1614, p. 129.

Klemme, H.D., 1986, Field size distribution related to basin characteristics, in Rice, D.D., ed., Oil and gas assessment-Methods and applications: American Association of Petroleum Geologists Special Studies in Geology 21, p. 85-99.

Lerand, Monti, 1973, Beaufort Sea, in McCrossan, R.G., ed., The future petroleum provinces of Canada-Their geology and potential: Canadian Society of Petroleum Geologists Memoir 1, p. 315-386.

Magoon, L.B., 1987, The petroleum system-A classification scheme for research, resource assessment and exploration [abs.]: American Association of Petroleum Geologists Bulletin, v.

14 Petroleum Systems of the United States 
71 , no. 5 , p. 587 .

Magoon, L.B., and Bird, 1985, Alaskan North Slope petroleum geochemistry for the Shublik Formation, Kingak Shale, pebble shale unit, and Torok Formation, in Magoon, L.B., and Claypool, G.E., eds., Alaska North Slope oil/rock correlation study: American Association of Petroleum Geologists Studies in Geology 20, p. $31-48$.

Magoon, L.B., and Claypool, L.B., 1981, Petroleum geology of Cook Inlet Basin-An exploration model: American Association of Petroleum Geologists Bulletin, v. 65, no. 6, p. 1043-1061.

Magoon, L.B. and Claypool, G.E., eds., 1985, Alaska North Slope oil/rock correlation study: American Association of Petroleum Geologists Special Studies in Geology 20,678 p.

Magoon, L.B., and Egbert, R.M., 1986, Framework geology and sandstone composition, in Magoon, L.B., ed., Geologic studies of the lower Cook Inlet COST no. 1 well, Alaska outer continental shelf: U.S. Geological Survey Bulletin 1596, p. 65-90.

Meissner, F.F., Woodward, J., and Clayton, J.L., 1984, Stratigraphic relationships and distribution of source rocks in the greater Rocky Mountain region, in Woodward, J., Meissner, F.F., and Clayton, J.L., eds., Hydrocarbon source rocks of the greater Rocky Mountain region: Denver, Rocky Mountain Association of Geologists, p. $1-34$

Molenaar, C.M., 1983, Depositional relations of Cretaceous and lower Tertiary rocks, northeastern Alaska: American Association of Petroleum Geologists Bulletin, v. 67, no. 7, p. 1066-1080.

Molenaar, C.M., Bird, K.J., and Kirk, A.R., 1987, Cretaceous and Tertiary stratigraphy of northeastern Alaska, in Tailleur, I.L., and Weimer, Paul, eds., Alaskan North Slope geology: Bakersfield, Calif., Pacific Section, Society of Economic Paleontologists and Mineralogists and Alaska Geological Society, v. 1, p. 513-528.

Sedivy, R.A., Penfield, I.E., Halpern, H.I., Drozd, R.J.,
Cole, G.A., and Burwood, R., 1987, Investigation of source rock-crude oil relationships in the northern Alaska hydrocarbon habitat, in Tailleur, I.L., and Weimer, Paul, eds., Alaskan North Slope geology: Bakersfield, Calif., Pacific Section, Society of Economic Paleontologists and Mineralogists and Alaska Geological Society, v. 1, p. 169-179.

Seifert, W.K., Moldowan, J.M., and Jones, R.W., 1980, Application of biological marker chemistry to petroleum exploration: Proceedings 10th World Petroleum Congress, v. 2, p. 425-438.

Sluijk, D., and Nederlof, M.H., 1984, Worldwide geological experience as a systematic basis for prospect appraisal, in Demaison, G., and Murris, R.J., eds., Petroleum geochemistry and basin evaluation: American Association of Petroleum Geologists Memoir 35, p. 15-26.

Tissot, B.P., and Welte, D.H., 1984, Petroleum formation and occurrence ( $2 \mathrm{~d}$ ed.): Berlin, Springer-Verlag, $699 \mathrm{p}$.

Ulmishek, Gregory, 1986, Statigraphic aspects of petroleum resource assessment, in Rice, D.D., ed., Oil and gas assessment-Methods and applications: American Association of Petroleum Geologists Studies in Geology 21, p. 59-68.

Welte, D.H., and Yukler, M.A., 1984, Petroleum origin and accumulation in basin evolution-A quantitative model, in Demaison, G., and Murris, R.J., eds., Petroleum geochemistry and basin evaluation: American Association of Petroleum Geologists Memoir 35, p. 27-39.

White, D.A., 1980, Assessing oil and gas plays in facies-cycle wedges: American Association of Petroleum Geologists Bulletin, v. 64, no. 8, p. 1158-1178.

Wolfe, J.A., 1981, A chronologic framework for Cenozoic megafossil floras of northwestern North America and its relation to marine geochronology: Geological Society of America Special Paper 184, p. 39-42.

Zieglar, D.L., and Spotts, J.H., 1978, Reservoir and source-bed history of Great Valley, California: American Association of Petroleum Geologists Bulletin, v. 62 , no. 5, p. 813-826. 


\title{
Role of Amount and Type of Organic Matter in Recognition of Petroleum Source Rocks
}

\author{
By Jerry L. Clayton
}

Source rocks are an essential element of any petroleum system. The purpose of this report is to summarize the current understanding of the roles of amount and type of organic matter in forming source rocks. Concepts of organic maturation are discussed elsewhere in this volume.

Various definitions for petroleum source rock have been proposed (Dow, 1978; Hunt, 1979; Tissot and Welte, 1984; Brooks and others, 1987). In the most general sense, a source rock is any volume of rock that is capable of generating and expelling commercial quantities of oil or gas under proper conditions of heating over geologic time. Hunt (1979) emphasized the need to include "commercial" amounts of hydrocarbons in any source rock definition because nearly all sedimentary rocks can generate small quantities of hydrocarbons. Therefore, as noted by Brooks and others (1987), some ambiguity is inherent in defining a source rock because the criteria include economic considerations, not solely geological criteria. Further, the term "source rock" includes (1) rocks which have not generated hydrocarbons because they have not undergone sufficient heating over geologic time; (2) rocks which are actively generating and expelling hydrocarbons; and (3) rocks which already generated and expelled hydrocarbons during earlier heating and no longer contain residual capacity for further generation on a commercial scale. Source rocks of the first type are often referred to as "potential" source rocks. Rocks of the second and third type are called "effective" source rocks, and the term "spent" source rock (Dow, 1978) is sometimes used to describe the type of effective source rock in the third category. Recognition of source rocks requires characterization of the following criteria: (1) amount of organic matter, (2) type of organic matter, (3) maturity of organic matter, and (4) amount of hydrocarbons generated and expelled.

The amount of organic matter is critical for recognition of a source rock, not only because a minimum total mass of organic matter must be present to generate commercial quantities of hydrocarbons, but also because a minimum threshold concentration of liquid or gaseous organic matter must be present before expulsion (primary migration) of the generated hydrocarbons can occur (Momper, 1978). Ronov (1958) studied a large number of shale samples from petroleum-producing and nonproducing regions and observed that the lower limit for organic carbon content is 0.5 percent (by weight) for shales adjacent to oil-producing fields of part of the Russian Platform. Gehman (1962) investigated carbonate rocks and arrived at an empirically determined minimum value of 0.3 percent for carbonate rocks to be considered as source rocks. Currently, most investigators consider 0.5-1.0 percent as the minimum amount of organic carbon needed for a source rock. For "spent" source rocks, these criteria of minimum organic carbon contents are difficult to apply because much of the original organic carbon may have been lost during generation and expulsion of hydrocarbons, and the residual carbon remaining in the rock may represent only a fraction of the original carbon present. To a large extent, the mass balance approach to source rock evaluation, which is discussed later, avoids the issue of minimum requirement for organic carbon content, because actual amounts of hydrocarbons generated and expelled are calculated.

The type of organic matter present in a source rock is important because different types of organic matter have different potentials for generating hydrocarbons and because the composition of hydrocarbons generated depends on organic matter type. Reservoir rock type usually refers to the depositional site of the rock material, such as nearshore marine; in contrast, source rock type frequently refers to the provenance of the material. For example, a terrestrial source rock, which contains abundant pollen and spores derived from land plants, may be deposited in a marine environment off the mouth of a delta. Source rocks are commonly categorized into marine and nonmarine types. The distinction between marine rock and marine organic matter is important to remember and often tends to be overlooked in discussions of source rock types. A true marine source rock only includes organic matter that originated in a marine environment. However, rocks younger than Ordovician usually contain a mixture of organic matter derived from marine and terrigenous organisms including bacterially reworked material. Nonmarine source rocks contain organic matter derived from terrigenous organisms (higher land plant) or freshwater algae and bacteria. Other environments, such as hypersaline lacustrine and nearshore brackish settings, are also important depositional sites for source rocks. Coals have also been thought to be source rocks for gas, and more recently have been shown to be possible sources of liquid hydrocarbons (Durand and Oudin, 1979;

16 Petroleum Systems of the United States 
Durand and Paratte, 1983; Thompson and others, 1985).

The main organisms contributing to organic matter in source rocks are higher plants, algae, zooplankton, and bacteria. The relative contribution from each of these organisms to a given source rock is important because the chemical composition, and therefore the ultimate hydrocarbon potential, varies among organic components derived from these groups of organisms. In general, higher plant tissue contains biomolecules with more oxygen (cellulose, hemicellulose) and relatively nonbiodegradable components such as lignin. These higher plant biomolecules have a relatively low $\mathrm{H} / \mathrm{C}$ ratio and high $\mathrm{O} / \mathrm{C}$ ratio. Lipids are a minor component of higher plants which reside in leaf cuticles, seeds, and fruits, for example. In contrast, algae and bacteria contain more hydrogen and less oxygen and have a higher lipid content than higher plants. Sedimentary organic matter derived from algae and bacteria has a higher $\mathrm{H} / \mathrm{C}$ ratio and lower $\mathrm{O} / \mathrm{C}$ ratio than higher plant material and, therefore, greater relative capacity for generating liquid hydrocarbons during burial heating.

Lipids, commonly referred to as bitumen in sedimentary rocks, are usually present in secondary amounts in source rocks. Kerogen constitutes most of the organic matter in such rocks. Kerogen is defined by most authors as the organic component of sedimentary rocks that is insoluble in aqueous alkaline and organic solvents. The process by which kerogen is formed from precursor biological materials is not well understood. Although some petroleum hydrocarbons and nonhydrocarbons are derived directly from lipids of living systems having undergone diagenetic alteration, most petroleum constituents are derived from thermal alteration of kerogen. Therefore, the type of organic matter contained in a source rock applies mainly to the kerogen composition.

Kerogen type is classified using organic petrographic and organic geochemical methods. Organic geochemical methods, used widely, can quickly and easily characterize the bulk organic matter (kerogen) in a source rock on a routine basis. Most laboratories use a combination of petrographic and geochemical methods (Magoon and Claypool, 1985). The petrographic approach involves visual identification of individual organic constituents, or macerals, in the organic fraction of a rock. The most common geochemical methods include elemental analysis $(\mathrm{C}, \mathrm{H}, \mathrm{O})$ and pyrolysis. Pyrolysis is the more widely used of the two methods because it is inexpensive on a per-sample cost basis and can be done quickly using only milligram quantities of sample. Figure 7, adapted from Brooks and others (1987), shows a standard van Krevelen diagram with H/C and $\mathrm{O} / \mathrm{C}$ ratios determined from elemental analysis and the equivalent Hydrogen Index and Oxygen Index determined by pyrolysis. Shown also in figure 7 are the different names for kerogen types and the predominant types of products from each kerogen type during catagenesis (petroleum generation).

Another method of characterizing kerogen type is by pyrolysis-gas chromatography (Giraud, 1970; Leventhal, 1976; Larter and Douglas, 1980; Dembicki and others, 1983; Larter, 1984, 1985). This approach to kerogen characterization has some advantages over the visual description and either elemental analysis or pyrolysis estimate of elemental composition because it provides a direct measure of the molecular distribution of hydrocarbons that can be produced by heating a kerogen.

Assessment of the fourth source rock criterion, amount of hydrocarbons generated and expelled, is a goal of the mass balance approach to source rock studies. For example, Larter (1985) defined an "actual" source rock as one "in which hydrocarbon expulsion has occurred to a measurable degree." Mass balance calculations in source rock studies are not new, but have become more popular in recent years and are used increasingly in integrated basin studies. Mass balance calculations using pyrolysis and extraction data were described by Cooles and others (1986) and Mackenzie and Quigley (1988). The method of Cooles and others (1986) is basically the same approach as that used by Merewether and Claypool (1980) with some modifications, most notable of those being consideration of the quantities of free hydrocarbons present in the source rock at both the mature and immature stages of thermal evolution. The principal difficulties with the mass balance approach are (1) the assumption that the mature source rock contains the same type of organic matter (kerogen type) as immature samples of the same rock at other locations in the basin; (2) failure to adequately consider vertical variations in source rock character within the section; (3) errors in measurement of bitumen concentration, either by pyrolysis or solvent extraction (Larter, 1988); and (4) insufficient control on the thickness of the source rock over a broad area under investigation.

Research in source-rock geochemistry in recent years has been directed toward improved understanding of the conditions during sedimentation and early diagenesis that control formation of potential source rocks. The objective of this type of research is to be able to better predict the occurrence of petroleum source rocks. The main factors controlling the accumulation of organic-rich sediments are primary productivity, sedimentation rate, and preservation after burial. However, the various factors influencing each of these stages and the relative importance of each are not yet fully understood. A second area of potentially fruitful research is the application of molecular geochemistry to assess the paleoenvironment of organic-rich rocks. The 
objectives of these types of studies are to understand the specific sources and to follow the diagenetic fate of organic materials in depositional environments (for example, see Brassell and others, 1987). Finally, as pointed out by Larter (1988), additional work is needed to allow better characterization of the molecular composition of organic fractions, especially kerogen and asphaltenes, contained in sedimentary organic matter.

\section{REFERENCES CITED}

Brassell, S.C., Eglinton, C., and Howell, V.J., 1987, Paleoenvironmental assessment of marine organic-rich sediments using molecular organic geochemistry, in Brooks, J., and Fleet, A.J., eds., Marine petroleum source rocks: Boston, Blackwell, p. 79-98.

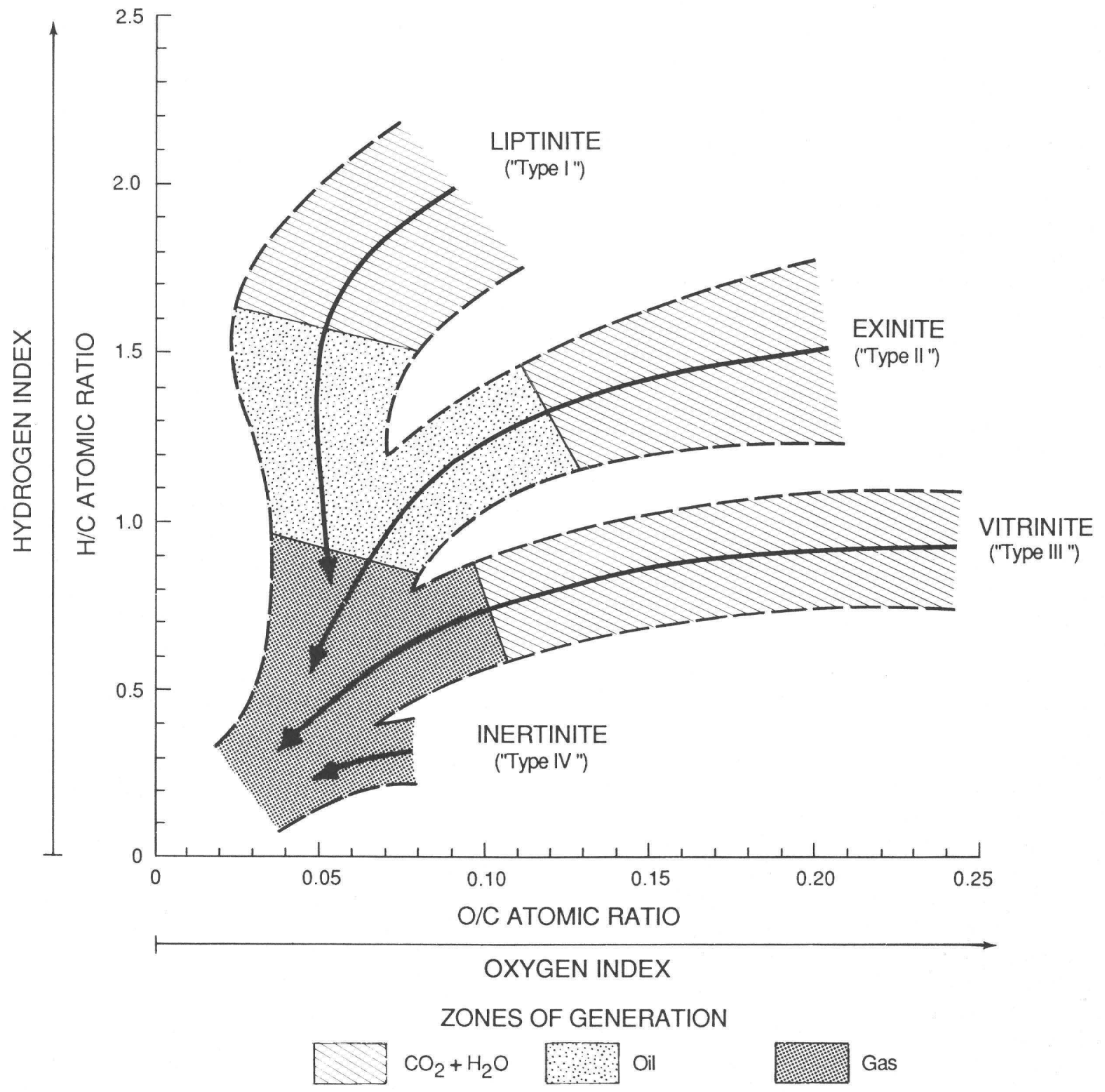

Figure 7. Van Krevelen diagram showing elemental $\mathrm{H} / \mathrm{C}$ and $\mathrm{O} / \mathrm{C}$ for kerogens, and Hydrogen Index and Oxygen Index from Rock-Eval pyrolysis (Espitalié and others, 1985). Arrows show evolution paths for kerogen types during burial heating (modified from Brooks and others, 1987).

18 Petroleum Systems of the United States 
Brooks, J., Cornford, C., and Archer, R., 1987, The role of hydrocarbon source rocks in petroleum exploration, in Brooks, J., and Fleet, A.J., eds., Marine petroleum source rocks: Boston, Blackwell, p. 17-46.

Cooles, G.P., Mackenzie, A.S., and Quigley, T.M., 1986, Calculation of petroleum masses generated and expelled from source rocks, in Leythaeuser, D. and Rullkötter, J., eds., Advances in Organic Geochemistry 1985: Organic Geochemistry, v. 10 , p. 235-245.

Dembicki, H., Horsfield, B., and Ho, T.Y., 1983, Source rock evaluation by pyrolysis-gas chromatography: American Association of Petroleum Geologists Bulletin, v. 67, p. 1094-1103.

Dow, W.G., 1978, Petroleum source-beds on continental slopes and rises: American Association of Petroleum Geologists Bulletin, v. 62, 1584-1606.

Durand, B., and Oudin, J.L., 1979, Exemple de migration des hydrocarbures dans une Sirie deltaoque: Le delta de la Mahakam, Indonisie: 10th World Petroleum Congress Proceedings, v. 2, p. 3-11.

Durand, B., and Paratte, N., 1983, Oil potential of coals: A geochemical approach, in Brooks, J., ed., Petroleum geochemistry and exploration of Europe: Boston, Blackwell, p. 255-265.

Espitalié, J., Deroo, G., and Marquis, F., 1985, Rock-eval pyrolysis and its applications [preprint]: Institut Francais du Pétrole, Rueil, France.

Gehman, H.M., Jr., 1962, Organic matter in limestones: Geochimica et Cosmochimica Acta, v. 26, p. 885-897.

Giraud, A., 1970, Application of pyrolysis and gas chromatography to geochemical characterization of kerogen in sedimentary rocks: American Association of Petroleum Geologists Bulletin, v. 54, p. 439-451.

Hunt, J.M., 1979, Petroleum geochemistry and geology: San Francisco, W.H. Freeman, 617 p.

Larter, S.R., 1984, Application of analytical pyrolysis techniques to kerogen characterization and fossil fuel exploration/utilization, in Voorhees, K. ed., Analytical pyrolysis-Methods and applications: London, Butterworths, p. 212-275. 1985, Improved kerogen typing for petroleum source rock evaluation: Nature, v. 318 , p.

\section{7-280.}

in press, Pragmatic perspectives in petroleum geochemistry: Marine and Petroleum Geology.

Larter, S.R., and Douglas, A.G., 1980, A pyrolysis-gas chromatography method for kerogen typing, in Douglas, A.G. and Maxwell, J.R., eds., Advances in organic geochemistry 1979: New York, Pergamon, p. 579-584.

Leventhal, J.S., 1976, Stepwise pyrolysis-gas chromatography of kerogen in sedimentary rocks: Chemical Geology, v. 18, p. 5-20.

Mackenzie, A.S., and Quigley, T.M., 1988, Principles of geochemical prospect appraisal: American Association of Petroleum Geologists Bulletin, v. 72 , p. 399-415.

Magoon, L.B., and Claypool, G.E., eds., 1985, Alaska North Slope oil/rock correlation study: American Association of Petroleum Geologists Studies in Geology 20, 682 p.

Merewether, E.A., and Claypool, G.E., 1980, Organic composition of some upper Cretaceous shale, Powder River basin, Wyoming: American Association of Petroleum Geologists Bulletin, v. 64, p. 488-500.

Momper, J.A., 1978, Oil migration limitations suggested by geological and geochemical considerations, in Physical and chemical controls on petroleum migration: Tulsa, American Association of Petroleum Geologists Continuing Education Course Note Series, No. 8, p. B1-B60.

Ronov, A.B., 1958, Organic carbon in sedimentary rocks (in relation to presence of petroleum): Translation in Geochemistry, No. 5, p. 510-536.

Tissot, B., and Welte, D.H., 1984, Petroleum formation and occurrence: A new approach to oil and gas exploration: Berlin, Springer-Verlag, 538 p.

Thompson, S., Cooper, B.S., Morley, R.J., and Barnard, P.C., 1985, Oil-generating coals, in Thomas, B.M. and others, eds., Petroleum geochemistry in exploration of the Norwegian shelf: London, Graham and Trotman, p. 59-73.

Van de Meent, D., Brown, S.C., Philp, R.P., and Simoneit, B.R.T., 1980, Pyrolysis-high resolution gas chromatography and pyrolysis gas chromatography-mass spectrometry of kerogens and kerogen precursors: Geochemica et Cosmochimica Acta, v. 44, p. 999-1014. 


\title{
Characteristics of Carbonate Source Rocks of Petroleum
}

\author{
By James G. Palacas
}

Carbonate rocks are unique in that they commonly play a dual role in petroleum systems. Not only can they make good to excellent source rocks but they also make excellent reservoir rocks. Their importance as reservoirs is underscored by the fact that they are host to about 46 percent of the oils in the 509 giant oil fields in the world (Carmalt and St. John, 1986). Another unique feature of carbonate rocks is that in many geologic habitats, contiguous carbonate strata serve both as source and reservoir rock. This synergistic relation is a key factor that distinguishes many carbonate petroleum systems (characterized by inplace oil) in contrast to shale-sandstone systems.

Early workers generally assumed that carbonate rocks were not suitable as source beds of petroleum (von Hettinga Tromp, 1938; Owen, 1964; Hunt, 1967). In contrast, shales were regarded as the primary or perhaps even the only viable petroleum source rock (Andreev and others, 1968; Dott and Reynolds, 1969). Because of this bias, most geologic and geochemical research focused on the role that shale plays in the formation of petroleum. Only limited attention was given to carbonate rocks. However, in the past decade, mounting geologic and geochemical evidence, supported in many cases by oilto-source rock correlations, has proved the efficacy of carbonate and carbonate-evaporite rock types as effective source beds of petroleum. Documentation for such evidence is presented in table 7 .

Table 7. Recent publications in English referring to carbonate and carbonate-evaporite rocks as potential source beds of petroleum

\begin{tabular}{ll}
\hline \multicolumn{1}{c}{ Authors } & Year \\
\hline Milner and others & 1977 \\
Renard and others & 1977 \\
Palacas & 1978 \\
Tissot and others & 1978 \\
Hunt & 1979 \\
& \\
Murris and deGroot & 1979 \\
Malek-Aslani & 1980 \\
Murris & 1980 \\
Ross & 1980 \\
Connan & 1981 \\
Palmer and Zumberge & 1981
\end{tabular}

Table 7. Recent publications in English referring to carbonate and carbonate-evaporite rocks as potential source beds of petroleum - Continued

\begin{tabular}{|c|c|}
\hline Authors & Year \\
\hline Tissot & 1981 \\
\hline Ayres and others & 1982 \\
\hline Connan and others & 1983 \\
\hline Ibe and others & 1983 \\
\hline McKirdy and others & 1983 \\
\hline Rohrback & 1983 \\
\hline Breger & 1984 \\
\hline Burwood & 1984 \\
\hline Connan and others & 1984 \\
\hline Demaison and Bourgeois & 1984 \\
\hline Fu and others & 1984 \\
\hline Gardner and Bray & 1984 \\
\hline Grabowski & 1984 \\
\hline Hughes & 1984 \\
\hline Hunt and McNichol & 1984 \\
\hline Hussler and others & 1984 \\
\hline Jones & 1984 \\
\hline McKirdy and others & 1984 \\
\hline Oehler & 1984 \\
\hline Palacas & 1984 \\
\hline Palacas and others & $1984 a$ \\
\hline Palacas and others & $1984 b$ \\
\hline Patton and others & 1984 \\
\hline Powell & 1984 \\
\hline Rice & 1984 \\
\hline Shinn and others & 1984 \\
\hline Tissot and others & 1984 \\
\hline Tissot and Welte & 1984 \\
\hline Zumberge & 1984 \\
\hline Jones & 1985 \\
\hline Rullkotter and others & 1985 \\
\hline Tannenbaum and Aizenshtat & 1985 \\
\hline Albaiges and others & 1986 \\
\hline Brukner-Wein and Veto & 1986 \\
\hline Connan and others & 1986 \\
\hline Riva and others & 1986 \\
\hline Rullkotter and others & 1986 \\
\hline Talukdar and others & 1986 \\
\hline Chowdhary and Taha & 1987 \\
\hline Sassen and others & 1987 \\
\hline Claypool and Mancini & In press \\
\hline
\end{tabular}


Before proceeding, pertinent source-rock terms need to be defined or clarified. In this report, as gleaned from the literature, carbonate source rocks refer chiefly to fine-grained sedimentary rocks that contain 50 percent or more of carbonate minerals, often associated with variable amounts of argillaceous, siliceous, and evaporitic constituents. Fine-grained limestones such as micrites and lime mudstones are the most prevalent carbonate source rocks, but equivalent dolomite facies also apply. Some lacustrine source deposits designated as "oil shales," such as in the Green River Formation, Uinta basin, are in fact carbonate source beds (Tissot and Welte, 1984, p. 255). Some, if not many, marlstones are also classified as carbonate source beds, especially those that contain more than or close to 50 percent carbonate minerals such as the Alcanar Formation marls of offshore Spain (Demaison and Bourgeois, 1984) and the LaLuna Formation marlstones of Colombia (Zumberge, 1984).

In terms of what constitutes a carbonate or shale source rock, most of the critical factors, such as amounts, type, and maturity of organic matter, are discussed by Clayton (this volume). In general, the amount of organic matter in carbonate rock as well as shale is quite variable and is dependent largely upon the depositional and early diagenetic environment. Jones and Demaison (1982) and Jones (1984) assessed the variability of organic matter content or source potential of sedimentary rocks in terms of the "organic facies" concept. Organic facies is defined as "a mappable rock unit, distinguishable *** by the character of its organic matter without regard to the inorganic aspects of the sediment" (Jones, 1984, p. 163). Jones and Demaison suggested that organic-rich, oilprone organic facies develop in highly anoxic, unbioturbated environments, irrespective of carbonate or clay mineral matrices. Conversely, organic-lean, gasprone organic facies form in oxic, commonly bioturbated environments.

Although Jones (1984) did point out some differences between carbonate and shale source facies, his main focus was on the similarity of characteristics of the source rocks. In this present report, the emphasis is on the uniqueness of many carbonate source rocks in the sense that they commonly generate petroleums with distinctive compositional characteristics. Such carbonate and particularly carbonate-evaporite facies accumulate in saline to hypersaline depositional environments such as lagoons, restricted marine basins, sabkhas, and lacustrine basins. These environments or subenvironments are characterized by low influx of terrigenous debris, high organic productivity in the upper water column, usually anoxic conditions in the lower water column, and always highly reducing conditions beneath the sediment-water interface.

In such highly reducing environments, carbonate-evaporite source facies commonly contain 1-5 percent total organic carbon (TOC) and sometimes as much as 10-30 percent (Palacas, 1984; Powell, 1984; Spiro and others, 1983). Significantly, these same facies, in their thermally immature state $\left(R_{\mathrm{o}}=0.3-0.5\right.$ percent), are characterized by extremely high yields (10-25 percent) of lipid-like extractable organic matter relative to total organic carbon. Moreover, even higher yields (30-80 percent) have been observed in interbeds of these same immature carbonate-evaporite facies (Palacas, 1984; Palmer and Zumberge, 1981, Powell, 1984; Tannenbaum and Aizenshtat, 1985). In sharp contrast, immature shales generally show extract yields of less than 5 percent (Tissot and Welte, 1984, p. 180).

This unusual phenomenon of significant volumes of lipid-like extractable organic matter produced at low levels of thermal maturity runs counter to conventional interpretations that call for maximum generation of liquid petroleum at a much more mature stage of catagenesis. One explanation (Orr, 1986) is that during early diagenesis, in the highly reducing environment where abundant $\mathrm{H}_{2} \mathrm{~S}$ is generated and iron content is low, sulfur becomes incorporated into the kerogen structure (designated as Type II-S kerogen). Cleavage of relatively weak sulfur-carbon bonds results in generation of resin- and asphaltene-rich petroleum at low levels of thermal maturation. Another explanation is that the extreme reducing conditions in the depositional environment cause retardation of the condensation or polymerization of kerogen precursor molecules, resulting in abnormally high ratios of lipid-like soluble organic matter (predominantly resins and asphaltenes) to insolubles (kerogen) (Powell, 1984). Should this latter hypothesis be true, then the resins and asphaltenes, in addition to kerogen, may also serve as major precursors of hydrocarbons generated later under higher thermal stress (Powell and others, 1975; Palacas, 1984). Whatever mechanisms are invoked, the above geological-geochemical phenomena have important implications for petroleum exploration, especially for heavy-oil resources in carbonate regimes.

In order to establish a well-defined petroleum system by correlating oils to oils and oils to source rocks, a comparison of some of the common chemical characteristics of oils believed by various workers to be derived from carbonate (evaporite) and shale source rocks is presented (table 8). The data in the table apply only to oils of comparable maturity and are especially applicable to immature and moderately mature oils. In very mature oils, many of the discrete biomarker components are destroyed or structurally altered. Assumptions are that oils have undergone little or no alteration due to biodegradation, migration, and inreservoir maturation. Obviously, caution should be exercised in using this table because on a worldwide basis there are oils that contain combinations of the two categories of geochemical characteristics listed. Also, some oils may be mixtures of oils derived from two or 
Table 8. Characteristics of low- to medium-maturity oils derived from carbonate versus shale source rocks

[HC, hydrocarbons; Sat, saturated; Arom, aromatic; CPI, carbon preference index; \#, oils derived from lacustrine carbonate rocks are commonly low in sulfur]

\begin{tabular}{|c|c|c|c|}
\hline Parameter & Carbonate rocks & Shales & References \\
\hline API gravity & Low-medium & Medium-high & $6,10,16$ \\
\hline Total sulfur & High (>1 percent)\# & Low ( $<1$ percent) & $1,6,10,12,16$ \\
\hline $\mathrm{HC} /($ resins+asphaltenes $)$ & Low-medium & Medium-high & $1,4,9,10,11,12$ \\
\hline Sat HC/Arom HC & Low-medium & Medium-high & $6,11,12,16$ \\
\hline CPI, $\mathrm{C}_{22}-\mathrm{C}_{32} n$-alkanes & $\leq 1$ & $\geq 1$ & $1,6,10,11,12,17$ \\
\hline Steranes+triterpanes/n-alkanes & High-medium & Low-medium & $1,11,12$ \\
\hline Steranes & $\begin{array}{l}\text { High aquatic to mixed } \\
\text { aquatic/terrestrial } \\
\left(\mathrm{C}_{27}>\mathrm{C}_{29}\right)\end{array}$ & $\begin{array}{l}\text { High terrestrial to mixed } \\
\text { aquatic/terrestrial } \\
\left(\mathrm{C}_{27}<\mathrm{C}_{29}\right)\end{array}$ & 5,6 \\
\hline Diasteranes & Low (-medium) & Medium-high & $6,8,14,15$ \\
\hline Diterpanes: & & & \\
\hline $\mathrm{C}_{24}$ tetracyclic/C $\mathrm{C}_{26}$ tricyclic & High-medium & Medium-low & $2,10,11$ \\
\hline $\begin{array}{l}\mathrm{V} \text { pattern in four isomeric } \\
\text { methyldibenzothiophenes }\end{array}$ & Common & Absent or rare & 6 \\
\hline Thiophenic sulfur & High in benzothiophenes & Low in benzothiophenes & 6 \\
\hline
\end{tabular}

References: (1) Connan, 1981; (2) Connan and others, 1986; (3) Didyk and others, 1978; (4) Grabowski, 1984; (5) Huang and Meinschein, 1979; (6) Hughes, 1984; (7) Hunt and McNicol, 1984; (8) McKirdy and others, 1983; (9) Murris and DeGroot, 1979; (10) Palacas, 1984; (11) Palacas and others, 1984a; (12) Powell, 1984; (13) Renard and others, 1977; (14) Rubenstein and others, 1975; (15) Rullkötter and others, 1985; (16) Tissot and Welte, 1984; (17) Welte and Waples, 1973.

more sources, sometimes of different lithologies. Also, secondary processes may selectively alter the parameters. Therefore, no single parameter can be used to pinpoint the origin of an oil. Rather, interpretation of multiple bulk and molecular parameters is needed to determine oil-source bed relations with some degree of confidence.

\section{REFERENCES CITED}

Albaiges, J., Algaba, J., Clavell, E., and Grimalt, J., 1986, Petroleum geochemistry of the Tarragona Basin (Spanish Mediterranean offshore), in Leythaeuser, D. and Rullkötter, J., eds., Advances in organic geochemistry 1985: Organic Geochemistry, v. 10, p. 441-450.

Andreev, P.F., Bogomolov, A.I., Dobryanskii, A.F., and Kartsev, A.F., 1968, Transformation of petroleum in nature (English translation): Oxford, Pergamon, International Series Monographs in Earth Sciences, v. 29, 466 p.
Ayres, M.G., Bilal, M., Jones, R.W., Slentz, L.W., Tartir, M., and Wilson, A.O., 1982, Hydrocarbon habitat in main producing areas, Saudi Arabia: American Association of Petroleum Geologists Bulletin, v. 66, p. 1-9.

Breger, I.A., 1984, Carbonate sedimentary rocks and the origin of heavy crude oils, in Palacas, J. G., ed., Petroleum geochemistry and source rock potential of carbonate rocks: American Association of Petroleum Geologists Studies in Geology 18, p. 205.

Brukner-Wein, A., and Vetö, I., 1986, Preliminary organic geochemical study of an anoxic Upper Triassic sequence from western Hungary, in Leythaeuser, D. and Rullkötter, J., eds., Advances in organic geochemistry 1985: Organic Geochemistry, v. 10, p. 113-118.

Burwood, R., 1984, Carbonate source rocks for six million barrels of oil per day-Zagros fold belt, southwestern Iran, in Palacas, J.G., ed., Petroleum geochemistry and source rock 
potential of carbonate rocks: American Association of Petroleum Geology Studies in Geology 18, p. 206.

Carmalt, S.W., and St. John, B., 1986, Giant oil and gas fields, in Halbouty, M.T., ed., Future petroleum provinces of the world: American Association of Petroleum Geologists Memoir 40, p. 11-53.

Chowdhary, L.R., and Taha, S., 1987, Geology and habitat of oil in Ras Budran field, Gulf of Suez, Egypt: American Association of Petroleum Geologists Bulletin, v. 71, no. 10, p. 1274-1293.

Claypool, G.E., and Mancini, E.A., in press, Geochemistry of Mesozoic crude oils, gas condensates, and possible source rocks, southwestern Alabama: American Association of Petroleum Geologists Bulletin.

Connan, J., 1981, Biological markers in crude oils, in Mason, J.F., ed., Petroleum geology in China: Tulsa, Pennwell, p. 48-70 and 257-258.

Connan, J., Bouroullec, J., Dessort, D., and Albrecht, P., 1986, The microbial input in carbonateanhydrite facies of a sabkha palaeoenvironment from Guatemala: A molecular approach, in Leythaeuser, D. and Rullkötter, J., eds., Advances in organic geochemistry 1985: Organic Geochemistry, v. 10, p. 29-50.

Connan, J., Hussler, G., and Albrecht, P., 1983, Geochemical properties of crude oils in some carbonate basins: Examples from Tunisia, Iraq and France, in Organic geochemistry applied to oil exploration: OAPEC and IFP Workshop, Paris.

1984, Geochemistry of crude oils and crude oilsource-rock correlations in four carbonate basins, in Palacas, J.G., ed., Petroleum geochemistry and source rock potential of carbonate rocks: American Association of Petroleum Geologists Studies in Geology 18, p. 206.

Demaison, G., and Bourgeois, F.T., 1984, Environment of deposition of middle Miocene (Alcanar) carbonate source beds, Casablanca field, Tarragona Basin, offshore Spain, in Palacas, J.G., ed., Petroleum geochemistry and source rock potential of carbonate rocks: American Association of Petroleum Geologists Studies in Geology 18, p. 151-161.

Didyk, B.M., Simoneit, B.R.T., Brassell, S.C., and Eglington, G., 1978, Organic geochemical indicators of paleoenvironmental conditions of sedimentation: Nature, v. 272, p. 216-222.

Dott, R.H., Jr., and Reynolds, M.J., eds., 1969, Source book for petroleum geology: American Association of Petroleum Geologists Memoir 5, $471 \mathrm{p}$.

Fu Jia Mo, Dai Yong Ding, Liu De Han, and Jia Rong
Fen, 1984, Distribution and origin of hydrocarbons in carbonate rocks (Precambrian to Triassic) in China, in Palacas, J.G., ed., Petroleum geochemistry and source rocks potential of carbonate rocks: American Association of Petroleum Geologists Studies in Geology 18, p. 1-12.

Gardner, W.C., and Bray, E.E., 1984, Oils and source rocks of Niagaran reefs (Silurian) in the Michigan Basin, in Palacas, J.G., ed., Geochemistry and source rock potential of carbonate rocks: American Association of Petroleum Geologists Studies in Geology 18, p. 33-44.

Grabowski, G.J., Jr., 1984, Generation and migration of hydrocarbons in Upper Cretaceous Austin Chalk, southcentral Texas, in Palacas, J.G., ed., Petroleum geochemistry and source rock potential of carbonate rocks: American Association of Petroleum Geologists Studies in Geology 18, p. 97-115.

Huang, W.Y., and Meinschein, W.G., 1979, Sterols as ecological indicators: Geochimica et Cosmochimica Acta, v. 43, p. 739-745.

Hughes, W.B., 1984, Use of thiophenic organosulfur compounds in characterizing crude oils derived from carbonate versus siliciclastic sources, in Palacas, J.G., ed., Petroleum geochemistry and source rock potential of carbonate rocks: American Association of Petroleum Geologists Studies in Geology 18, p. 181-196.

Hunt, J.M., 1967, The origin of petroleum in carbonate rocks, in Chilingar, G.V., Bissel, H.J., and Fairbridge, R.W., eds., Carbonate rocks: New York, Elsevier, p. 225-251.

1979, Petroleum geochemistry and geology: San Francisco, W. H. Freeman, 617 p.

Hunt, J.M., and McNichol, A.P., 1984, The Cretaceous Austin Chalk of South Texas, in Palacas, J. G., ed., Petroleum geochemistry and source rock potential of carbonate rocks: American Association of Petroleum Geologists Studies in Geology 18, p. 117-125.

Hussler, G., Connan, J., and Albrecht, P., 1984, Novel families and tetra- and hexacyclic aromatic hopanoids predominant in carbonate rocks and crude oils, in Schenck, P.A., deLeeuw, J.W., and Lijmbach, G.W.M., eds., Advances in organic geochemistry 1983: Organic Geochemistry, v. 6, p. 39-49.

Ibe, A.C., Ferguson, J., Kinghorn, R.R.F., and Rahman, M., 1983, Organic matter content in carbonate sediments in relation to petroleum occurrence: Journal of Petroleum Geology, v. 6, no. 1, p. 55-70.

Jones, R.W., 1984, Comparison of carbonate and shale 
source rocks, in Palacas, J. G., ed., Petroleum geochemistry and source rock potential of carbonate rocks: American Association of Petroleum Geologists Studies in Geology 18, p. 163-180.

1985, Hydrocarbon habitat in main producing areas, Saudi Arabia: Reply: American Association of Petroleum Geologists Bulletin, v. 69 , no. 11 , p. 2031-2033.

Jones, R.W., and Demaison, G.J., 1982, Organic facies-Stratigraphic concept and exploration tool, in Saldivar-Sali, A., ed., Proceedings of the Second Asian Council on Petroleum Conference and Exhibition, 1981: Manila, Asian Council on Petroleum, p. 51-68.

Malek-Aslani, M., 1980, Environmental and diagenetic controls of carbonate and evaporite source rocks: Gulf Coast Association of Geological Societies Transactions, v. 30, p. 445-458.

McKirdy, D.M., Aldridge, A.K., and Ypma, P.J.M., 1983, A geochemical comparison of some crude oils from pre-Ordovician carbonate rocks, in Bjoroy, M., and others., eds., Advances in organic geochemistry 1981: Chichester, John Wiley \& Sons, p. 99-107.

McKirdy, D.M., Kantsler, A.J., Emmett, J.K., and Aldridge, A.K., 1984, Hydrocarbon genesis and organic facies in Cambrian carbonates of the Eastern Officer Basin, South Australia, in Palacas, J.G., ed., Petroleum geochemistry and source rock potential of carbonate rocks: American Association of Petroleum Geologists Studies in Geology 18, p. 13-31.

Milner, C.W.D., Rogers, M.A., and Evans, C.R., 1977, Petroleum transformations in reservoirs: Journal of Geochemical Exploration, v. 7, p. 101-153.

Murris, R.J., 1980, Middle East: Stratigraphic evolution and oil habitat: American Association of Petroleum Geologists Bulletin, v. 64, p. 597-618.

Murris, R.J., and de Groot, K., 1979, Oil habitat of carbonate provinces: Congreso Panamericano de Ingenieri a Petroleo, Mexico, Proceedings, sec. 1, paper 5 .

Oehler, J.H., 1984, Carbonate source rocks in the Jurassic Smackover trend of Mississippi, Alabama, and Florida, in Palacas, J.G., ed., Petroleum geochemistry and source rock potential of carbonate rocks: American Association of Petroleum Geologists Studies in Geology 18, p. 63-69.

Orr, W.L., 1986, Kerogen/asphaltene/sulfur relationships in sulfur-rich Monterey oils, in Leythaeuser, D., and Rullkötter, J., eds., Advances in organic geochemistry 1985: Organic Geochemistry, v. 10, p. 499-516.
Owen, E.W., 1964, Petroleum in carbonate rocks: American Association of Petroleum Geologists Bulletin, v. 45, p. 1727-1730.

Palacas, J.G., 1978, Preliminary assessment of organic carbon content and petroleum source rock potential of Cretaceous and lower Tertiary carbonates, South Florida Basin: Gulf Coast Association of Geological Societies Transactions, v. 28, p. 357-381.

1984, Carbonate rocks as sources of petroleum: Geological and chemical characteristics and oilsource correlations: 11th World Petroleum Congress Proceedings, 1983, London, v. 2, p. $31-43$.

Palacas, J.G., Anders, D.E., and King, J.D., 1984a, South Florida Basin-Prime example of carbonate source rocks of petroleum, in Palacas, J. G., ed., Petroleum geochemistry and source rock potential of carbonate rocks: American Association of Petroleum Geologists Studies in Geology 18, p. 71-96.

Palacas, J.G., King, J.D., Claypool, G.E., and Magoon, L.B., 1984b, Origin of asphalt and adjacent oil stains in Lower Cretaceous fractured limestones, Deep Sea Drilling Project Leg 77, in Buffler, R.T., Schlager, W., and others, eds., Initial reports of the deep sea drilling project 77: Washington, U.S. Government Printing Office, p. 477-488.

Palmer, S.E., and Zumberge, J.E., 1981, Organic geochemistry of Upper Miocene evaporite deposits in the Sicilian Basin, Sicily, in Brooks, J., ed., Organic maturation studies and fossil fuel exploration: London, Academic Press, p. 393-426.

Patton, J.W., Choquette, P.W., Guennel, G.K., Kaltenback, A.J., and Moore, A., 1984, Organic geochemistry and sedimentology of Lower to mid-Cretaceous deep-sea carbonates, sites 535 and 540, Leg 77, in Buffler, R.T., Schlager, W., and others, eds., Initial Reports of the Deep Sea Drilling Project 77: Washington, U.S. Government Printing Office, p. 417-443.

Powell, T.G., 1984, Some aspects of the hydrocarbon geochemistry of a Middle Devonian barrier-reef complex, Western Canada, in Palacas, J.G., ed., Petroleum geochemistry and source rock potential of carbonate rocks: American Association of Petroleum Geologists Studies in Geology 18, p. 45-61.

Powell, T.G., Cook, P.J., and McKirdy, D.M., 1975, Organic geochemistry of phosphorites: Relevance to petroleum genesis: American Association of Petroleum Geologists Bulletin, v. 59 , p. 618-632.

Renard, B., Du Rouchet, J., and Connan, J., 1977, Les 
roches-mères carbonatées, in Essai de caractérisation sédimentologique des dépôts carbonatés, 2: Eléments d'interprétation: Boussens et Pau, Elf Aquitaine, p. 139-149.

Rice, D.D., 1984, Occurrence of indigenous biogenic gas in organic-rich, immature chalks of late Cretaceous age, Eastern Denver Basin, in Palacas, J.G., ed., Petroleum geochemistry and source rock potential of carbonate rocks: American Association of Petroleum Geologists Studies in Geology 18, p. 135-150.

Riva, A., Salvatori, T., Cavaliere, R., Ricchiuto, T., and Novelli, L., 1986, Origin of oils in Po Basin, Northern Italy, in Leythaeuser, D. and Rullkötter, J., eds., Advances in organic geochemistry 1985: Organic Geochemistry, v. 10 , p. 391-400.

Rohrback, B.G., 1983, Crude oil geochemistry of the Gulf of Suez, in Bjoroy, M., and others, eds., Advances in organic geochemistry 1981: Chichester, John Wiley \& Sons, p. 39-48.

Ross, L.M., 1980, Geochemical correlations of San Juan basin oils-A study: Oil and Gas Journal, v. 78, no. 44 , p. $102-110$.

Rubenstein, I., Sieskind, O., and Albrecht, P., 1975, Rearranged sterenes in shale: Occurrence and simulated formation: Journal Chemical Society Perkin Transactions, v. 1, p. 1833-1836.

Rullkötter, J., Myers, P.A., Schaefer, R.G., and Dunham, K.W., 1986, Oil generation in the Michigan basin: A biological marker and carbon isotope approach, in Leythaeuser, D., and Rullkötter, J., eds., Advances in organic geochemistry 1985: Organic Geochemistry, v. 10, p. 359-375.

Rullkötter, J., Spiro, B., and Nissenbaum, A., 1985, Biological marker characteristics of oils and asphalts from carbonate source rocks in a rapidly subsiding graben, Dead Sea, Israel: Geochimica et Cosmochimica Acta, v. 49, p. 1357-1370.

Sassen, R., Moore, C.H., and Meendsen, F.C., 1987, Distribution of hydrocarbon source potential in the Jurassic Smackover Formation: Organic Geochemistry, v. 11 , no. 5, p. 379-383.

Shinn, E.A., Robbin, D.M., and Claypool, G.E., 1984, Compaction of modern carbonate sediments: Implications for generation and expulsion of hydrocarbons, in Palacas, J.G., ed., Petroleum geochemistry and source rock potential of carbonate rocks: American Association of Petroleum Geologists Studies in Geology 18, p. 197-203.
Spiro, B., Welte, D.H., Rullkötter, J., and Schaeffer, R.G., 1983, Asphalts, oils, and bituminous rocks from the Dead Sea area-A geochemical correlation study: American Association of Petroleum Geologists Bulletin, v. 67, no. 7, p. 1163-1175.

Talukdar, S., Gallango, O., and Chin-A-Lien, M., 1986, Generation and migration of hydrocarbons in the Maracaibo Basin, Venezuela: An integrated basin study, in Leythaeuser, D., and Rullkötter, J., eds., Advances in organic geochemistry 1985: Organic Geochemistry, v. 10, p. 261-279.

Tannenbaum, G., and Aizenshtat, Z., 1985, Formation of immature asphalt from organic-rich carbonate rocks-I. Geochemical correlation: Organic Geochemistry, v. 8, no. 2, p. 181-192.

Tissot, B., 1981, Generation of petroleum in carbonate rocks and shales of marine or lacustrine facies and its geochemical characteristics, in Mason, J.F., ed., Petroleum geology in China: Tulsa, Pennwell, p. 71-82.

Tissot, B., Deroo, G., and Hood, A., 1978, Geochemical study of the Uinta Basin: Formation of petroleum from the Green River Formation: Geochimica et Cosmochimica Acta, v. 42, p. 1469-1485.

Tissot, B., Pelet, R., Furollet, B.B., and Oudin, J.L., 1984, Recurrent appearance of source-rock facies in Cretaceous to Eocene carbonate series of Tunisia, in Palacas, J.G., ed., Petroleum geochemistry and source rock potential of carbonate rocks: American Association of Petroleum Geologists Studies in Geology 18, p. 205.

Tissot, B.P., and Welte, D.H., 1984, Petroleum formation and occurrence: Berlin, Springer-Verlag, $538 \mathrm{p}$.

Von Hettinga Tromp, Ir. H., 1938, Petroleum cannot be generated in limestones: Second World Petroleum Congress Proceedings 1937, Paris, p. 371-381.

Welte, D.H., and Waples, D., 1973, Ober die Bevorzugung geradzahliger n-Alkane in sedimentgesteinen: Naturwissenschaften, v. 60 , p. 516-517.

Zumberge, J.E., 1984, Source rocks of the LaLuna Formation (Upper Cretaceous) in the Middle Magdalena Valley, Colombia, in Palacas, J.G., ed., Petroleum geochemistry and source rock potential of carbonate rocks: American Association of Petroleum Geologists Studies in Geology 18, p. 127-133. 


\title{
Geothermics of Petroleum Systems: Implications of the stabilization of Kerogen Thermal Maturation after a Geologically Brief Heating Duration at Peak Temperature
}

\author{
By Charles E. Barker
}

\section{INTRODUCTION}

Although the degree of interplay between temperature and time in the thermal maturation of source rocks is controversial, it is now established that heating of kerogen, usually by burial, is crucial to generate petroleum (Naeser and McCulloch, 1988). Evidence is also accumulating that kerogen thermal maturation stabilizes (terminates) after a geologically short reaction time at maximum temperature (Robert, 1980; Barker, 1983; Price, 1983; Kisch, 1987; and others). Geologic time at peak temperature is almost always sufficient to allow stabilization of the maturation process (Suggate, 1982), requiring 1 to 10 million years (m.y.) during burial diagenesis (Kisch, 1987; Barker, 1988). The stabilization of kerogen thermal maturation implies some important new concepts that apply to petroleum systems.

Firstly, it should be possible to assess sourcerock thermal maturity by considering temperature alone rather than temperature and time together. Most petroleum generation occurs during catagenesis, commencing at about $50{ }^{\circ} \mathrm{C}$ and finishing at the threshold of dry gas generation at about $200{ }^{\circ} \mathrm{C}$ (Hunt, 1979, p. 102; Ammosov, 1981; and others). Secondly, petroleum generation may cease after a geologically brief time at peak temperature. Lastly, overpressured or hydrothermal fluids associated with increasing temperature during burial are a crucial element in a petroleum system. Migration of petroleum in these hot, reactive fluids may cause enhanced porosity in the reservoir rock, or interact with rocks just above the path to form reservoir seals. This last point extends from the influence of increasing temperature on the petroleum system, inducing forced convection with simultaneous petroleum migration, along with diagenetic changes caused by the turnover of pore fluids (Wood and Hewett, 1985), and influencing the porosity (Schmoker, 1984) remaining in the potential reservoir rocks and seals. Because diagenetic reactions and the rate of convection are enhanced by increased temperature, the most profound changes are likely at near peak temperature. These factors make the timing and magnitude of peak temperature (the thermal history) important in determining the hydrocarbon volume, where and when traps form, the proportion of oil to gas, and apparently, when petroleum ceases to be generated in the system.

As a consequence of the stabilization of thermal maturation, vitrinite reflectance $\left(R_{o}\right)$, an index of thermal maturity, can be calibrated empirically to the peak temperature. A series of $R_{o}$ measurements taken at various levels in sedimentary sections can be used to compute a profile consisting of peak temperature points, within some constraints (Dembicki, 1984; Barker and Pawlewicz, 1986). The peak temperature profile is a crucial reference line for thermal history reconstruction by comparative geothermometry. The thermal history of the sedimentary section, within some limitations, can be inferred by comparing mineral-based geothermometric data and the present-day temperature profile (Gretener, 1981, p. 13) to the peak temperature profile. Application of this technique by the U.S. Geological Survey to selected petroleum systems illustrates how peak temperature and thermal history are interpreted.

\section{PEAK TEMPERATURE}

\section{Delaware basin, Texas}

Barker and Halley (1986) studied paleotemperatures indicated by fluid inclusion, $R_{o}$, and oxygen isotope data from fracture-filling calcite and host rock in the Bone Spring Limestone (Leonardian), Delaware basin, Texas. Although the cements have petrographically distinct multiple zones, homogenization temperatures $\left(T_{h}\right)$ of oil inclusions, $\delta^{18} \mathrm{O}$ data, and in some samples crosscutting relationships, divide these cements into the early and late groups. Early cements have $\delta^{18} \mathrm{O}$ near zero permil and contain blue fluorescent oil inclusions whose mean $T_{h}$ is $70^{\circ} \mathrm{C}\left(160^{\circ} \mathrm{F}\right)$. The late cements have $\delta^{18} \mathrm{O}$ of about -9 permil and contain sparse oil inclusions with blue fluorescence similar to those in the early cement. Crosscutting both these cements is a later generation of oil fluid inclusions with a yellow fluorescence. Primary fluid inclusions in the late cements have a mean $\mathrm{T}_{h}$ of $110^{\circ} \mathrm{C}\left(230^{\circ} \mathrm{F}\right)$. The mean $\mathrm{T}_{h}$ of these inclusions is comparable to the $110{ }^{\circ} \mathrm{C}$ calculated from $\mathrm{a}_{\mathrm{o}}$ of 0.7 percent with the Barker and Pawlewicz 
(1986; modified as noted below) empirical calibration and the $45^{\circ} \mathrm{C}\left(80^{\circ} \mathrm{F}\right)$ temperature change from the early to late cement interpreted from a $\delta^{18} \mathrm{O}$ difference of about 9 permil. These thermal data and burial history reconstruction suggest that both the late cements and $R_{o}$ record the maximum temperature attained in the rock. These temperatures suggest a geothermal gradient of at least $40{ }^{\circ} \mathrm{C} / \mathrm{km}\left(2.2^{\circ} \mathrm{F} / 100 \mathrm{ft}\right)$ higher than previously reported for the western Delaware basin (Kinney, 1976)*. Barker and Pawlewicz (1987) extended Barker and Halley's study to Leonardian rocks throughout the Delaware basin. Their $R_{0}$ data suggested that the Leonardian petroleum system in the western portion of the basin was hotter than that in the eastern portion. This heating is attributed to igneous intrusions and increased heat flow related to the mid-Tertiary development of the Basin and Range Province in the western Delaware basin. Burial history reconstruction indicates that oil was generated during near-maximum burial in Permian time with a geothermal gradient of about $25{ }^{\circ} \mathrm{C} / \mathrm{km}(1.4$ ${ }^{\circ} \mathrm{F} / 100 \mathrm{ft}$ ). Peak temperatures computed from $\mathrm{R}_{\mathrm{o}}$-depth relationships and Barker and Pawlewicz's (1986) modified empirical geothermometer imply that paleogeothermal gradients exceeded $40{ }^{\circ} \mathrm{C} / \mathrm{km} \quad(2.2$ ${ }^{\circ} \mathrm{F} / 100 \mathrm{ft}$ ) in Tertiary time. This reheating produced thermally mature rocks as young as Guadalupian in the western Delaware basin and caused a second episode of petroleum generation in the Leonardian petroleum system. Evidence that each thermal event caused renewed petroleum migration includes distinct fracture sets that have trapped at least two oils with different fluorescence colors.

\section{Green River basin, Wyoming}

Pollastro and Barker (1986) used comparative geothermometry to study the Cretaceous(.) petroleum system penetrated by a deep borehole through the Pinedale anticline, northern Green River basin, Wyoming. Using the modified Barker and Pawlewicz (1986) empirical calibration, they computed peak temperature in the petroleum system of about $200{ }^{\circ} \mathrm{C}$ $\left(390^{\circ} \mathrm{F}\right)$, close to the temperature calculated from claymineral data at about $190{ }^{\circ} \mathrm{C}\left(370{ }^{\circ} \mathrm{F}\right)$. Uncorrected borehole temperature is now about $130^{\circ} \mathrm{C}\left(270^{\circ} \mathrm{F}\right)$. The

* We now think it is better to use a regression method that allows error to be present in both the independent and dependent variable. The major axis regression method (Till, 1974) calculates the following equation from the same set of $R_{0}$ and temperature data: $\ln \left(R_{0}\right)=$ $0.0096(T \max )$ - 1.4. This equation produces peak temperature predictions $\left(T_{\max }\right)$ from $R_{o}$ that are more compatible with other geothermometers and burial history reconstruction. slope of the present-day borehole temperature measurements and the slope of temperatures interpreted from $R_{o}$ are about $25^{\circ} \mathrm{C} / \mathrm{km}\left(1.4{ }^{\circ} \mathrm{F} / 100 \mathrm{ft}\right)$. Fluid inclusion homogenization temperatures in quartz-filled fractures formed by late Tertiary deformation are equal to present-day temperature. An extrapolated $R_{0}$ surface intercept of 0.33 percent indicates that about $1,700 \mathrm{~m}$ $(5,600 \mathrm{ft})$ of section has been removed. Decreasing the burial depth by $1,700 \mathrm{~m}$ in a geothermal gradient of 25 ${ }^{\circ} \mathrm{C} / \mathrm{km}$ would decrease borehole temperatures by about $40^{\circ} \mathrm{C}\left(70^{\circ} \mathrm{F}\right)$, making it consistent with the other geothermometric data. These data were interpreted to indicate that the temperature decrease of about $40^{\circ} \mathrm{C}(70$ ${ }^{\circ} \mathrm{F}$ ) was caused by uplift and erosion rather than by decline in geothermal gradient, which occurred before the fractures were filled with quartz. A subsequent fission-track annealing study in this same borehole confirmed a temperature decline of at least $20^{\circ} \mathrm{C}\left(40^{\circ} \mathrm{F}\right)$ at approximately $3 \mathrm{Ma}$ (Naeser, 1984).

\section{Piceance basin, Colorado}

Law and others (in press) studied the Mesaverde(.) petroleum system in the Piceance basin, Colorado. Here segmented $R_{0}$ profiles are interpreted to result from heating caused by relatively warm fluids displaced upward when gas filled the pores of overpressured rocks. Barker (in press) used their vitrinite reflectance data to compute peak temperature of at least $200{ }^{\circ} \mathrm{C}\left(390{ }^{\circ} \mathrm{F}\right)$ in the Cameo coal zone. This peak temperature is higher than that expected $\left(175^{\circ} \mathrm{C} ; 350^{\circ} \mathrm{F}\right)$ from extrapolating the present-day temperature profile (heat flow has not changed since the Paleozoic) to the reconstructed maximum burial depth of the Cameo coal zone. Barker (in press) suggested that the decrease of thermal conductivity caused by gas (rather than water) filling the pores of a rock can temporarily increase geothermal gradients to twice the ambient geothermal gradient, without changing the heat flow in the rock section. The decreased thermal conductivity suggests a peak temperature (using the method of Gretener, 1981) similar to that computed from $\mathrm{R}_{\mathrm{o}}$ using the modified Barker and Pawlewicz (1986) equation.

\section{SUMMARY}

New evidence that thermal maturation stabilizes after a geologically brief time at peak temperature has important implications in the study of petroleum systems. Thermal maturation and petroleum generation may cease soon after peak temperature is reached. Consequently, the peak temperature is most influential in determining $R_{o}$, a measure of thermal maturity. The comparative 
geothermometry technique, which utilizes $R_{0}$ as a maximum recording geothermometer, together with supporting geological evidence, can produce a thermal history reconstruction of a petroleum system. Application of this technique shows that many petroleum systems are buried quickly and rapidly reach temperatures sufficient for petroleum generation. Many also remain near maximum burial for extended periods of geologic time. In some cases, heating events at or after maximum burial have produced another episode of petroleum generation. In conclusion, these studies suggest the strong influence of temperature on petroleum systems.

\section{REFERENCES CITED}

Ammosov, I.I., 1981, Petrographic features of solid organic materials as indicators of paleotemperatures and oil potential: International Geology Review, v. 23, p. 406-416.

Barker, C.E., 1983, The influence of time on metamorphism of sedimentary organic matter in selected geothermal systems, western North America: Geology, v. 11, p. 384-388.

1988, Temperature and time in the thermal maturation of sedimentary organic matter, in Naeser, N.D., and McCulloch, Thane, eds., Thermal history of basins: Methods and case histories: Berlin, Springer-Verlag, p. 73-97.

in press, Fluid inclusion, vitrinite reflectance, and Rock-Eval pyrolysis evidence for temporal changes in geothermal gradient within the Mesaverde Group, Multiwell Experiment area, Piceance basin, Colorado, in Law, B.E., ed., U.S. Geological Survey Bulletin.

Barker, C.E., and Halley, R.B., 1986, Fluid inclusion, stable isotope, and vitrinite reflectance evidence for the thermal history of the Bone Spring Limestone, southern Guadalupe Mountains, Texas, in Gautier, D.L., ed., Roles of organic matter in sediment diagenesis: Society of Economic Paleontologists and Mineralogists Special Publication 38, p. 190-203.

Barker, C.E., and Pawlewicz, M.J., 1986, The correlation of vitrinite reflectance with maximum temperature in humic organic matter, in Buntebarth, G., and Stegena, L., eds., Paleogeothermics: New York, Springer-Verlag, p. 79-93.

1987, The effects of igneous intrusions and higher heat flow on the thermal maturity of Leonardian and younger rocks, western Delaware basin, Texas, in Cromwell, D.W., ed., Glass Mountains guidebook: Midland, Texas, Permian Basin Section, Society of Economic
Mineralogists and Paleontologists, p. 69-83.

Dembicki, H., Jr., 1984, An interlaboratory comparison of source rock data: Geochimica et Cosmochimica Acta, v. 48, p. 2641-2649.

Gretener, P.E., 1981, Geothermics: Using temperature in hydrocarbon exploration: American Association of Petroleum Geologists, Education Course Notes 17, $156 \mathrm{p}$.

Hunt, J.M., 1979, Petroleum geochemistry and geology: San Francisco, Freeman, 617 p.

Kinney, D.M., ed., 1976, Geothermal gradient map of North America: American Association of Petroleum Geologists and U.S. Geological Survey, scale 1:5,000,000, 2 sheets.

Kisch, H.J., 1987, Correlation between indicators of very-low-grade metamorphism, in Frey, M., ed., Low temperature metamorphism: Glasgow, Blackie and Son, p. 228-300.

Law, B.E., Nuccio, V.F., and Barker, C.E., in press, Kinky vitrinite reflectance profiles: Evidence of paleopore pressure in low-permeability gasbearing sequences in Rocky Mountain foreland basins: American Association of Petroleum Geologists Bulletin.

Naeser, N.D., 1984, Fission-track ages from the Wagon Wheel no. 1 well, northern Green River basin, Wyoming; Evidence for recent cooling, in Law, B.E., ed., Geological characteristics of lowpermeability Upper Cretaceous and lower Tertiary rocks in the Pinedale area, Sublette County, Wyoming: U.S. Geological Survey Open-File Report 84-753, p. 66-77.

Naeser, N.D., and McCulloch, Thane, 1988, Introduction and overview, in Naeser, N.D., and McCulloch, Thane, eds., Thermal history of basins: Methods and case histories: Berlin, Springer-Verlag, p. 1-11.

Pollastro, R.M., and Barker, C.E., 1986, Application of clay-mineral, vitrinite reflectance, and fluid inclusion studies to the thermal and burial history of the Pinedale anticline, Green River basin, Wyoming, in Gautier, D.L., ed., 1986, Roles of organic matter in sediment diagenesis: Society of Economic Paleontologists and Mineralogists Special Publication 38, p. 73-83.

Price, L.C., 1983, Geologic time as a parameter in organic metamorphism and vitrinite reflectance as an absolute paleogeothermometer: Journal of Petroleum Geology, v. 6, p. 5-38.

Robert, P., 1980, The optical evolution of kerogen and geothermal histories applied to oil and gas exploration, in Durand, B., ed., Kerogen: Paris, Editions Technip, p. 385-414.

Schmoker, J.W., 1984, Empirical relation between carbonate porosity and thermal maturity: An approach to regional porosity prediction: 
American Association of Petroleum Geologists Bulletin, v. 68, p. 1697-1703.

Suggate, R.P., 1982, Low rank sequences and scales of organic metamorphism: Journal of Petroleum Geology, v. 4, p. 377-392.

Till, R., 1974, Statistical methods for the Earth
scientist-An introduction: London, Macmillan, $154 \mathrm{p}$.

Wood, J.R., and Hewett, T.A., 1985, Reservoir diagenesis and convective fluid flow, in Mcdonald, D.A., and Surdam, R.C., eds., Clastic diagenesis: Tulsa, American Association of Petroleum Geologists, p. 99-110. 


\title{
Thermal Maturity
}

\author{
By J. David King and Mark J. Pawlewicz
}

\section{INTRODUCTION}

Substantial evidence indicates that much of the observed petroleum and natural gas in the world derives from thermal alteration of organic compounds found in sedimentary rocks. These organic compounds are diagenetic products of material originating in the biosphere at the time of deposition of the sedimentary rocks (Ourisson and others, 1984). The key word here is thermal. This implies that organic-rich rocks that have not been heated to some degree will not have produced commercially significant quantities of oil or gas. Possible heat sources include heat flow from radioactive decay within the Earth's crust, tectonically controlled events that change heat flow locally, volcanism and intrusions, and heat flow by fluid transport.

The ultimate goal of thermal maturity assessment is to determine as accurately as possible the temperature history of sedimentary rocks. Once the temperature history is defined, it can be used to predict the time at which expulsion of oil and gas occurred and thus constrain migration pathways and entrapment mechanisms (Waples, 1985). In practice, a study of the temperature history of any petroleum system consists of estimation of rock temperature through geologic time, refinement of the initial estimate based on various kinds of measurements of rock properties, and construction of a "model" of source rock maturity. It is important to note that the actual values obtained from measurement of rock properties are not in themselves the thermal maturity of the rock, but merely indicative of the temperature history of the rock.

\section{INITIAL ESTIMATE}

Basic to any thermal maturity study is a complete geologic history of the rocks in question. In the case of a typical sedimentary basin, this includes burial history and tectonics as well as temperature and heat-flow measurements (for example, see Chapman and others, 1984; Mackenzie and McKenzie, 1983; Pitman and others, 1987). The only way to get an accurate picture of an entire basin is to construct separate burial-thermal history diagrams for many locations within the basin (Beaumont and others, 1985). Thus, as a minimum, the initial temperature history estimate must be based upon rock thicknesses, ages, and postulated heat flows (or geothermal gradients)—usually derived from stratigraphic and bottom-hole temperature data.

\section{MEASUREMENT OF ROCK PROPERTIES}

Physical and chemical analyses of rock properties influenced by heating can be divided into two basic groups.

Properties of inorganic material include silica phase changes (Isaacs, 1982), clay mineral diagenesis, fission-track annealing (Gleadow and others, 1983; Naeser and Naeser, 1985), and isotope measurement (Harrison and Be, 1983).

Properties of organic material include vitrinite reflectance $\left(R_{m}\right)$, spore/pollen translucency and thermal alteration index (TAI), conodont alteration index (CAI; Epstein and others, 1977), gas chromatographic odd-even predominance (OEP; Scalan and Smith, 1970), temperature of maximum pyrolysis products $\left(\mathrm{T}_{\max }\right)$, molecular reactions (Mackenzie, 1984), and fluid inclusions (Burruss, 1985).

Since these analyses measure properties of the rock or organic material that respond differently to temperature and time, measurement of more than one of the parameters can significantly improve the initial timetemperature estimate. A complete assessment of basinwide thermal maturity requires that different kinds of analyses be performed on many samples from locations throughout the basin.

\section{REFINEMENT OF THE INITIAL ESTIMATE}

A link must be established between the estimated thermal history and each of the rock properties that have been determined quantitatively. This is accomplished by thermal maturity modeling. If discrepancies arise from this procedure, it can be assumed that either the estimated thermal history is in error or the thermal maturity model invoked is unacceptable.

One widely used thermal maturity model is time-temperature index (TTI). TTI values can be "correlated" with properties such as $\mathrm{R}_{\mathrm{m}}, \mathrm{TAI}, \mathrm{T}_{\max }$ (Waples, 1985) and extent of completion of certain molecular reactions (King and Claypool, 1983). The validity of this model may be in question, however (Schmoker, 1986). 
Recently, individual kinetic maturity models have come into favor, mainly because of their specificity toward measured quantities; that is, different mathematical procedures are used for each of the different measured properties. Kinetic models have been applied with considerable success to molecular reaction parameters (Alexander and others, 1986; Beaumont and others, 1985), although they are not restricted solely to these maturity measures (Antia, 1986). Armed with the predictions of the thermal maturity model and geochemical analyses, one should be able to find an acceptable thermal history by appropriate manipulation of the initial time-temperature estimate (Lerche, 1988).

\section{THERMAL RELEASE OF ORGANICS AS OIL AND GAS}

An assessment of thermal maturity alone does not provide sufficient information to accurately determine temporal and spatial occurrence of petroleum and natural gas. The only link between the thermal maturity study and release of oil and gas is a well-defined paleothermal history and its use to model kerogen breakdown, compaction, fluid flow, fluid pressure, pore geometry, and other considerations that are crucial to understanding the release of oil and gas from their point of origin.

Modeling of kerogen breakdown to oil or gas can be as simple as defining a TTI oil or gas "window" (Waples, 1985) or as complex as kinetic modeling (Bumham and others, 1987; Ungerer and Pelet, 1987). The technique used and the validity of the assessment depend upon the availability of good geological and geochemical data.

\section{REFERENCES CITED}

Alexander, R., Strachan, M.G., Kagi, R.I., and van Bronswijk, W., 1986, Heating rate effects on aromatic maturity indicators: Organic Geochemistry, v. 10, p. 997-1003.

Antia, D.D.J., 1986, Kinetic method for modeling vitrinite reflectance: Geology, v. 14, p. 606-608.

Beaumont, C., Boutilier, R., Mackenzie, A., and Rulkötter, J., 1985, Isomerization and aromatization of hydrocarbons and the paleothermometry and burial history of Alberta Foreland Basin: American Association of Petroleum Geologists Bulletin, v. 69, no. 4, p. 546-566.

Burnham, A.K., Braun, R.L., Gregg, H., and Samoun, A., 1987, Comparison of methods for measuring kerogen pyrolysis rates and fitting kinetic parameters: 193d Meeting of the American Chemical Society, April 6, 1987, Denver, Colo., p. 1-27.

Burruss, R.C., 1985, Paleotemperatures from fluid inclusions-Advances in theory and technique [abs.]: American Association of Petroleum Geologists Bulletin, v. 69, no. 2, p. 241.

Chapman, D., Keho, T., Bauer, M., and Picard, D., 1984, Heat flow in the Uinta Basin determined from bottom hole temperature (BHT) data: Geophysics, v. 49, no. 4, p. 453-466.

Epstein, A., Epstein, J., and Harris, L., 1977, Conodont color alteration-An index to organic metamorphism: U.S. Geological Survey Professional Paper 995, 27 p.

Gleadow, A.J.W., Duddy, I., and Lovering, J.F., 1983, Fission track analysis: A new tool for the evaluation of thermal histories and hydrocarbon potential: APEA Journal, p. 93-102.

Harrison, M.T., and $\mathrm{Be}, \mathrm{K} ., 1983,{ }^{40} \mathrm{Ar} /{ }^{39} \mathrm{Ar}$ age spectrum analysis of detrital microclines from the southern San Joaquin basin, California: An approach to determine the thermal evolution of sedimentary basins: Earth and Planetary Science Letters, v. 64, p. 244-256.

Isaacs, C.M., 1982, Influence of rock composition on kinetics of silica phase changes in the Monterey Formation, Santa Barbara area, California: Geology, v. 10, p. 304-308.

King, J.D., and Claypool, G.E., 1983, Biological marker compounds and implications for generation and migration of petroleum in rocks of the Point Conception deep-stratigraphic test well, OCSCAL 78-164 no. 1, offshore California, in Isaacs, C., and Garrison, R., eds., Petroleum generation and occurrence in the Miocene Monterey Formation, California: Bakersfield, Pacific Section, Society of Economic Paleontologists and Mineralogists, p. 191-200.

Lerche, I., in press, Inversion of multiple thermal indicators: Quantitative methods of determining paleoheat flux and geological parameters I. The theoretical development: Mathematical Geology.

Mackenzie, A.S., 1984, Applications of biological markers, in Brooks, J., and Welte, D., eds., Advances in petroleum geochemistry, v. 1: p. $115-214$.

Mackenzie, A.S., and McKenzie, D.H., 1983, Isomerization and aromatization of hydrocarbons in sedimentary basins formed by extension: Geological Magazine, v. 120, no. 5, p. 417-528.

Naeser, N.D., and Naeser, C.W., 1985, Fission-track dating and its application to the thermal history of sedimentary basins [abs.]: American Association of Petroleum Geologists Bulletin, v. 69 , no. 2 , p. 191. 
Ourisson, G., Albrecht, P., and Rohmer, M., 1984, The microbial origin of fossil fuels: Scientific American, v. 251, no. 2, p. 44-51.

Pitman, J.K., Franczyk, K.J., and Anders, D.E., 1987, Marine and nonmarine gas-bearing rocks in upper Cretaceous Blackhawk and Neslen Formations, Eastern Uinta Basin, Utah: Sedimentology, diagenesis and source rock potential: American Association of Petroleum Geologists Bulletin, v. 71, no. 1, p. 76-94.

Scalan, R.S., and Smith, J.E., 1970, An improved measure of the odd-even predominance in the normal alkanes of sediment extracts and petroleum: Geochimica et Cosmochimica Acta, v. 34, p. $611-620$.
Schmoker, J.W., 1986, Oil generation in the Anadarko Basin, Oklahoma and Texas: Modeling using Lopatin's method: Oklahoma Geological Survey Special Publication 86-3, 40 p.

Ungerer, P., and Pelet, R., 1987, Extrapolation of the kinetics of oil and gas formation from laboratory experiments to sedimentary basins: Nature, v. 327, p. $52-54$.

Waples, D.W., 1985, Geochemistry in petroleum exploration: Boston, International Human Resources Development Corp., Geological science series, 232 p. 


\title{
Primary and Secondary Hydrocarbon Migration
}

\author{
By Charles W. Spencer
}

Hydrocarbon migration is a critical element of any petroleum system. Migration takes place through a simple to sometimes complex "plumbing" system that starts with source-bed expulsion and continues through to the ultimate site of entrapment. Primary migration involves the movement of hydrocarbons from the site of generation in a source bed to expulsion into a reservoir rock or carrier bed. Secondary migration is the movement of hydrocarbons within the carrier beds of the petroleum system. Under ideal conditions, secondary migration results in an economically recoverable accumulation of hydrocarbons in a trap. The term tertiary migration is sometimes applied to the subsequent remigration of a previous accumulation of oil or gas.

In spite of many years of petroleum research and exploration, there is still a wide diversity of opinion on exactly how primary migration occurs (Roberts and Cordell, 1980; Durand, 1983; Tissot, 1984). Methods of secondary migration are less controversial. In the 1960's and 1970's primary migration by water-driven hydrocarbon expulsion became a popular explanation. The source of water was generally believed to be water released as a result of the alteration of smectite to illite, or water released as sediments compact and consequently expel water incorporated in argillaceous sediments at the time of deposition (Powers, 1967; Burst, 1969; Magara, 1976). Primary migration related to water expulsion may involve hydrocarbons dissolved in water (Price, 1976), free hydrocarbons, or oily compounds as emulsions or dissolved by natural soaps (micellar migration) (Baker, 1962; Cordell, 1973). All require some method to recombine the dispersed hydrocarbons into a discrete oil or gas phase. These types of primary migration are not a likely explanation for many giant oil and gas accumulations. Also, several recent authors have pointed out that most rocks are fairly well compacted when buried to sufficient depths (and heat) to generate significant volumes of oil and gas (Cordell, 1972; Jones, 1980; Durand, 1983). Furthermore, whereas rapidly filled young basins have slightly undercompacted water-bearing rock sequences, basins characterized by slow deposition contain rocks that are usually well compacted and lithified when peak hydrocarbon generation takes place. Finally, many major source beds worldwide do not contain smectitic clay, hence water is unavailable from this source.

Diffusion of light hydrocarbons through source beds and seals has been suggested as a primary migration mechanism (Pandey and others, 1974; Leythaeuser and others, 1982). Rates of diffusion are influenced by molecule size, concentration, temperature, and other factors. Diffusion is a mechanism by which gases can migrate out of source beds and traps but it is generally a dispersive process and not a means to effectively concentrate hydrocarbons.

Migration of oil and gas as continuous-phase hydrocarbons is the most plausible mechanism for primary expulsion from source beds (Meissner, 1976, 1978, 1985; Jones, 1980; Durand, 1983). Naturally, sufficient concentrations of liquid or gaseous hydrocarbons have to be present in the source bed to saturate the pore fluids and pore space, after which differential pressures caused by hydrocarbon generation, compaction of kerogen, and other factors act to expel the oil and gas into available reservoir rocks. The mobility of heavier organic molecules is likely facilitated by the generation of methane and carbon dioxide from thermal maturation of kerogen. The volume increase from gas generation plus the compaction of kerogen can cause elevated pressures in the source rock even to the point of microfracturing (Cordell, 1972; Hedberg, 1974, 1980; Meissner, 1978).

As noted earlier, secondary migration is moderately well understood. Many studies tying oils to source beds, and geologic and engineering studies of the behavior of oil- and gas-phase migration, strongly support the concept of continuous-phase oil and gas migration in reservoir (carrier) beds. This mode of migration explains most major oil and gas accumulations (Ascheubrenner and Achauer, 1960; Schowalter, 1979; Jones, 1980; McAuliffe, 1980; Durand, 1983). However, in special cases, secondary migration may take place by hydrocarbons in solution or as micelles.

The oil globules or gas bubbles coalesce after primary migration out of the source bed. When they form continuous phase stringers or columns of oil or gas, the hydrocarbons are buoyant in water-filled reservoir pore spaces. Under hydrostatic conditions, the hydrocarbon continuous phase must exceed the capillary (or entry) pressure of the largest pore throats of the carrier bed in order to migrate updip. Migration is generally believed to occur in thin continuous hydrocarbon layers or stringers in the uppermost part of the carrier beds. Migration can be assisted by a pressure differential in hydrocarbon-saturated reservoirs, or buoyancy migration can be assisted by hydrodynamic 
updip movement of reservoir water. Oil and gas will begin to accumulate in the top of structural closures or against the updip edges of stratigraphic traps. When the pressure caused by the buoyant, continuous column of hydrocarbons exceeds the entry pressure of the largest pore throats in the seal or updip barrier, the hydrocarbons will penetrate the barrier and a significant volume of the hydrocarbons may leak updip to the next obstruction along the migration route (Berg, 1975; Schowalter, 1979; Downey, 1984). However, updip hydrodynamic flow will cause stratigraphic traps to become less effective as barriers whereas downdip water flow will enhance the trapping ability of capillary traps (Berg, 1975). Abnormally high regional pore pressures may force hydrocarbons into or through seals or along nonsealing faults and fractures. Under certain conditions, strong downdip flow of water may physically displace oil downdip (Hubbert, 1953), but such conditions are not common.

\section{REFERENCES CITED}

Ascheubrenner, B.C., and Achauer, C.W., 1960, Minimum conditions for migration of oil in water-wet carbonate rocks: American Association of Petroleum Geologists Bulletin, v. 44 , no. 2, p. 235-243.

Baker, E.G., 1962, Distribution of hydrocarbons in petroleum: American Association of Petroleum Geologists Bulletin, v. 46, no. 1, p. 76-84.

Berg, R.R., 1975, Capillary pressures in stratigraphic traps: American Association of Petroleum Geologists Bulletin, v. 59, no. 6, p. 939-956.

Burst, J.F., 1969, Diagenesis of Gulf Coast clayey sediments and its possible relation to petroleum migration: American Association of Petroleum Geologists Bulletin, v. 53, no. 1, p. 73-93.

Cordell, R.J., 1972, Depths of oil migration and primary migration-A review and critique: American Association of Petroleum Geologists Bulletin, v. 56, no. 10, p. 2029-2067.

1973, Colloidal soap as proposed primary migration medium for hydrocarbons: American Association of Petroleum Geologists Bulletin, v. 57, no. 9, p. 1618-1643.

Downey, M.W., 1984, Evaluating seals for hydrocarbon accumulations: American Association of Petroleum Geologists Bulletin, v. 68, no. 11, p. 1752-1763.

Durand, B., 1983, Present trends in organic geochemistry in research on migration of hydrocarbons, in Bjoroy, M., ed., Advances in organic geochemistry 1981: New York, John Wiley \& Sons, p. 117-128.

Hedberg, H.D., 1974, Relation of methane generation to undercompacted shales, shale diapirs, and mud volcanoes: American Association of Petroleum Geologists Bulletin, v. 58, no. 4, p. 661-673.

1980, Methane generation and petroleum migration, in Roberts, W.H., III, and Cordell, R.J., eds., Problems of petroleum migration: American Association of Petroleum Geologists Studies in Geology 10, p. 179-206.

Hubbert, M.K., 1953, Entrapment of petroleum under hydrodynamic conditions: American Association of Petroleum Geologists Bulletin, v. 37, no. 9, p. 1954-2026.

Jones, R.W., 1980, Some mass balance and geological constraints on migration mechanisms, in Roberts, W.H., III, and Cordell, R.J., eds., Problems of petroleum migration: American Association of Petroleum Geologists Studies in Geology 10, p. 47-68.

Leythaeuser, Detlev, Schaefer, R.G., and Yukler, Arif, 1982, Role of diffusion in primary migration of hydrocarbons: American Association of Petroleum Geologists Bulletin, v. 66, no. 4, p. $408-429$.

Magara, Kinji, 1976, Water expulsion from clastic sediments during compaction-Directions and volumes: American Association of Petroleum Geologists Bulletin, v. 60, no. 4, p. 543-553.

McAuliffe, C.D., 1980, Oil and gas migration-Chemical and physical constraints, in Roberts, W.H., III, and Cordell, R.J., eds., Problems of petroleum migration: American Association of Petroleum Geologists Studies in Geology 10, p. 89-107.

Meissner, F.F., 1976, Abnormal electric resistivity and fluid pressure in Bakken Formation, Williston basin and its relation to petroleum generation, migration and accumulation [abs.]: American Association of Petroleum Geologists Bulletin, v. 60 , no. 8, p. 1403-1404.

1978, Petroleum geology of the Bakken Formation, Williston basin, North Dakota and Montana, in 24th Annual Conference, Williston Basin Symposium: Billings, Montana Geological Society, p. 207-227.

1985, Regional hydrocarbon generation, migration, and accumulation pattern of Cretaceous strata, Powder River basin [abs.]: American Association of Petroleum Geologists Bulletin, v. 69 , p. 856.

Pandey, G.N., Tek, M.R., and Katz, D.L., 1974, Diffusion of fluids through porous media with implications in petroleum geology: American Association of Petroleum Geologists Bulletin, v. 58 , no. 2, p. 291-303.

Powers, M.C., 1967, Fluid release mechanisms in compacting marine mudrocks and their 
importance in oil exploration: American Association of Petroleum Geologists Bulletin, v. 51 , no. 7, p. 1240-1254.

Price, L.C., 1976, Aqueous solubility of petroleum as applied to its origin and primary migration: American Association of Petroleum Geologists Bulletin, v. 60, no. 2, p. 213-244.

Roberts, W.H., III, and Cordell, R.J., 1980, eds., Problems of petroleum migration: American Association of Petroleum Geologists Studies in Geology 10, 273 p.
Schowalter, T.T., 1979, Mechanics of secondary hydrocarbon migration and entrapment: American Association of Petroleum Geologists Bulletin, v. 63, p. 723-760.

Tissot, B.P., 1984, Recent advances in petroleum geochemistry applied to hydrocarbon exploration: American Association of Petroleum Geologists Bulletin, v. 68, no. 5, p. 545-563. 


\title{
Structure
}

\author{
By William J. Perry, Jr.
}

In its most limited sense, structure is the threedimensional shape of a body of rock, whether we are dealing with a single bed, a sedimentary basin, a mountain belt, or the Earth. Structure also concerns the internal morphology of rocks, whether we are discussing the structure of pore throats, other microscopic fabrics, or the internal morphology of mountain belts. Both shape and internal morphology are necessary ingredients of petroleum systems.

So-called structure maps (as used in the petroleum industry) are simply contour maps of the present elevations of a reference horizon, commonly bedding, contoured in feet or meters above or below sea level. These maps are used to define structural closures such as four-way closures, in which beds dip away on all sides, or fault-bounded closures, in which beds dip away from a bounding fault(s). Hydrocarbons will migrate updip along permeable layers into such closures, if closures are present, unless trapped by a permeability barrier. Structural closures may then become traps for hydrocarbons if vertical migration is prevented by the presence of a seal, generally an impermeable layer or sequence of layers above the permeable zone. The paleostructure (preexisting structure) of a region is becoming recognized to be of great importance to petroleum systems: the closures that were present during peak hydrocarbon generation and migration are those most likely to contain significant quantities of hydrocarbons.

Structures may be broadly subdivided into (1) folds, which are continuous, caused by buckling or flowage or a combination of both, and (2) faults, which disrupt the continuity of rock layers and along which movement has occurred. Faults belong to a larger family of structures formed by brittle deformation known as fractures, planar features across which a loss of cohesion has occurred. In the parlance of rock mechanics, faults are shear fractures. The second major family of fractures are commonly called joints or rock joints. These are extension fractures, characterized by lack of displacement along their surfaces; they have extended or dilated the rock body in which they occur. These are of particular importance to petroleum systems in that they create secondary porosity. Of equal importance, they form part of what is called a "dual permeability" system: permeability pathways along an interconnected fracture and interstitial pore-space network. The direction of extension fracture alignment is normally the direction in which fluids will move most readily, unless such fractures are sealed by calcite or other minerals. Such mineral-filled fractures are commonly termed veins. Fracture development and propagation has been the subject of intensive laboratory and theoretical analysis, summarized with respect to rocks by Ramsay (1967) and Suppe (1985).

Structural styles include those of extensional, compressional, and wrench-fault tectonics, each with its family of characteristic structures, structural processes, and structural relationships, and each with a different history of petroleum generation, migration, and trapping based in part on these different processes and relationships (Harding and Lowell, 1979).

Extensional tectonics is a rapidly growing field of investigation. Principal examples of extensional terranes, those in which the Earth's crust has undergone extension, are the Basin and Range Province of the western United States, the Aegean Sea, and the North Sea petroleum province (Armstrong, 1972; Wernicke and Burchfiel, 1982; Mayer, 1986; Coward and others, 1987). Passive continental margins, such as the Gulf Coast offshore petroleum province, the Niger delta, and the Baltimore Canyon trough offshore from the U.S. east coast, form another class of extensional terranes. Such regions are characterized by crustal thinning and relatively high heat flow during extension. Rifts, such as the Midcontinent rift, Red Sea rift, and southern Oklahoma aulacogen, are also examples of extensional terranes (Hoffman and others, 1974; Keller and others, 1983; Burke, 1980; Feinstein, 1981; Suppe, 1985). Hydrocarbon traps are commonly bounded by extension (normal) faults in such terranes; traps in rift settings were summarized by Harding (1984).

Compressional tectonics, the study of fold and thrust belts, was put on a firm theoretical basis by Chapple (1978) and is a rapidly expanding field of research (McClay and Price, 1981; Perry and others, 1984). Compressional terranes, generally known as orogenic belts, are characterized by crustal thickening and variable heat flow. Principal examples are the Alpine-Himalayan, Appalachian, and Cordilleran orogenic belts. Compressional tectonism is the tectonic style characteristic also of accretionary wedges developed along active convergent plate margins (Boyer, 1985; Moore and Byrne, 1987). The association of hydrocarbons with foreland margins of fold and thrust belts has spurred research by the petroleum industry, 
particularly during the 1970's and early 1980's (Perry and others, 1984). Hydrocarbon trap styles in compressional terranes are summarized by Boyer (1985).

Wrench-fault tectonics, the study of structures associated with major strike-slip faults, is receiving increasing attention (for example Biddle and ChristieBlick, 1985). The San Andreas fault system of central and southern California (Sylvester, 1984) is a primary example of wrench-fault tectonism. Hybrid structural styles, such as transpression and transtension, briefly discussed below, are not necessarily the result of largescale wrench faulting, and are considered separately. Hydrocarbon trap styles associated with wrench-fault systems were summarized by Harding (1974) and Harding and Lowell (1979).

Hybrid styles, such as those of transtensional and transpressional tectonism, are now being recognized and studied (Harland, 1971; Schmidt and Garihan, 1983; Sanderson and Marchini, 1984; McCoss, 1986). These hybrid styles are found where rocks or basins or orogenic belts have been compressed or extended oblique to earlier formed planes or directions of weakness, where such planes or directions have controlled subsequent patterns. Primary examples are the Rocky Mountain foreland province, Anadarko basin, Spitzbergen, and the Gulf of California (Harland, 1971; Sales, 1968; Schmidt and Garihan, 1983; Lorenz, 1984; Harding, 1985; Perry, 1987 and in press).

Each style of tectonism represents a different structural environment of deformation in terms of basin development, heat flow, and plate-tectonic setting. Therefore, each will require a different treatment in terms of petroleum systems; early identification of structurally complex petroleum systems in terms of tectonic style is necessary for understanding and development of each such system.

\section{REFERENCES CITED}

Armstrong, R.L., 1972, Low-angle (denudation) faults, hinterland of the Sevier orogenic belt, eastern Nevada and western Utah: Geological Society of America Bulletin, v. 83, p. 1729-1754.

Biddle, K.T., and Christie-Blick, N., eds., 1985, Strikeslip deformation, basin formation and sedimentation: Society of Economic Paleontologists and Mineralogists Special Publication 37, $386 \mathrm{p}$.

Boyer, S.E., 1985, Hydrocarbon trap styles in fold-andthrust belts and related terranes: Proceedings 1985 Offshore Technology Conference, contrib. OTC 4873, p. 297-305.

Burke, K., 1980, Intracontinental rifts and aulacogens, in Continental tectonics: Washington, D.C., National Academy of Science, p. 42-49.
Chapple, W.M., 1978, Mechanics of thin-skinned fold and thrust belt: Geological Society of America Bulletin, v. 89, p. 1189-1198.

Coward, M.P., Dewey, J.F., and Hancock, P.L., eds., 1987, Continental extensional tectonics: Geological Society of London Special Publication 28, $637 \mathrm{p}$.

Feinstein, S., 1981, Subsidence and thermal history of the southern Oklahoma aulacogen: Implications for petroleum exploration: American Association of Petroleum Geologists Bulletin, v. 65, p. 2521-2533.

Harding, T.P., 1974, Petroleum traps associated with wrench faults: American Association of Petroleum Geologists Bulletin, v. 58, p. 1290-1304.

1984, Graben hydrocarbon occurrences and structural style: American Association of Petroleum Geologists Bulletin, v. 68, p. 333-362.

1985, Seismic characteristics and identification of negative flower structures, positive flower structures, and positive structural inversion: American Association of Petroleum Geologists Bulletin, v. 69 , p. $582-600$.

Harding, T.P., and Lowell, J.D., 1979, Structural styles, their plate-tectonic habitats and hydrocarbon traps in petroleum provinces: American Association of Petroleum Geologists Bulletin, v. 63, p. 1016-1058.

Harland, W.B., 1971, Tectonic transpression in Caledonian Spitzbergen: Geological Magazine, v. 108, p. $27-42$.

Hoffman, P., Dewey, J.F., and Burke, K., 1974, Aulacogens and their genetic relations to geosynclines, with a Proterozoic example from Great Slave Lake, Canada, in Dott, R.H., Jr., and Shaver, R.H., eds. Modern and ancient geosynclinal sedimentation: Society of Economic Paleontologists and Mineralogists Special Publication 19, p. 38-55.

Keller, G.R., Lidiak, E.G., Hinze, W.J., and Braile, L.W., 1983, The role of rifting in the tectonic development of the midcontinent, USA, in Morgan, P., and Baker, B.H., eds., Processes of continental rifting: Tectonophysics, v. 94, p. $391-412$.

Lorenz, J.C., 1984, The role of the Lewis and Clark fault system during the Laramide orogeny, in Northwest Montana and adjacent Canada: Montana Geological Society 1984 Field Conference and Symposium Guidebook, p. 221-230.

McClay, K.R., and Price, N.J., eds., 1981, Thrust and nappe tectonics: Geological Society of London Special Publication 9, $539 \mathrm{p}$. 
McCoss, A.M., 1986, Simple constructions for deformation in transpression/transtension zones: Journal of Structural Geology, v. 8, 715-718.

Mayer, L., ed., 1986, Extensional tectonics of the southwestern United States: A perspective on processes and kinematics: Geological Society of America Special Paper 208, 130 p.

Moore, J.C., and Byrne, T., 1987, Thickening of fault zones: A mechanism of melange formation in accreting sediments: Geology, v. 15, p. 1040-1043.

Perry, W.J., Jr., 1987, Structural development of the southeastern margin of the Anadarko basin [abs]: Geological Society of America Abstracts with Programs, v. 19, p. 176.

Perry, W.J., Jr., in press, Tectonic evolution of the Anadarko basin region, Oklahoma, in Stoesser, J., ed., Evolution of sedimentary basinsAnadarko basín: U.S. Geological Survey Bulletin 1866A.

Perry, W.J., Jr., Roeder, D.H., and Lageson, D.R., compilers, 1984, North American thrust-faulted terranes: American Association of Petroleum Geologists Reprint Series 27, 466 p.
Ramsay, J.G., 1967, Folding and fracturing of rocks: New York, McGraw-Hill, 568 p.

Sales, J.K., 1968, Crustal mechanics of Cordilleran foreland deformation: A regional and scale model approach: American Association of Petroleum Geologists Bulletin, v. 52, p. 2016-2044.

Sanderson, D.J., and Marchini, W.R.D., 1984, Transpression: Journal of Structural Geology, v. 6 , p. 449-458.

Schmidt, C.J., and Garihan, J.M., 1983, Laramide tectonic development of the Rocky Mountain foreland of southwestern Montana, in Lowell, J.D., ed., Rocky Mountain foreland basins and uplifts: Denver, Rocky Mountain Association of Geologists, p. 271-294.

Suppe, J., 1985, Principles of structural geology: Englewood Cliffs, New Jersey, Prentice-Hall, $537 \mathrm{p}$.

Sylvester, A.G., compiler, 1984, Wrench fault tectonics: American Association of Petroleum Geologists Reprint Series 28, 374 p.

Wernicke, B.P., and Burchfiel, B.C., 1982, Modes of extensional tectonics: Journal of Structural Geology, v. 4, p. 105-115. 


\title{
Types of Seals as Related to \\ Migration and Entrapment of Hydrocarbons
}

\author{
By Gregory F. Ulmishek
}

The importance of seals as a decisive factor in controlling migration of hydrocarbons and their entrapment and preservation through geologic time is often underestimated by petroleum geologists, especially in a regional geologic analysis.

Theoretically, the properties of rocks that control their seal capacity are well understood on the basis of laboratory experiments (Prozorovich, 1972; Schowalter, 1979; Downey, 1984). The capacity of a seal is defined by the capillary entry (or hydrocarbonwater displacement) pressure, which depends on the fluid's interfacial tension, wettability of rocks, and the radius of pore throats. A bed may be considered a seal if the constituting rock is characterized by a capillary pressure that exceeds the buoyancy force of the underlying continuous hydrocarbon phase (pool or filaments in oil-stained rock). Theoretically, the seal capacity of a bed does not depend on its thickness and ductility, but mainly on the size of the connected pore throats. A bed remains impermeable to oil and gas as long as the buoyancy force does not exceed the capillary entry pressure in largest pores. When this happens, a breakthrough occurs, and once a continuous oil (or gas) phase is established through the seal, a large part of the hydrocarbons escapes upward until the capillary pressure causes the seal to reestablish itself (Schowalter, 1979). Hydrodynamic forces can significantly enhance or reduce the seal capacity of a bed depending on the direction of the water movement. Downward-directed hydrodynamic gradients enhance seals, whereas upward flow will decrease sealing capacity of rocks.

Diffusion of hydrocarbon molecules through a seal is a much less effective mechanism for transport of oil and gas than continuous phase migration. The rate of diffusion for a particular compound depends on its molecular size and the volume of water-filled connected pore space in a seal. Most probably, diffusion does not affect secondary migration and preservation of oil pools, but in some cases may be significant for preservation of gas accumulations through extended periods of geologic time (Leythaeuser and others, 1982).

In a geologic environment, however, other large-scale qualities of a seal that cannot be described from physical analyses of cores are more important. The most significant of these qualities are resistance to brittle fracturing, lateral continuity and areal extent, pore overpressure, thickness, and homogeneity. Migration of hydrocarbons in geologic conditions, especially vertical migration, occurs through fracture systems, because even the smallest fracture represents an extraordinary conduit for migrating fluids (Schowalter, 1979). On the basis of ability of a rock to resist fracturing and to quickly seal fault planes, the seals can be subdivided into brittle and plastic. Other classifications based on the lithologic composition (such as evaporite, shale, or carbonate seals; Nalivkin, 1983) chiefly emphasize the same quality. Plastic seals (evaporites, uncompacted shales) are the best barriers to hydrocarbon migration. Brittle seals are, as a rule, only locally impermeable. Regionally, they can be fairly good seals only if their quality is enhanced by a downward hydrodynamic flow as is known, for example, for the Devonian Kynov Shale in the TimanPechora province of the USSR (Chernikov and Sverchkov, 1974).

According to their lateral continuity and areal extent, seals can be separated into regional and local. Although both groups can control oil and gas pools, the effect of regional seals on the productivity of a region is much more significant. Regional seals control the entire hydrodynamic regime in underlying permeable formations and, hence, strongly affect the migration and accumulation of hydrocarbons and preserve oil and gas pools from destruction. Over large areas, good regional seals prevent hydrocarbons from escaping upward and thus create a natural boundary for a petroleum system (or independent petroliferous system, IPS, according to Ulmishek, 1986). Local seals of small extent are effective only in the presence of a regional seal higher in the section. Significant hydrocarbon reserves in pools controlled only by local seals are uncommon and usually indicate strong predominance of vertical over lateral migration in formation of these pools.

Overpressured shale formations (undercompacted shales) are excellent seals owing to the hydrodynamic gradient directed downward into underlying permeable rocks that usually have lower reservoir pressure. This hydrodynamic gradient effectively prevents hydrocarbons from escaping from rocks beneath the overpressured shale into overlying formations. On this basis, the overpressured shales are sometimes classified as the hydrodynamic class of seals versus other seals that are not characterized by abnormal pressure and whose sealing quality is controlled only by the structure of the pore space (Beka and Vysotskiy, 
1976). Additionally, overpressured shale formations are usually thick and ductile due to a high amount of pore water.

The thickness is evidently an important quality of a seal, especially of a regional seal. Greater thickness terminates minor defects, such as occasional pore channels and fractures, inside the seal, and decreases chances for the appearance of windows of permeability that can be created by local facies changes, erosion, or faulting. In the case of faulting, thick seals are especially important because even small-scale faulting can place the bottom of a relatively thin seal against permeable rocks and thus cut the migration paths or allow traps to leak. The vertical homogeneity of a seal is, to a significant degree, analogous to its thickness. Nonhomogeneous seals that include interbeds of permeable rocks, such as sandstone and siltstone, are essentially less reliable due to the small thickness of individual shale beds. Measurements of the concentration and composition of dispersed bitumen in shale and siltstone over a number of oil pools in the USSR showed that the height of penetration of migrated oil into the seals varied from 30 to $50 \mathrm{~m}$. The content of vertically migrated oil in poor seals (for example, in siltstone interbeds) is only an order of magnitude less than in the underlying productive strata (Larskaya and Polyanskaya, 1987). Thus, for example, a shale $50 \mathrm{~m}$ thick is generally a better seal than a 100-m-thick alternation of shale and siltstone layers in which the thickness of shale totals the same $50 \mathrm{~m}$.

In discussing petroleum systems, it seems appropriate to classify seals by their extent into regional and local, and by their quality into perfect and imperfect. Regional seals are those that are continuous over all or most of the area occupied by a petroleum system, while local seals are developed only in separate zones of the system. Perfect seals are represented by formations that are characterized by plasticity at in-situ conditions or downward-directed hydrodynamic gradient (Ulmishek, 1986). These formations are composed of salt, anhydrite, undercompacted overpressured shale, and plastic shale usually having a high percentage of smectite minerals or plastic kerogen. Possibly permafrost (with associated gas hydrates) also fits the perfect type, although recent data call into question its essentially absolute impermeability (Starobinets and Murogova, 1985; Shershukov and Khudyakov, 1986). Seals of the imperfect type are composed of dense but brittle rocks such as well-compacted shale (often intercalated with siltstone), marl, and dense carbonate. These seals lose their impermeability in zones of faulting and fracturing. Only locally can they control hydrocarbon pools in quiet tectonic regimes. The lifespan of many perfect seals (probably except only anhydrite) is usually restricted to a certain period of geologic time. After burial to significant depths, most perfect seals lose their quality owing to dehydration and compaction, in the case of plastic shale, and salt doming with complete squeezing of salt from the rim synclines, in the case of thick salt beds. Regional perfect seals control the vertical extent of petroleum systems; other types of seals of this classification affect the distribution of oil and gas pools inside the systems.

\section{REFERENCES CITED}

Beka, K., and Vysotskiy, I., 1976, Geology of oil and gas (Geologiya nefti i gaza): Moscow, Nedra, $591 \mathrm{p}$.

Chernikov, K.A., and Sverchkov, G.P., eds., 1974, Criteria of the separate assessment of oil and gas potential: Trudy VNIGNI, v. 334, Leningrad, Nedra, $184 \mathrm{p}$.

Downey, M.W., 1984, Evaluating seals for hydrocarbon accumulation: American Association of Petroleum Geologists Bulletin, v. 68, no. 11, p. 1752-1763.

Larskaya, E.S., and Polyanskaya, V.S., 1987, Evaluation of the quality of seals controlling oil and gas pools: Geologiya Nefti i Gaza, no. 1, p. 22-25.

Leythaeuser, D., Schaefer, R.G., and Yukler, A., 1982, Role of diffusion in primary migration of hydrocarbons: American Association of Petroleum Geologists Bulletin, v. 66, no. 4, p. 408-429.

Nalivkin, V.D., ed., 1983, Genesis and forecast of oil, gas, and bitumen accumulations (Proiskhozhdenie i prognozirovanie skopleniy gaza, nefti i bitumov): Leningrad, Nedra, 272 p.

Prozorovich, G.E., 1972, Seals for oil and gas pools: Moscow, Nedra, 216 p.

Schowalter, T.T., 1979, Mechanics of secondary hydrocarbon migration and entrapment: American Association of Petroleum Geologists Bulletin, v. 63, no. 5, p. 723-760.

Shershukov, V.V., and Khudyakov, V.N., 1986, Migration of coal gases in conditions of permafrost: Sovetskaya Geologiya, no. 5, p. 30-32.

Starobinets, I.S., and Murogova, R.N., 1985, Sealing and conducting role of rocks of the cryogenic zone in relation to migrating hydrocarbons: Geologiya Nefti i Gaza, no. 1, p. 24-27.

Ulmishek, G., 1986, Stratigraphic aspects of petroleum resource assessment, in Rice, D.D., ed., Oil and gas assessment, methods and applications: American Association of Petroleum Geologists Studies in Geology 21, p. 59-68. 


\title{
Sandstone Reservoirs
}

\author{
By Christopher J. Schenk
}

Sandstone bodies are an important part of petroleum systems for two reasons; first, they act as conduits for migrating fluids, and second, sandstones serve as reservoirs. Current research efforts on sandstones generally focus on determining the types and causes of sandstone heterogeneity, which is the spatial variation of physical and chemical properties in a sandstone that generally exerts a deleterious effect on fluid flow. Heterogeneity controls the efficacy of a sandstone to act as a conduit or a reservoir for petroleum. An understanding of fluid-flow pathways in sandstone and their evolution is critical for predictive models of fluid migration and associated diagenetic modifications. From a pragmatic viewpoint, successful secondary and tertiary recovery of petroleum is dependent on a detailed understanding of fluid-flow pathways within sandstone reservoirs.

Heterogeneity is largely a function of sedimentologic characteristics and diagenetic modifications of the sandstone (Weber, 1986). A heirarchy of heterogeneities, outlined by Weber (1986), is modified for the following discussion. The largest scale of heterogeneity is sandstone bodies and their boundaries. The geometry (length, width, thickness) of a sandstone body is controlled by tectonic, sedimentsupply, sea-level, and depositional environment factors (Miall, 1984). Knowledge of regional sandstone-body geometry (ribbon or sheet) is critical for predicting possible routes of petroleum migration. Sandstone bodies can be defined as simple (single genetic unit) or complex (multiple, stacked genetic units), but most appear to be complex deposits (Friend, 1983; Tyler and Ambrose, 1985; Galloway and Cheng, 1985; Tyler and others, 1986; Ebanks and Weber, 1987). Boundaries can be enclosing fine-grained clastics, evaporites, fault contacts, or unconformities. These boundaries are important to characterize because they commonly define the continuity of fluid-flow pathways in a regional context (Galloway, 1984).

The second scale of heterogeneity is what are termed "baffles" to fluid flow within a sandstone. Baffles are manifest mainly by mudstone layers that may range from continuous to discontinuous across the sandstone body (Weber, 1982; Haldorsen and Chang, 1986). These finer grained interbeds are considered by some workers to be the most important form of heterogeneity affecting fluid flow either vertically or horizontally through a sandstone body (Haldorsen and Chang, 1986). Baffles could also be formed by diastems or unconformities within the sandstone body, such as the erosional surfaces between fluvial-channel sandstones in a multistory sandstone body. Baffles of this type could be even more detrimental to fluid flow if they were the focus of subsequent diagenetic alterations that reduce permeability.

Facies represent the third scale of heterogeneity. A facies represents an aspect of a sand body that is sufficiently unique to be described separately from the rest of the sandstone; examples include cosets of ripplelaminated sandstones, cosets of large-scale cross-strata and channel sandstones (Walker, 1984; Reading, 1978). One sandstone may contain numerous facies. Facies form what are now being recognized as "flow units" within sandstone bodies; each flow unit exhibits some common range of porosity and permeability values (Hearn and others, 1986).

Individual sedimentary structures compose the fourth scale of heterogeneity. The geometry of a sedimentary structure dictates the degree of anisotropy of fluid flow at this scale. A structure can be classified as small-scale or large-scale (Allen, 1984); strata within a sedimentary structure can be planar, low-angle, or highangle (cross-strata); the shape of the bounding surfaces can be tabular-planar, wedge-planar, or trough-shaped in cross sections normal to the paleocurrent direction. The orientation and shape of a set of strata or cross-strata can constrain the continuity of fluid flow. Types of stratification exert a profound influence on directional permeabilities. Goggin and others (1986) reported that interdune, eolian ripple, and eolian sandflow cross-strata exhibited significant differences in permeability within an eolian sandstone. These three elements form the basic building blocks for most eolian deposits, and thus can generally be expected to influence permeabilities in eolian sand bodies. In a similar analysis, Hearn and others (1986) concluded that flow units differentiated mainly by sedimentary structures in a shelf sandstone exhibited significant differences in permeabilities.

Sedimentary structures are composed of bundles of similar strata or laminae: each stratum has a unique grain size distribution, and possible vertical or horizontal grain-size grading (Hunter, 1977; Sallenger, 1979; Schenk, 1983, 1987). These characteristics can result in a fifth scale of heterogeneity, as these textural characteristics may influence subsequent diagenetic alterations on a stratum-by-stratum basis (Evans, 1983). 
Diagenetic alterations are the sixth type of heterogeneity. Unlike the several scales of heterogeneity formed at the time of deposition, diagenetic alterations can evolve with time (Pollastro, 1985), they can form at any time in the burial history of a sandstone, and the magnitude of an alteration can change, enhancing or decreasing reservoir quality (through secondary porosity or compaction; Bjorlykke, 1984; Houseknecht, 1987). Phases of sandstone diagenesis are best studied in a burial history context, as a function of both the timetemperature exposure of the sandstone (Schmoker and Gautier, 1988) and the evolving fluid chemistry of the pore-water system (Surdam and others, 1984; Wood and Hewett, 1984).

Fracture systems represent the final type of heterogeneity that affects fluid flow. Unlike most other forms of heterogeneity, fractures serve to enhance permeability and flow continuity (DoRozario and Baird, 1987). However, fractures can have a detrimental effect in that they may cause premature water influx into the reservoir or decrease the effectiveness of secondary or tertiary recovery projects. Timing of fracturing, fracture orientation, and fracture openness are all important to consider (Weber, 1986).

Predicting types of sandstone heterogeneity appears to become more difficult as the scale of heterogeneity decreases (Weber, 1986). In particular, diagenetic and fracture patterns are quite variable in a regional sense, and are especially difficult to predict in areas of limited data.

\section{REFERENCES CITED}

Allen, J.R.L., 1984, Sedimentary structures: Their character and physical basis: Developments in Sedimentology, v. 30, 663 p.

Bjorlykke, K., 1984, Formation of secondary porosity: How important is it?, in McDonald, D.A., and Surdam, R.C., eds., Clastic diagenesis: American Association of Petroleum Geologists Memoir 37, p. 277-288.

DoRozario, R.F., and Baird, B.W., 1987, The detection and significance of fractures in the Palm Valley gas field: Australian Petroleum Exploration Association Journal, v. 27, part 1, p. 264-280.

Ebanks, W.J., and Weber, J.F., 1987, Shallow heavy oil deposit in a Pennsylvanian fluvial sandstone reservoir, Eastburn field, Missouri, in Meyer, R.F., ed., Exploration for heavy crude oil and natural bitumen: American Association of Petroleum Geologists Studies in Geology 25, p. 327-339.

Evans, C.C., 1983, Aspects of depositional and diagenetic history of the Miami/ LimestoneControl of primary sediment fabric over early cementation and porosity development: Coral Gables, Fla., University of Miami, M.S. thesis, $130 \mathrm{p}$.

Friend, P.F., 1983, Toward the field classification of alluvial architecture or sequence, in Collinson, J.D., and Lewin, J., eds., Modern and ancient fluvial systems: International Association of Sedimentologists Special Publication 6, p. 345-354.

Galloway, W.E., 1984, Hydrologic regimes of sandstone diagenesis, in McDonald, D.A., and Surdam, R.C., eds., Clastic diagenesis: American Association of Petroleum Geologists Memoir 37, p. 3-14.

Galloway, W.E., and Cheng, E.S., 1985, Reservoir facies architecture in a microtidal barrier system-Frio Formation, Texas Gulf coast: Texas Bureau of Economic Geology Report of Investigations 144, $36 \mathrm{p}$.

Goggin, D.J., Chandler, M.A., Kocurek, G., and Lake, L.W., 1986, Patterns of permeability in eolian deposits: Society of Petroleum Engineers/U.S. Department of Energy Preprint 14893, p. 181-188.

Haldorsen, H.H., and Chang, D.M., 1986, Notes on stochastic shales; from outcrop to simulation model, in Lake, L.W., and Carroll, H.B., Jr., eds., Reservoir characterization: New York, Academic Press, p. 445-483.

Hearn, C.L., Hobson, J.P., and Fowler, M.L., 1986, Reservoir characterization for simulation, Hartzog Draw field, Wyoming, in Lake, L.W., and Carroll, H.B., Jr., eds., Reservoir characterization: New York, Academic Press, p. 341-371.

Houseknecht, D.W., 1987, Assessing the relative importance of compaction processes and cementation to reduction of porosity in sandstones: American Association of Petroleum Geologists Bulletin, v. 71, p. 633-642.

Hunter, R.E., 1977, Basic types of stratification in small eolian dunes: Sedimentology, v. 24, p. 361-387.

Miall, A.D., 1984, Principles of sedimentary basin analysis: New York, Springer-Verlag, 490 p.

Pollastro, R.M., 1985, Mineralogical and morphological evidence for the formation of illite at the expense of illite/smectite: Clays and Clay Minerals, v. 33, p. 265-274.

Reading, H.G., 1978, Facies, in Reading, H.G., ed., Sedimentary environments and facies: London, Blackwell, p. 4-15.

Sallenger, A.H., 1979, Inverse grading and hydraulic equivalence in grain-flow deposits: Journal of Sedimentary Petrology, v. 49, p. 553-562.

Schenk, C.J., 1983, Textural and structural characteristics 
of some experimentally formed eolian strata, in Brookfield, M.E., and Ahlbrandt, T.S., eds., Eolian sediments and processes: Developments in Sedimentology, v. 38, p. 41-49.

1987, Primary textures in experimentally formed oolite cross-strata: U.S. Geological Survey Bulletin 1670, $11 \mathrm{p}$.

Schmoker, J.W., and Gautier, D.L., 1988, Dependence of sandstone porosity upon thermal maturity-An approach to prediction and interbasinal comparison of porosity: U.S. Geological Survey Circular 1025, $56 \mathrm{p}$.

Surdam, R.C., Boese, S.W., and Crossey, L.J., 1984, The chemistry of secondary porosity, in McDonald, D.A., and Surdam, R.C., eds., Clastic diagenesis: American Association of Petroleum Geologists Memoir 37, p. 127-150.

Tyler, N., and Ambrose, W.A., 1985, Facies architecture and production characteristics of strandplain reservoirs in the Frio Formation, Texas: Texas Bureau of Economic Geology Report of Investigations $146,42 \mathrm{p}$.
Tyler, N., Gholston, J.C., and Ambrose, W.A., 1986, Genetic stratigraphy and oil recovery in an Upper Cretaceous wave-dominated deltaic reservoir, Big Wells (San Miguel) field, South Texas: Texas Bureau of Economic Geology Report of Investigations 153, $38 \mathrm{p}$.

Walker, R.G., 1984, General introduction: Facies, facies sequences and facies models, in Walker, R.G., ed., Facies models, $2 \mathrm{~d}$ ed.: Geoscience Canada Reprint Series 1, p. 1-9.

Weber, K.J., 1982, Influence of common sedimentary structures on fluid flow in reservoir models: Journal of Petroleum Technology, v. 34, p. 665-672.

1986, How heterogeneity affects oil recovery, in Lake, L.W., and Carroll, H.B., Jr., eds., Reservoir characterization: New York, Academic Press, p. 487-544.

Wood, J.R., and Hewett, T.A., 1984, Reservoir diagenesis and convective fluid flow, in McDonald, D.A., and Surdam, R.C., eds., Clastic diagenesis: American Association of Petroleum Geologists Memoir 37, p. 99-110. 


\title{
Natural Gas
}

\author{
By Keith A. Kvenvolden
}

Natural gas is commonly defined as the gaseous phase of petroleum, but microbial gas, which has no direct connection with petroleum, is also referred to as natural gas. The components of natural gas are mainly hydrocarbons of very low molecular weights accompanied by gaseous nonhydrocarbons such as carbon dioxide, nitrogen, hydrogen sulfide, helium, and hydrogen. In a typical reservoir, natural gas contains 70 to 100 percent methane, 1 to 10 percent ethane, and lower percentages to trace amounts of higher molecular weight hydrocarbons up to about nonane (Hunt, 1979). Natural gas composed almost entirely of methane is called a dry gas; if the proportion of ethane and larger hydrocarbons exceeds about 4 percent, the mixture is called a wet gas. The terms sweet and sour refer to the low or high content of hydrogen sulfide. Wherever natural gas accompanies oil, the gas is called an associated gas; if the gas no longer accompanies oil, the gas is called a nonassociated gas.

The components of natural gas have multiple sources, but the dominant hydrocarbon components result from the alteration or degradation of organic matter in fine-grained sediment or sedimentary rocks by a series of complex chemical reactions (Rice and Claypool, 1981). The extent of these reactions is controlled primarily by temperature and duration of heating during geologic time. The processes of formation of natural gas take place during three stages of increasing chemical alteration (maturity) called diagenesis, catagenesis, and metagenesis (Tissot and Welte, 1984).

During diagenesis, both biochemical and thermochemical processes take place, but because of the low temperatures involved $\left(<50{ }^{\circ} \mathrm{C}\right)$, only biochemical processes are geologically significant, generating extensive volumes of microbial methane through methanogenesis. More than 20 percent of the world's discovered gas reserves are of microbial origin (Rice and Claypool, 1981).

With increasing temperatures and advancing geologic time, a full range of hydrocarbons in natural gas is produced from the thermal alteration of organic matter during the maturation stage of catagenesis. This stage is the principal one for oil generation, during which significant amounts of wet natural gas are produced from the alteration of organic matter (kerogen) as well as from the alteration of previously formed oil.

At the end of the catagenesis stage, kerogen becomes highly polymerized and stable. With increasing temperatures and time during the metagenesis stage, methane alone results from the high-temperature cracking of remaining hydrocarbons, because hydrocarbons larger than methane are destroyed much more rapidly than they are formed (Rice and Claypool, 1981).

Thus dry natural gas (mainly methane) is generated during the maturity stages of diagenesis and metagenesis whereas wet natural gas (methane plus larger molecules) is formed during catagenesis. Methane resulting from various processes can be distinguished by measurements of its carbon and often its hydrogen isotopic compositions. The range of carbon isotopic compositions of methane in commercial natural gas deposits range from about -75 to -25 permil relative to the Peedee Belemnite Standard (Fuex, 1977). The limits on this range are not fixed. Within this range, methane at various maturity stages has specific isotopic signatures.

When methane is formed microbially, two primary methanogenic pathways can be distinguished using carbon and hydrogen isotopic compositions of this gas (Whiticar and others, 1986). Although both pathways may occur in both marine and freshwater sediment, carbon dioxide reduction to form methane is the dominant pathway in the sulfate-free zone of marine sediment, whereas acetate-type fermentation is the principal pathway in freshwater sediment. Methane in marine sediment has isotopic compositions ranging from -110 to -60 permil for carbon and from -250 to -170 permil for hydrogen. (Hydrogen isotopic compositions are reported relative to standard mean ocean water, SMOW). In contrast, methane from freshwater sediment ranges from -65 to -50 permil for carbon and from -400 to -250 permil for hydrogen. Methane in shallow dry gas deposits worldwide has carbon isotopic compositions ranging from about -85 to -55 permil (Rice and Claypool, 1981).

Methane formed during catagenesis is commonly referred to as thermogenic gas. The carbon isotopic composition of this methane ranges between about -60 and -40 permil (Fuex, 1977) and the hydrogen isotopic composition from about -300 to -140 permil (Schoell, 1983). Most natural wet gas deposits in the world contain thermogenic methane (Hunt, 1979).

Metagenic gas is dry gas formed at temperatures in excess of about $150^{\circ} \mathrm{C}$. The isotopic compositions of methane formed during metagenesis ranges from about -40 to -20 permil for carbon and from -150 to -130 permil for hydrogen (Tissot and Welte, 1984). The 
isotopic signatures of methane and other hydrocarbons in natural gas along with molecular compositions of the gas mixtures provide means by which natural gases can be characterized genetically (Schoell, 1983). Such characterization is valuable in petroleum exploration, allowing an assessment of source, origin, and migration of natural gas.

Proved and currently recoverable world resources of conventional natural gas have been estimated to be 2,329 to 2,594 trillion cubic feet (tcf) or $6.6 \times 10^{13}$ to $7.3 \times 10^{13} \mathrm{~m}^{3}$, and the estimated total remaining recoverable resources are 7,900 to 9,200 tcf or $2.2 \times 10^{14}$ to $2.6 \times 10^{14} \mathrm{~m}^{3}$ (Parent, 1980). Besides these conventional natural gas deposits, a large potential natural gas resource exists within reservoirs that are not producible with conventional drilling and production techniques. These reservoirs of nonconventional natural gas include geopressured aquifers, coal seams, organicrich shales, tight sands, and gas hydrates. In recent years, interest in the potential supply of natural gas from nonconventional sources has increased as has information about them through studies supported by the Department of Energy. Improvements in drilling and production technology accompanied by a more favorable economic climate will likely make it possible in the future to recover significant volumes of natural gas from some of these sources (Potential Gas Committee, 1981).

\section{REFERENCES CITED}

Fuex, A.N., 1977, The use of stable carbon isotopes in hydrocarbon exploration: Journal of Geochemical Exploration, v. 7, p. 155-188.

Hunt, J.M., 1979, Petroleum geochemistry and geology: San Francisco, W.H. Freeman, 617 p.

Parent, J.D., 1980, A survey of the United States and total world production, proved reserves, and remaining recoverable resources of fossil fuels and uranium: Chicago, The Institute of Gas Technology, $140 \mathrm{p}$.

Potential Gas Committee, 1981, Potential supply of natural gas in the United States (as of December 31, 1980): Potential Gas Agency, Golden, Colorado, Colorado School of Mines, 119 p.

Rice, D.D., and Claypool, G.E., 1981, Generation, accumulation, and resource potential of biogenic gas: American Association of Petroleum Geologists Bulletin, v. 65 , p. 5-25.

Schoell, M., 1983, Genetic characterization of natural gases: American Association of Petroleum Geologists Bulletin, v. 67, p. 2225-2238.

Tissot, B.P., and Welte, D.H., 1984, Petroleum formation and occurrence-A new approach to oil and gas exploration: Berlin, Springer-Verlag, 538 p.

Whiticar, M.J., Faber, E., and Schoell, M., 1986, Biogenic methane formation in marine and freshwater environments: $\mathrm{CO}_{2}$ reduction vs. acetate fermentation-Isotopic evidence: Geochimica et Cosmochimica Acta, v. 50, p. 693-709. 


\title{
Natural Gas Hydrate
}

\author{
By Timothy S. Collett and Keith A. Kvenvolden
}

Gas hydrates are a type of inclusion compound or clathrate formed as icelike mixtures of gas and water in which gas molecules are contained within a solid cage framework of water molecules. Large quantities of natural gas, mainly methane, can be trapped in sediments in the form of gas hydrates. The necessary pressure and temperature conditions for the formation of gas hydrates are found at high latitudes in permafrost regions and at low and high latitudes in oceanic sediment of outer continental margins and ocean basins (reviewed by Kvenvolden and McMenamin, 1980). Gas hydrates can be expected to occur in these two regions wherever the supply of methane from microbial and thermogenic sources is sufficient to stabilize the gas hydrate structure. In practical terms, gas hydrates of permafrost regions can occur at subsurface depths ranging from about 130 to $2,000 \mathrm{~m}$, depending on subsurface temperatures. In sediment of outer continental margins, at water depths exceeding 300 to $500 \mathrm{~m}$, gas hydrates can occur near the bottom to sub-bottom depths of about $1,000 \mathrm{~m}$; these limits depend on bottom-water temperatures and geothermal gradients.

An attractive aspect of gas hydrates as a potential energy resource is that they may contain or trap enormous volumes of methane at shallow subsurface depths. One volume of gas hydrate may hold about 164 volumes of methane (Davidson and others, 1978). At depths less than about $1,300 \mathrm{~m}$, gas hydrates contain more gas than can be trapped in an equal volume of free space. At greater depths there is no volumetric advantage to gas hydrates (reviewed by Hunt, 1979). An important asset of gas hydrates may be their impermeability, which provides a barrier or seal under which free gas can accumulate (Hedberg, 1980).

Although the greatest volume of methane occurs in gas hydrates of outer continental margins, it is the gas hydrates of permafrost regions that are of greatest exploration interest because these potential gas deposits occur on land and not beneath great water depths. During the 1940's, the pressure and temperature conditions in permafrost regions were recognized as appropriate for gas-hydrate occurrence (Katz, 1971). By 1970, well logging and formation tests in the Messoyakha gas field of western Siberia conclusively showed the presence of gas hydrates (Makogon and others, 1972); in fact, this was the first gas hydrate field where an attempt was made to produce gas from the hydrate commercially. Besides the western Siberia platform, where the Messoyakha gas field is located, other permafrost areas of the northern USSR, including the Timan-Pechora province, the eastern Siberian craton, and the northeastern USSR and Kamchatka areas, are believed to have gas hydrate deposits (Cherskiy and others, 1985).

The occurrences of permafrost-associated gas hydrates in the North American Arctic have been reviewed by Kvenvolden and Grantz (in press). Well-log responses consistent with the presence of gas hydrates were obtained in the Mackenzie Delta, Sverdrup Basin, Arctic Platform and Islands, and the North Slope of Alaska. The only known confirmation of the presence of inplace natural gas hydrates on the North Slope of Alaska was obtained in 1972, when Arco and Exxon were successful in recovering samples of gas hydrates in pressure-core barrels (reviewed by Collett and Kvenvolden, 1987). These samples came from a well located about $10 \mathrm{~km}$ west of the giant Prudhoe Bay oil field.

A study of wire-line logs from 134 wells from the North Slope of Alaska indicates possible gas hydrates in 39 of these wells (Collett, 1983; Collett and others, 1988). The depths between which the occurrence of gas hydrate is inferred from well logs range from 130 to $1,100 \mathrm{~m}$. Most of the gas hydrates appear to be geographically restricted to the Kuparuk River area. Gas hydrates there occur in about four to six laterally continuous units. The gas hydrates are restricted to a series of sandstones and conglomerates that are interbedded with multiple thick siltstone units. The gashydrate-bearing sandstones and conglomerates represent a nonmarine delta-front to delta-plain depositional package.

Resource estimates for gas hydrates are variable and highly speculative owing to incomplete knowledge of gas hydrate occurrences and poor methods for estimating reserves in known occurrences; the Potential Gas Committee (1981) summarized such estimates. For continental Alaska, estimates of the volume of natural gas in gas hydrates ranges from 11 to 25,000 trillion cubic feet (tcf) or $3.1 \times 10^{11}$ to $7,100 \times 10^{11} \mathrm{~m}^{3}$. The actual value is probably nearer the lower limit of this range.

Although the amount of methane in gas hydrates is undoubtedly large, current technology cannot extract hydrated gas economically even if production wells are able to drill into the gas hydrates (Franklin, 1980). Penetration of gas hydrates during drilling may be hazardous; however, special procedures including slow 
drilling rates and carefully controlled mud weights and temperatures have proved to be successful in wells located in the Canadian Beaufort Sea (Weaver and Stewart, 1982).

Current research on gas hydrates in Alaska is directed toward detailing the geologic setting and formational characteristics of these deposits through temperature and borehole gravity surveys, analyses of pore fluids, field mapping and sampling, and seismic modeling. Goals of the work are to verify the presence of gas hydrates in this region through core recovery, to develop a model for gas hydrate formation and occurrence on the North Slope, to determine the amount of methane that is associated with these gas hydrates, and to establish the potential for these gas hydrate deposits as unconventional energy resources.

\section{REFERENCES CITED}

Cherskiy, N.V., Tsarev, V.P., and Nikitin, S.P., 1985, Investigation and prediction of conditions of accumulation of gas resources in gas hydrate pools: Petroleum Geology, v. 21, p. 65-89.

Collett, T.S., 1983, Detection and evaluation of natural gas hydrates from well logs, Prudhoe Bay, Alaska: Fairbanks, University of Alaska, M.S. thesis, $78 \mathrm{p}$.

Collett, T.S., Bird, K.J., Kvenvolden, K.A., and Magoon, L.B., 1988, Geologic interrelations relative to gas hydrates within the North Slope of Alaska: U.S. Geological Survey Open-File Report 88$389,150 \mathrm{p}$.

Collett, T.S., and Kvenvolden, K.A., 1987, Evidence of naturally occurring gas hydrates on the North Slope of Alaska: U.S. Geological Survey OpenFile Report 87-255, 8 p.

Davidson, D.W., El-Defrawy, M.K., Fuglem, M.O., and Judge, A.S., 1987, Natural gas hydrates in northem Canada: Proceedings Third International Conference on Permafrost, v. 1, p. 937-943.
Franklin, L.J., 1980, In-situ hydrates-A potential gas source: Petroleum Engineering International, v. 52 , no. 13 , p. 112-122.

Hedberg, H.D., 1980, Methane generation and petroleum migration, in Roberts, W.H., III, and Cordell, R.J., eds., Problems of petroleum migration: American Association of Petroleum Geologists Studies in Geology 10, p. 179-206.

Hunt, J.M., 1979, Methane hydrates, in Hunt, J.M., Petroleum geochemistry and geology: San Francisco, W.H. Freeman, p. 156-162.

Katz, D.L., 1971, Depths to which frozen gas fields (gas hydrates) may be expected: Journal of Petroleum Technology, v. 23, p. 419-423.

Kvenvolden, K.A., and Grantz, Arthur, in press, Gas hydrates of the Arctic Ocean region, in Grantz, A., Johnson, L., and Sweeney, J.F., eds., The Arctic Ocean region: Boulder, Geological Society of America, Geology of North America series, v. 50.

Kvenvolden, K.A., and McMenamin, M.A., 1980, Hydrates of natural gas: A review of their geologic occurrences: U.S. Geological Survey Circular 825, $11 \mathrm{p}$.

Makogon, Yu.F., Trebin, F.A., Trofimuk, A.A., Tsarev, V.P., and Cherskiy, N.V., 1972, Detection of a pool of natural gas in a solid (hydrate gas) state: Doklady-Earth Science Section 196, p. 197-200.

Potential Gas Committee, 1981, Potential supply of natural gas in the United States (as of December 31, 1980): Golden, Colorado, Potential Gas Agency, Colorado School of Mines, $119 \mathrm{p}$.

Weaver, J.S., and Stewart, J.M., 1982, In-situ hydrates under the Beaufort Sea Shelf, in French, M.H., ed., Proceedings 4th Canadian Permafrost Conference, 1981 (Roger J.E. Brown Memorial Volume): National Research Council of Canada, p. 312-319. 


\title{
Tight Gas Reservoirs
}

\author{
By Ben E. Law and Charles W. Spencer
}

Low-permeability (tight) gas reservoirs are considered to have an estimated inplace gas permeability of 0.1 millidarcy (md) or less. Tight reservoirs contain major resources of gas; about 1 trillion cubic feet (tcf) of gas per year is produced from these reservoirs. The National Petroleum Council (1980) estimated the gas-inplace resource for tight reservoirs in the United States at about $924 \mathrm{tcf}$ and a maximum recoverable resource of about 608 tcf. This estimate is considered to be relatively conservative because reservoirs deeper than $4,600 \mathrm{~m}(15,000 \mathrm{ft})$ were not included in the assessment.

Tight-gas reservoirs are highly variable in terms of age, lithology, environments of deposition, depth, thickness, and continuity. They occur in nearly all petroleum provinces but are particularly notable in the eastern, south-central, and western regions of the United States.

In the eastern region, tight-gas reservoirs occur in the Appalachian and Black Warrior basins. The principal reservoirs are Devonian and Silurian shale, siltstone, and sandstone. The Devonian gas-bearing shales, which have been extensively studied (deWitt, 1986), are organic-rich, dark rocks that were deposited in a marine environment as the distal part of the Catskill delta system. The gas-bearing shales range in thickness from a few inches to more than $400 \mathrm{ft}$ and contain 0.5 to 20 weight percent organic carbon. Permeability ranges from 0.1 to 10 microdarcies $(\mu \mathrm{d})$, and porosity ranges from 1 to 3 percent. Most of the gas is adsorbed on organic matter, and a lesser amount occurs as free gas in fractures. Economic production from these reservoirs is highly dependent on the occurrence of natural fractures. The gas is generated from the shale and ranges from a biogenic origin in the western part of the Appalachian basin to a thermogenic origin in the eastern part of the basin.

The more important tight-gas sandstone reservoirs in the eastern region are the Lower Silurian Medina Group and Tuscarora Sandstone; the Devonian Oriskany Sandstone and Venango, Bradford, and Elk oil sand groups; and Mississippian Berea and Hartselle Sandstones (Laughrey and Harper, 1986; Finley, 1984, 1986). These sandstones were deposited in marine to marginal marine environments and are lithologically variable, ranging in composition from quartzose to feldspathic. Permeability is generally less than $0.1 \mathrm{md}$, and porosity ranges from 4 to 12 percent. As a result of a complex diagenetic history, most of the porosity is secondary. The pores are poorly connected, thus fractures, either natural or induced, are necessary for sustained flow rates.

In the south-central region, the tight-gas reservoirs occur in the Anadarko, Arkoma, East Texas, and North Louisiana basins. Reservoirs in these basins include sandstone and carbonate rocks of Pennsylvanian through Cretaceous age that were deposited in a wide range of marine to nonmarine environments. The more important tight-gas reservoirs in this region are the Lower Pennsylvanian (Morrowan) sandstones in the Anadarko basin, the Upper Jurassic Cotton Valley Formation in the East Texas and North Louisiana basins, and the Lower Cretaceous Travis Peak Formation in the East Texas basin. Reservoir characteristics of these and other units have been described by Finley $(1984,1986)$.

All of the units in the south-central region contain conventional as well as unconventional reservoirs. Permeability in the tighter portion of these reservoirs is well below $0.1 \mathrm{md}$, and porosity varies from 2 to 10 percent. Dissolution porosity is the primary type of porosity. Pressure conditions vary from normal to overpressured. Drilling depths to the tight Morrowan sandstone reservoirs in the Anadarko basin are generally greater than $4,600 \mathrm{~m}(15,000 \mathrm{ft})$ while depths to the Travis Peak and Cotton Valley in the East Texas and North Louisiana basins range from 900 to $3,350 \mathrm{~m}$ $(3,000-11,000 \mathrm{ft})$. The source of the gas in these reservoirs is unknown.

In the western region, tight-gas reservoirs occur in several Rocky Mountain foreland basins and in the Great Plains east of the Rocky Mountains. The reservoirs include Lower Cretaceous to lower Tertiary sandstone, siltstone, shale, and chalk that were deposited in marine to nonmarine environments. In the foreland basins, most of the reservoirs are Upper Cretaceous sandstone interbedded with siltstone, mudstone, and coal beds that were deposited in deltaic and fluvial systems that are as much as $3,000 \mathrm{~m}(10,000 \mathrm{ft})$ thick. The gas reservoirs are commonly overpressured or underpressured (Meissner, 1978; Law and Dickinson, 1985; Spencer, 1987), produce little or no water, and occur in basincenter positions, downdip from normal-pressured waterbearing reservoirs. The occurrence of these accumulations is largely determined by relationships between permeability, thermal maturation, temperature, pressure, and organic content; structural and stratigraphic trapping aspects are of secondary importance. The gas 
contained in these reservoirs is of thermogenic origin and was generated primarily from humic-type organic matter contained in the interbedded nonmarine organic-rich mudstone and coal beds and from adjacent marine shale (Law, 1984).

In the Great Plains region of eastern Colorado, northwestern Kansas, Nebraska, North and South Dakota, and eastern Montana, more than 100 tcf of recoverable gas resources is believed to be present (Rice and Shurr, 1980) in tight-gas reservoirs. Here, the reservoirs are composed of sandstone, siltstone, shale, and chalk. They were deposited in a shallow marine-shelf environment as blanketlike reservoirs and presently occur at depths generally less than $1,200 \mathrm{~m}(4,000 \mathrm{ft})$. Because of the generally small grain size, these reservoirs are characterized by relatively high porosity (15 to more than 20 percent) but with a low permeability to gas (Spencer, 1985). Gas in these reservoirs is of a biogenic origin and was generated from the adjacent shales (Rice and Shurr, 1980).

The U.S. Department of Energy and the Gas Research Institute have been sponsoring geologic and engineering research on tight-gas reservoirs for several years. Gas from tight reservoirs probably has the best potential for making a major near-term contribution to the Nation's energy needs. However, significant advancements in recovery technology are needed in order to maximize profitability and ultimate recovery.

\section{REFERENCES CITED}

deWitt, Wallace, Jr., 1986, Devonian gas-bearing shales in the Appalachian basin, in Spencer, C.W., and Mast, R.F., eds., Geology of tight gas reservoirs: American Association of Petroleum Geologists Studies in Geology 24, p. 1-8.

Finley, R.J., 1984, Geology and engineering characteristics of selected low-permeability gas sandstones-A national survey: University of Texas at Austin, Bureau of Economic Geology Report of Investigations 138, $220 \mathrm{p}$.

1986, An overview of selected blanket-geometry, low-permeability gas sandstones in Texas, in Spencer, C.W., and Mast, R.F., eds., Geology of tight gas reservoirs: American Association of Petroleum Geologists Studies in Geology 24, p. 69-85.
Laughrey, C.D., and Harper, J.A., 1986, Comparisons of Upper Devonian and Lower Silurian tight formations in Pennsylvania-Geological and engineering characteristics, in Spencer, C.W., and Mast, R.F., eds., Geology of tight gas reservoirs: American Association of Petroleum Geologists Studies in Geology 24, p. 9-43.

Law, B.E., 1984, Relationships of source-rock, thermal maturity, and overpressuring to gas generation and occurrence in low-permeability Upper Cretaceous and lower Tertiary rocks, Greater Green River basin, Wyoming, Colorado, and Utah, in Woodward, J., Meissner, F.F., and Clayton, J.L., eds., Hydrocarbon source rocks of the greater Rocky Mountain region: Denver, Rocky Mountain Association of Geologists, p. 469-490.

Law, B.E., and Dickinson, W.W., 1985, Conceptual model for origin of abnormally pressured gas accumulations in low-permeability reservoirs: American Association of Petroleum Geologists Bulletin, v. 69, p. 1295-1304.

Meissner, F.F., 1978, Patterns of source-rock maturity in nonmarine source-rocks of some typical Western Interior basins, in Nonmarine Tertiary and Upper Cretaceous source rocks and the occurrence of oil and basins west-central U.S.: Denver, Rocky Mountain Association of Geologists Continuing Education Lecture Series, p. 1-37.

National Petroleum Council, 1980, Tight gas reservoirs-Part I, in National Petroleum Council unconventional gas resources: Washington, D.C., National Petroleum Council, 222 p. with appendices.

Rice, D.D., and Shurr, G.W., 1980, Shallow lowpermeability reservoirs of the northern Great Plains-An assessment of their natural resources: American Association of Petroleum Geologists Bulletin, v. 64, no. 7, p. 969-987.

Spencer, C.W., 1985, Geologic aspects of tight gas reservoirs in the Rocky Mountain region: Journal of Petroleum Technology, v. 37, p. 1308-1314.

1987, Hydrocarbon generation as a mechanism for overpressuring in Rocky Mountain region: American Association of Petroleum Geologists Bulletin, v. 71, p. 368-388. 


\title{
Natural Gas in Fractured Shale-The Appalachian Devonian Black Shale Gas System
}

\author{
By John B. Roen
}

Fractured shale-gas systems are unconventional hydrocarbon accumulations in which the source and reservoir are the same tight shale beds. Such unconventional resources will increase in value as conventional resources decline and exploration and recovery techniques advance. For example, the recent energy shortage of the early 1970's prompted increased efforts in the exploitation of the gas contained in the fractured Devonian shale reservoirs in the Appalachian basin. The increased interest in the recovery of Devonian shale gas resulted in research that provided an excellent characterization and resource assessment of a fractured shale-gas system. Resource estimates suggest that 149 trillion cubic feet (tcf) (Wallace deWitt, oral commun., 1977) to $867 \mathrm{tcf}$ (Smith, 1978) of gas may be present in the black Devonian shales of the Appalachian area.

The Devonian gas shales are brownish black, grayish black, and black in color and are rich in organic matter. The average amount of organic carbon for the dark organic-rich shale ranges from about 10 weight percent in the western part of the basin to about 3 weight percent in the east. The average content of organic carbon in the fractured shale reservoir rock that produces gas is about 5 weight percent. The shales are concentrated in the western and central parts of the basin, although some crop out along the northern and eastern margins of the basin. The shales are very tight, having negligible porosity and extremely poor permeability.

Production decline curve characteristics from Devonian shale-gas wells substantiated by geochemical correlations indicate that the gas contained in the fractured Devonian black shale reservoirs was derived from the same black shale. The proven correlation of gas to source rock identifies a petroleum system: the Appalachian Devonian black shale gas system. The system is composed of several stratigraphic shale units, each of which could be identified as source and reservoir rock and hence each a discrete petroleum system with a known level of certainty. Because each of these systems is lithologically and geochemically identical to the others in the Devonian black shale sequence, it is reasonable to describe the sequence in its entirety as the Appalachian Devonian black shale gas systems(!); the exclamation point indicating a known level of certainty. As described, the system is purebred because its source rocks, migration paths, reservoir rocks, and trapping mechanisms are in the same basin.

Data from pyrolysis and elemental analysis plotted on van Krevelen diagrams indicate that the organic matter in the shales was derived from marine algae material (type I) and from terrestrial plants (type III). Limited data from ${ }^{13} \mathrm{C}$ nuclear magnetic resonance (NMR) analyses confirms the existence of both marine and terrestrial organic matter. The areal distribution of the NMR data suggests that the organic matter becomes increasingly terrestrial in character toward the east. Thermal maturation ranges from marginally mature in the western areas of shallow burial to postmature in the more deeply buried, eastern parts of the basin. Thermal alteration of the kerogen in the Devonian black shale generated oil in addition to substantial quantities of gas. Minor amounts of indigenous oil are being economically produced from the matrix and fractures of the Devonian black shale gas system in north-central West Virginia and adjacent southeastern Ohio. The presence of oil, however, is thought to inhibit the slow migration of the gas molecules through the shale matrix to fractures and permeability paths to the well bore (Soeder and others, 1986). Oil trapped in sandstone reservoirs stratigraphically above the Devonian black shale is believed to have been derived from the black shale (George Claypool, written commun., 1984). The oil was probably derived from source beds with comparatively higher concentrations of oil-prone, type I kerogens. Its generation and migration probably occurred early relative to the shale gas. The relative amount and type of recovered hydrocarbons generated from the shales and the amount and type of hydrocarbons estimated to be remaining in place, supported by the aforementured geochemical and pyrolytic analyses, suggest that the shales are predominantly gas prone.

Production of gas from Devonian shale reservoirs is dependent on the existence of naturally occurring fracture systems. Without extensive natural fractures, the shale gas molecules cannot desorb from the very low permeability shale matrix, move to the fracture system and ultimately to the well bore in quantities sufficient for economic exploitation. Shale sequences lacking extensive natural fracture systems generally will not yield gas economically, even with stimulation by existing fracturing techniques. Natural fracturing of the Devonian shale gas system is the result of tensional 
tectonic features of the Appalachian basin. Faulting associated with the Rome trough, a portion of a basement aulacogen (Harris, 1978), and the Kentucky River-Paint Creek fault zone has created an extensive fracture reservoir system in the shale. Glacial retreat and subsequent crustal rebound due to weight removal have produced fractures in gas-rich shales to a depth of about $450 \mathrm{~m}(1,500 \mathrm{ft})$. Tensional fractures resulting from compressional tectonics in folding also produce the necessary fracture porosity and permeability. However, shear fractures from horizontal compressional stress apparently do not produce the required extensive fracture porosity and permeability necessary for economic concentration of shale gas. This is evidenced by very short duration blowouts and the lack of sustained steady production from an extremely fractured décollement zone in the Devonian black shale sequence along the Pine Mountain thrust fault.

Studies of the Devonian black shale gas system indicate that several of its features are probably common to other fractured shale gas systems. It is apparent that the existence of an extensive natural fracture system with enhancement is a prerequisite for economic exploitation. The natural fractures in a fractured shale system should be tensional in nature. In fractured shale gas systems, the hydrocarbons that are produced are generally indigenous to the fractured shale reservoir rock. Production decline curves of wells in fractured shale systems display similar characteristics of initial flush production declining at a rapid rate before reaching a relatively much longer period of steady-state flow. Finally, fractured gas shale reservoirs are not easily located by the more conventional exploration techniques; in fact, most discoveries were the results of random drilling.

In regard to exploration, new and successful techniques must be developed to fully utilize the gas resource contained in the Devonian as well as other fractured shale gas systems. Recently, research efforts have concentrated on various surface techniques to locate prospective areas. Efforts have been directed to locating areas with a high density of penetrative fractures and joints that might be indicative of a similar concentration of fractures in a Devonian shale reservoir at depth. Delineation of major stress systems, field mapping of joints and fractures, and the use of various remote sensing methods have been used with moderate success. Further development in the application of remote sensing techniques is needed. In addition, research is needed in the application and utility of direct and indirect geochemical detection to delineate extensive fracture systems.
Improvement of Devonian shale development techniques have also been under investigation. Various downhole diagnostic methods, including borehole television examination and wire-line geophysical characterization, have been developed along with application of stratigraphic, geochemical, and production data to define closely the stratigraphic shale intervals for completion and stimulation. Research on stimulation techniques to increase yield and flow rate has been carried out looking for improvement and new methods. Early stimulation methods with explosives commonly created good gas flow but required extensive clean-up periods. Shooting shale-gas wells has been largely replaced by hydraulic fracturing techniques developed in the 1950's. Hydraulic fracturing, with subsequent improvements and modifications, has been most widely and successfully used. However, the use of water as the fracturing fluid causes swelling of some mixed-layer clays in the shale, which reduces permeability and blocks gas migration to the well bore. Difficulties from the excessive volume of water in the fracturing treatment have been largely overcome by more recently developed foam fracturing methods that use nitrogen and considerably less water than the hydraulic method.

Current research is principally confined to developing downhole diagnostic techniques and relating stratigraphic characteristics to production in order to enhance the selection and development of the most productive shale interval.

\section{REFERENCES CITED}

Harris, L.D., 1978, The Eastern interior aulacogen and its relation to Devonian shale gas production: Second Eastern Gas Shales Symposium, U.S. Department of Energy, Morgantown Energy Technology Center, Preprint, METC/SP-78/6, v. 2, p. 55-73.

Smith, E.C., 1978, A practical approach to evaluating shale hydrocarbon potential: Second Eastern Gas Shales Symposium, U.S. Department of Energy, Morgantown Energy Technology Center, Preprint, METC/SP-78/6, v. 2, p. 73-87.

Soeder, D.J., Randolph, P.L., and Matthews, R.D., 1986, Porosity and permeability of Eastern Devonian gas shales: U.S. Department of Energy, Morgantown Energy Technology Center, Report DOE/MC/20343-8, p. 52-54. 


\title{
Coal-Bed Methane
}

\author{
By Ben E. Law
}

Coal beds have been known or assumed to be excellent sources of gas for many years. There is a growing awareness, however, that coal beds are also good gas reservoirs; gas generated and stored in coal beds can be recovered with standard petroleum drilling and production techniques. In Europe and in the eastern United States, coal-bed gas has been produced and utilized in limited quantities for many years, and, recently, coal-bed gas has been produced from coal beds in the western United States. Several areas in the United States, most notably the Black Warrior basin in Alabama and the San Juan basin in New Mexico and Colorado, are now producing commercial quantities of gas from coal beds. Coal-bed methane resources in the United States are estimated at 72 to 860 trillion cubic feet (tcf), and most estimates are between 300 and 500 tcf (Rightmire, 1984).

Coal is a lithified organic sediment derived from various types of plant material that form under a wide variety of physical and chemical conditions. Most coal is composed of woody plant debris and is generally thought to be capable of generating mainly gas with lesser amounts of oil (Tissot and Welte, 1984; Hunt, 1979), although some work has suggested that a significant amount of coal-derived hydrocarbons consist of oil-type components (Durand and Parratte, 1983). During early stages of coalification (diagenesis), coal beds are affected by microorganisms in predominantly low-temperature environments. Methane, carbon dioxide, and traces of other gases are released, as well as large amounts of water. With increasing burial, coal beds are subjected to higher temperature and pressure environments (catagenesis). Under these conditions, large amounts of methane and carbon dioxide and smaller amounts of nitrogen, oxygen, hydrogen, and heavier hydrocarbons, such as ethane, propane, and butane, are generated. During catagenesis, it has been estimated that more than $200 \mathrm{~m}^{3}\left(7,000 \mathrm{ft}^{3}\right)$ of gas may be generated from 1 ton $(900 \mathrm{~kg}$ ) of coal (Juntgen and Karweil, 1966). Although some of this gas either is lost to the atmosphere or migrates from the coal into adjacent rocks, large quantities are retained in the coal as free gas within joints or fractures in the coal or as adsorbed gas within the fine micropore coal structure (Stach and others, 1982). Gas contained in joints and fractures is more easily removed from the coal than is the more abundant adsorbed gas. At constant temperature and pressure, high-rank coals contain larger amounts of gas

than low-rank coals. The gas adsorption capability of coal increases with increasing pressure and decreases with increasing temperature (Kim, 1977). Coal-bed gas contains 90 to 99 percent methane and has a heat of combustion of 950 to $1,035 \mathrm{Btu}$ per cubic foot.

At the present time, coal-bed gas is produced from deep, unminable seams, from drainage of gas in advance of coal mining, and from drainage of gas from mined-out areas. Production rates are highly variable. Initial daily rates from some of the better producing wells are more than 1 million cubic feet $\left(28,000 \mathrm{~m}^{3}\right)$ per day, but rates in most wells are less than $250,000 \mathrm{ft}^{3} / \mathrm{d}$ $\left(7,000 \mathrm{~m}^{3}\right)$. Physicochemical factors affecting the amount and recoverability of coal-bed gas include coal rank, moisture content, gas adsorption capability, macropore and micropore structure, cleat (or fracture) development, type of organic matter, temperature, and pressure.

Although there is a large base of knowledge concerning many aspects of coal, most of that information is applicable to the mining industry and the direct utilization of coal. From a petroleum geology perspective, relatively little information is directly applicable. Some of the more important geologic uncertainties that need additional work include: (1) determining the factors controlling the amount of water in coal-bed reservoirs; (2) refining the relations between reservoir pressure, temperature, thermal maturity, and gas production; (3) determining the importance of cleat development to gas production; (4) determining the importance of coal-bed composition to coal gassiness; and (5) conducting basin-wide burial and thermal history reconstructions of coal beds.

Coal beds have some advantages over conventional gas reservoirs. Geographic and stratigraphic occurrences of coal beds in the United States and elsewhere are relatively well known, and, because the coal beds are both the gas source and the gas reservoir, problems of gas generation and migration are less complex. These factors, in conjunction with drilling depths of generally less than $900 \mathrm{~m}(3,000 \mathrm{ft})$, reduce exploration and exploitation costs.

The commonly employed methods of gas recovery from coal beds are vertical drilling using standard petroleum techniques and directional drilling. Vertically drilled holes drain the gas from the area immediately adjacent to the borehole. This type of completion often requires additional stimulation 
treatment to increase production to economic levels. Fracturing the coal bed by injection of fluids under pressure is a common practice. These hydraulic fractures generally increase the effective drainage area and significantly increase production levels. Directional drilling is a technique used to drill a hole within and parallel to a coal bed. The coal bed may be horizontal or steeply dipping. This technique maximizes the coal surface area exposed to the borehole, intersecting the joint system of the coal and thereby exposing a large area of gas drainage.

\section{REFERENCES CITED}

Durand, B., and Parratte, M., 1983, Oil potential of coals-A geochemical approach, in Brooks, V., ed., Petroleum geochemistry and exploration of Europe: Geological Society Special Publication 12, p. 255-265.

Hunt, J.M., 1979, Petroleum geochemistry and geology: San Francisco, W.H. Freeman, 617 p.
Juntgen, H., and Karweil, J., 1966, Gasbildung und gasspeicherung in steinkohlenflozen, Part I and II: Erdol and Kohle, Erdgas, Petrochemie, v. 19, p. 251-258 and p. 339-344.

Kim, A.G., 1977, Estimating methane content of bituminous coalbeds from adsorption data: U.S. Bureau of Mines Report of Investigations 8245, $22 \mathrm{p}$.

Rightmire, C.T., 1984, Coalbed methane resource, in Rightmire, C.T., Eddy, G.E., and Kirr, J.N., eds., Coalbed methane resources of the United States: American Association of Petroleum Geologists Studies in Geology 17, p. 1-13.

Stach, C., Chamdra, D., Mackowsky, M-Th., Taylor, G.H., Teichmueller, M., and Teichmueller, R., 1982, Stach's text book of coal petrology: Stuttgart, Borntraeger, $428 \mathrm{p}$.

Tissot, B.P., and Welte, D.H., 1984, Petroleum formation and occurrence: New York, Springer-Verlag, $699 \mathrm{p}$. 


\title{
Classification and Composition of Crude Oil
}

\author{
By Jerry L. Clayton
}

Several methods for classification of crude oils have been proposed by geochemists and refining chemists using physical characteristics or chemical composition of oils. The various schemes that have been developed have different purposes and are based on different physical and chemical parameters. The reader is referred to Tissot and Welte (1984) for a historical review of various petroleum classification methods. Geologists and geochemists view classification as a means to relate oils to their source rocks and to determine their level of thermal maturation. Such an understanding is critical for determining relationships between oils and source beds, for determining the generation and migration history of hydrocarbons, and for prediction of recoverable reserves within the petroleum system. Unfortunately, in many cases the source rocks are unknown and only crude oils are available for analysis. This paper is a summary of the most common approaches to classification of oils for the purpose of interpreting the nature of the source rock. The most basic level of classification of oils with respect to source is to distinguish carbonate- and shale-derived oils and to separate marine from nonmarine oils. Distinctions can be made between marine and nonmarine oils as well as including more specific depositional settings within these two broad categories. Palacas (this volume) summarizes the classification parameters for oils derived from carbonate versus shale sources.

Crude oil ranges from heavy oil to condensate. It is a complex mixture of predominantly hydrocarbons with secondary amounts of nonhydrocarbons (heteroatomic molecules) containing $\mathrm{N}, \mathrm{S}$, or $\mathrm{O}$. Hydrocarbons typically constitute greater than 75 to 80 percent by weight of medium-gravity crude oil. Medium-gravity oils are defined for the purpose of this discussion as those with API gravity between $20^{\circ}$ to $45^{\circ}$. Condensates are included in this paper and are defined as oils that are gases at the pressure and temperature of the reservoir, but are liquids at surface temperature and pressure. Condensates have API gravities of approximately $45^{\circ}$ or higher. Unfortunately, some ambiguity is introduced by this definition because it depends on reservoir conditions rather than actual composition of the reservoir fluids. Changes in reservoir pressure during the geologic or development history of a reservoir can change a gaseous condensate into a liquid accumulation. Oils with API gravities between $10^{\circ}$ and $20^{\circ}$ are generally classified as heavy oils, and those with gravities less than $10^{\circ}$ are called extra-heavy (Connan, 1984). Heavy and extra-heavy oils are discussed in a separate report (Meyer, this volume) and are not specifically addressed here.

Generally, a classification based on density or boiling-point distribution may be useful for refinery applications, but has limited application for exploration geologists or geochemists who need to know something about the specific source beds and conditions of formation for petroleum accumulations. Although normal oils $\left(20^{\circ}-45^{\circ}+\right.$ API gravity) are composed predominantly of saturated and aromatic hydrocarbons with secondary amounts of nonhydrocarbons (resins and asphaltenes), the actual abundances of various structural types, indicated in table 9, can vary considerably. More importantly, the molecular distribution within the various structural types of compounds can vary widely in response to differences in the thermal maturities of various oils and, particularly, the parent-source organic matter from which the oils were derived. Because explorationists are interested in the source of an oil, compounds which provide source-specific information about the oil are important in the classification, even though they may be present only in small amounts in the oil. Recently, Tissot and Welte (1984) proposed a

Table 9. Typical composition of a $35^{\circ}$ API gravity crude oil (from Hunt, 1979)

\begin{tabular}{lcr}
\hline $\begin{array}{c}\text { Common } \\
\text { name }\end{array}$ & $\begin{array}{c}\text { Molecular } \\
\text { weight } \\
\text { range }\end{array}$ & $\begin{array}{r}\text { Volume } \\
\text { percent }\end{array}$ \\
\hline Gasoline & $\mathrm{C}_{5}-\mathrm{C}_{10}$ & 27 \\
Kerosene & $\mathrm{C}_{11}-\mathrm{C}_{13}$ & 13 \\
Diesel fuel & $\mathrm{C}_{14}-\mathrm{C}_{18}$ & 12 \\
Heavy gas oil & $\mathrm{C}_{19}-\mathrm{C}_{25}$ & 10 \\
Lubricating oil & $\mathrm{C}_{26}-\mathrm{C}_{40}$ & 20 \\
Residuum & $>\mathrm{C}_{40}$ & 18 \\
& & Total 100 \\
\hline \multicolumn{1}{c}{ Molecular } & & Weight \\
$\quad$ types & & percent \\
\hline Paraffins & & 25 \\
Naphthenes & & 50 \\
Aromatics & & 17 \\
Asphaltenes + resins & & Total 100 \\
\cline { 2 - 3 } & &
\end{tabular}


Table 10. Classification of oils according to scheme of Tissot and Welte (1984)

$\left[\mathrm{S}\right.$, saturates; AA, aromatics + resins + asphaltenes; $\mathrm{P}$, parafins; $\mathrm{N}$, naphthenes; $>210^{\circ} \mathrm{C}$, concentration in crude oil topped at $\left.210^{\circ} \mathrm{C}\right]$

\begin{tabular}{lllrr}
\hline $\begin{array}{c}\text { Concentration in crude oil } \\
>210^{\circ} \mathrm{C}\end{array}$ & \multicolumn{1}{c}{$\begin{array}{c}\text { Crude oil } \\
\text { type }\end{array}$} & $\begin{array}{c}\text { Sulfur content } \\
\text { in crude oil } \\
\text { (approximate) }\end{array}$ & $\begin{array}{c}\text { Number of } \\
\text { samples per class } \\
\text { (total no. 514) }\end{array}$ \\
\hline $\mathrm{S}>50 \%, \mathrm{AA}<50 \%$ & $\mathrm{P}>\mathrm{N}$ and $\mathrm{P}>40 \%$ & Paraffinic & $<1 \%$ & 100 \\
$\mathrm{~S}>50 \%, \mathrm{AA}<50 \%$ & $\mathrm{P} \leq 40 \%$ and $\mathrm{N} \leq 40 \%$ & Paraffinic-naphthenic & $<1 \%$ & 217 \\
$\mathrm{~S}>50 \%, \mathrm{AA}<50 \%$ & $\mathrm{~N}>\mathrm{P}$ and $\mathrm{N}>40 \%$ & Naphthenic & $>1 \%$ & 21 \\
$\mathrm{~S} \leq 50 \%, \mathrm{AA}>50 \%$ & $\mathrm{P}>10 \%$ & Aromatic-intermediate & $>1 \%$ & 126 \\
$\mathrm{~S} \leq 50 \%, \mathrm{AA} \geq 50 \%$ & $\mathrm{P} \leq 10 \%, \mathrm{~N} \leq 25 \%$ & Aromatic-asphaltic & Generally $\mathrm{S}<1 \%$ & 41 \\
$\mathrm{~S} \leq 50 \%, \mathrm{AA} \geq 50 \%$ & $\mathrm{P} \leq 10 \%, \mathrm{~N} \geq 25 \%$ & Aromatic-naphthenic & & 36 \\
\hline
\end{tabular}

classification scheme based on the content of normal + isoalkanes, cycloalkanes, and aromatic compounds, including resins and asphaltenes. Table 10 shows the main classes of oils according to their scheme. Some genetic information is included in this scheme. "Aromatic-intermediate" oils are generally associated with marine sediments and reducing conditions, and "paraffinic-naphthenic" or "paraffinic" oils are usually associated with deltaic sediments of continental margins or nonmarine source rocks.

Silverman and Epstein (1958) suggested that stable carbon isotope ratios could be used to separate marine from nonmarine oils. More recently, Sofer (1984) determined carbon isotope ratios of saturated and aromatic hydrocarbons for 339 oils and concluded that oils derived from marine and nonmarine organic matter could be distinguished not by carbon isotope composition of a particular fraction but by the difference in isotope ratios between the saturated and aromatic hydrocarbons. Schoell $(1983 ; 1984)$ used carbon and hydrogen isotopes to differentiate carbonate- and shale-derived oils. Peters and others (1986) argued that carbon isotopes cannot be used to unequivocally separate marine and nonmarine oils. They suggested that multivariate analysis of a combination of biological marker and isotope data provides a better method for distinguishing depositional settings of source rocks based on oil analyses, and presented data showing classification of oils from marine shale, nonmarine shale, and marine carbonates.

With continuing development of analytical capabilities and computerized handling of data, various classification methods using the multivariate approach are becoming more popular, and, in some cases, more details about the source-rock geochemistry may be inferred from oil analyses. For example, Moldowan and others (1985) were able to differentiate marine from nonmarine oils in a sample set of 40 oils using $C_{30}$ steranes and monoaromatic steroid distributions and were able to estimate the relative proportion of higher plant input for a given crude. Mello and others (1988) used a combination of geochemical methods (carbon isotope ratios, API gravity, $\mathrm{Ni} / \mathrm{V}$, percent sulfur, biological markers) to classify oils from offshore Brazil as to depositional settings of the source rocks-lacustrine freshwater, lacustrine saline, marine evaporites, marine carbonate, or marine deltaic. Zumberge (1987) used statistical analysis of geochemical data (16 biological marker compounds) to classify 216 oils located worldwide for the purpose of predicting source-rock features or depositional environments. He identified five categories of oil (source-rock depositional setting): nearshore marine (paralic/deltaic); deeper-water marine; lacustrine; phosphatic-rich source beds; and Ordovician age source beds.

For very mature oils, particularly condensates, classification according to type of source rock is more difficult than for normal-gravity oils because severe thermal alteration of source-specific parameters may have occurred. The overall trend of increasing maturity is to reduce the chemical complexity of an oil and produce oils with fewer and simpler chemical structures. Given sufficient temperature over geologic time, only methane would be present in significant quantities.

Future methods of classification of oils will undoubtedly use a multiparameter approach and will depend heavily on the use of individual biomarker compounds or associations of several biomarkers and bulk properties for inferring detailed information about the source environment of the parent organic matter of the oils.

\section{REFERENCES CITED}

Connan, J., 1984, Biodegradation of crude oils in reservoirs, in Brooks, J., and Welte, D., eds., Advances in petroleum geochemistry, v. 1: New York, Academic Press, p. 299-335.

Hunt, J.M., 1979, Petroleum geochemistry and geology: San Francisco, W. H. Freeman, 617 p. 
Mello, M.R., Gaglianone, P.O., Brassell, S.C., and Maxwell, J.R., in press, Geochemical and biological marker assessment of depositional environments using Brazilian offshore oils, in Mattavelli, L., and Novelli, L., eds., Advances in organic geochemistry 1987: Organic Geochemistry.

Moldowan, J.M., Seifert, W.K., and Gallegos, E.J., 1985, Relationship between petroleum composition and depositional environment of petroleum source rocks: American Association of Petroleum Geologists Bulletin, v. 69, p. 1255-1268.

Peters, K.E., Moldowan, J.M., Scholle, M., and Hempkins, W. B., 1986, Petroleum isotopic and biomarker composition related to source rock organic matter and depositional environment, in Leythaeuser, D., and Rullkötter, J., eds., Advances in organic geochemistry 1985: Organic Geochemistry, v. 10, p. 17-27.

Schoell, M., 1983, Wasserstoff- and kohlenstoff isotopenvariationen in organischen substanzen, Erdölen und Erdgasen, Geologisches Jahrbuch, Reihe D, v. 67, 164 p.
1984, Recent advances in petroleum isotope geochemistry, in Schenck, P.A., DeLeeuw, J.W., and Lijmbach, G.W.M., eds. Advances in organic geochemistry 1983: Organic Geochemistry, v. 6, p. 645-663.

Silverman, S.R., and Epstein, S., 1958, Carbon isotopic composition of petroleums and other sedimentary organic materials: American Association of Petroleum Geologists Bulletin, v. 42, p. 998-1012.

Sofer, Z., 1984, Stable carbon isotope composition of crude oils: Application to source depositional environments and petroleum alteration: American Association of Petroleum Geologists Bulletin, v. 68, p. 31-49.

Tissot, B., and Welte, D., 1984, Petroleum formation and occurrence-A new approach to oil and gas exploration: Berlin, Springer-Verlag, 538 p.

Zumberge, J.E., 1987, Prediction of source rock characteristics based on terpane biomarkers in crude oils: A multivariate statistical approach: Geochimica et Cosmochimica Acta, v. 51, p. 1625-1637. 


\title{
Heavy Oil and Natural Bitumen
}

\author{
By Richard F. Meyer
}

Heavy crude oil and the natural bitumens are petroleum hydrocarbons distinguished from conventional crude oils by their high density and high viscosity. Because of these characteristics, their recovery from the reservoir and consequent transportation and refining is rendered difficult and costly. Most heavy oil requires the application of heat to be producible from a well. In the United States, two types of natural bitumen deposits are found, vein deposits and natural asphalt. Vein deposits, such as gilsonite, are rare and of little consequence as a source of liquid hydrocarbons. Most natural bitumens occur as natural asphalt (oil sands, tar sands) and are usually mined. In some places they can be produced by thermal enhancement; in mining, the bitumen must be physically separated from the mineral matrix and then upgraded to a liquid hydrocarbon before being processed at a refinery. Most deposits of heavy oil and natural bitumen are either gas free or have extremely low gasto-oil ratios.

Heavy oil and natural bitumen may be defined on several different bases: density and viscosity of the whole crude, percentage of whole crude that is a refinery residuum at approximately $540{ }^{\circ} \mathrm{C}\left(1,000{ }^{\circ} \mathrm{F}\right)$, or the ability to recover the crude oil by primary and secondary methods only. Using oil density and viscosity, the United Nations Information Centre for Heavy Crude and Tar Sands (Martinez, 1984) has set limits as follows: Hydrocarbons more viscous than $10,000 \mathrm{cp}$ are defined as bitumen, whereas those less viscous than $10,000 \mathrm{cp}$ are considered to be crude oil. Crude oil with a density range of $10^{\circ}-20^{\circ}$ API is defined as heavy oil. Extraheavy oil is more dense than $10^{\circ}$ API. Ordinarily, if an oil can be produced through a well and is less than $10^{\circ}$ API, it is assumed to be extra-heavy oil and not bitumen. A good example is the extra-heavy oil in the Venezuelan Orinoco Oil Belt. The API gravity of oil is the most commonly available physical attribute. Its viscosity is seldom reported. Heavy oil may also be distinguished (Oil and Gas Journal, 1983) on the basis of the proportion of residuum remaining when the whole crude is distilled to approximately $540{ }^{\circ} \mathrm{C}\left(1,000{ }^{\circ} \mathrm{F}\right)$. A residuum of 15 volume percent is commonly accepted as the criterion of a heavy oil even though the unrefined crude may have a high API gravity. Using this criterion, Brent crude from the North Sea is conventional, with a gravity of $38^{\circ}$ API and a residuum yield of only 10.3 percent. On the other hand, Ekofisk crude, also from the North Sea, might be called heavy conventional because it yields 25.2 percent residuum even though the whole crude gravity is $43.4^{\circ}$ API. A heavy crude oil such as Venezuelan Bachaquero $\left(16.8^{\circ} \mathrm{API}\right)$, yields 70.3 percent residuum. The California Oxnard natural bitumen has a gravity of $3.9^{\circ} \mathrm{API}$ and a residuum yield of 51 percent. Lastly, an upper limit to the density for heavy oil may be based on recoverability by primary and secondary methods (Chapman Cronquist, written commun., 1984), without resorting to enhanced (tertiary) recovery. Most heavy oil deposits are relatively free of gas. Waterflooding, a secondary method that may be used to enhance the original reservoir pressure, is only effective to about $18^{\circ} \mathrm{API}$. Thus, the upper limit for heavy oil needs to be set above $18^{\circ} \mathrm{API}$, and a gravity of $20^{\circ}$ API is the most widely accepted definitional limit even though it has no precise chemical basis.

The physical attributes of the heavy oils and natural bitumens are directly related to the chemical constituency, characterized by large molecules of asphaltenes and resins. In such organometallic complexes are found most of the nonhydrocarbon elements that make the heavy oils difficult to refine. With an increase in density to and beyond $20^{\circ}$ gravity API (Speight, 1980), the Conradson carbon greatly increases, the proportion of asphaltics increases notably, there is a decided increase in viscosity, and ordinarily the content of sulfur, oxygen, nitrogen, and such trace metals as nickel and vanadium rises significantly. Because these factors cause severe problems in recovery, transportation, and refining, they lead to a lower value for the crude. However, viscosity is notably sensitive to temperature, so that anything leading to higher reservoir temperature, such as high heat flow in the Earth or application of exogenous heat, simplifies recovery from the reservoir. After the heavy crude oil reaches the surface, the high-viscosity problem returns. There is no direct correlation between density and viscosity, except for each individual deposit. However, sufficiently accurate generalities may be drawn to permit use of density as a proxy for viscosity for most crudes, because of the general absence of any viscosity data.

The United States has four important areas of heavy oil production: California, 345 million barrels in 1986 in the Los Angeles, San Joaquin, Santa Maria, and Ventura basins; Rocky Mountains, 28 million barrels in 1986, in the Big Horn, Green River, and Powder River basins; Southwest, 40 million barrels in 1986, in the Arkla, East Texas, Gulf Coast, Mid-Gulf, and Permian 
basins; and the Alaskan North Slope, with no 1986 production. The three areas in the lower 48 United States yielded 413 million of the U.S. total of 423 million barrels. In terms of Original Reserves (proved reserves plus cumulative production), the same three areas contain 29.8 billion of a lower 48 States total of 30.5 billion barrels, with an additional 34.3-36.8 billion barrels on the North Slope. Of the 30.5 billion barrels, 18 percent is offshore; in depth, 10 percent is found at less than $150 \mathrm{~m}(500 \mathrm{ft}), 33$ percent between 150 and $600 \mathrm{~m}$ (500 and 2,000 ft), 45 percent between 600 and $1,500 \mathrm{~m}(2,000$ and $5,000 \mathrm{ft})$, and 12 percent below $1,500 \mathrm{~m}(5,000 \mathrm{ft}) ; 87$ percent is heavy oil, and 13 percent extra-heavy. Of the extra-heavy oil, 80.5 percent occurs at depths between 600 and $1,500 \mathrm{~m}(2,000$ and $5,000 \mathrm{ft}$ ), which suggests that much of this oil is immature rather than degraded light oil. About one-third of the heavy oil is located in giant fields (more than 500 million barrels of original reserves); these include South Belridge, Coalinga, Huntington Beach, Kern River, Midway-Sunset, San Ardo, and Wilmington in California and Hawkins and Smackover in the Southwest. When developed, the West Sak deposit on the North Slope will be a giant.

In the United States, most heavy oil is produced with the assistance of thermal enhancement recovery to reduce viscosity. Of 224 enhanced oil recovery (EOR) projects active in 1986, 182 utilized steam, 3 utilized hot water, and 17 utilized underground combustion (fireflood). The other 22 involved polymer, alkaline, and carbon dioxide floods. Overall, recovery of heavy oil in place averages about 28 percent but varies greatly; California recovery is about average.

The importance of understanding whether a heavy crude oil is an immature oil or a degraded conventional light oil is directly pertinent to oil recovery (Connan and Coustau, 1987). The entrapment of oil depends upon its buoyancy, the capillary pressures involved, and the hydrodynamics of the basin system. With a heavy oil, buoyancy is low, because an API gravity of $10^{\circ}$ equals a specific gravity of unity. Consequently, if its buoyancy is low, an oil will only saturate the most permeable zones in the reservoir, and these will be the ones preferentially swept by a steam drive. If a mature light oil is entrapped in a zone of low porosity and permeability, which might easily be the case, and subsequently degraded by bacteria and water washing, recovery will be very difficult because the steam will preferentially enter the zones of high permeability and porosity. If water washing increases, partially sweeping the reservoir, then recovery becomes nearly impossible, particularly when the reservoir rock itself is diagenetically altered by the water. A mature light oil degraded during migration will behave much like an immature oil, possessing low buoyancy and saturating only the most highly porous and permeable zones, where steam drive will be efficient. Before attempting enhanced recovery of heavy oil, therefore, it is exceedingly important to conduct studies of the porosity and permeability of the reservoir rock itself as well as of the oil, in order to predict recovery possibilities.

Of the natural bitumens, the asphaltites and asphaltic pyrobitumens (Abraham, 1960) are the least important quantitatively and economically but perhaps the most intriguing of the hydrocarbons scientifically. The asphaltites are asphalt-like, with fusing points greater than $110{ }^{\circ} \mathrm{C}$. The best known example is gilsonite, characterized by a specific gravity of 1.03 to 1.10 and fixed carbon content of 10-20 percent. Gilsonite occurs in a large vein in the Uinta basin, and its origin is still in question. A second variety is glance pitch, found in Emery County, Utah, with a specific gravity of 1.10 to 1.15 and a fixed carbon content of 20-35 percent. The third variety of asphaltite is grahamite, found in West Virginia, Oklahoma, and Colorado. It has a specific gravity of 1.15 to 7.20 and fixed carbon content of 35-55 percent.

The asphaltic pyrobitumens are infusible and have extremely low oxygen-to-carbon ratios. All are minor in occurrence and of little economic significance. Wurtzilite, found in Uintah County, Utah has a specific gravity of 1.05 to 1.07 and a fixed carbon content of 5-25 percent; albertite, in the same area, has a slightly higher specific gravity (1.07-1.10) and greater fixed carbon (25-50 percent); and impsonite, occurring in small veins in Oklahoma, Arkansas, Nevada, and Michigan, has a specific gravity of $1.10-1.25$ and fixed carbon content of 50-90 percent.

Natural asphalt is of far greater significance worldwide, both scientifically and economically. It is a natural bitumen that may occur in a relatively pure state, as in the pitch lake of Trinidad, or contained in clastic or carbonate reservoir rocks. The clastic reservoirs are commonly either sand or sandstone. Except for the Alberta Athabasca and related deposits, natural asphalts have historically been used solely as sources of road paving, mastic, and roofing material. These uses have largely been displaced by manufactured asphalt. Future use of large natural asphalt deposits will be mainly as a source of liquid hydrocarbons. At present, only the Alberta oil-sand bitumen is so used. It yields about 160,000 barrels per day of synthetic crude oil. In the United States, the original natural asphalt reserves are estimated to be about 43 billion barrels in the lower 48 States and 11 billion barrels on the North Slope of Alaska. The North Slope deposit, which occurs in the upper and lower parts of Ugnu sands, may be as large as 19 billion barrels. Most of the resources in the lower 48 States are contained in 11 deposits, each of which contains bitumen amounting to more than 1,000 million barrels. The two largest, each exceeding 6 billion 
barrels, are Northwest Alabama and Sunnyside, Utah. Others include Asphalt Ridge, Circle Cliffs, PR Spring, and Tar Sand Triangle, Utah, the Tri-State area of Missouri, Kansas, and Oklahoma, the San Miguel 'D' in Texas, the Big Clifty Sandstone in Kentucky, and Cat Canyon and the deposit of Foxen Sandstone, California.

Exploitation of natural asphalts for recovery of their included bitumen as a source of liquid hydrocarbons depends more upon economics than technology. With respect to mineability (Resnick and others, 1981), certain factors are fixed and others are flexible. The fixed factors include the structural characteristics of the ore body and surrounding strata; the geological characteristics of the deposit; topography; and location, areal extent, variability, and richness (grade) of the deposit. Factors allowing some flexibility are availability of water; transportation; labor and community infrastructures; and power resources. Finally, factors of environmental concern, socioeconomic status, the political environment, and ownership patterns may ultimately limit mining.

The Discounted Cash Flow Rate of Return (DCFROR) (Earley, 1987) is quite insensitive to the stripping ratio at shallow depths. However, the DCFROR is very sensitive to the richness (grade) of the deposit and to the size of the plant. In general, a grade of 8-10 weight percent bitumen is required with a plant size of at least 10,000 barrels per day. A smaller plant size implies a very rich, local ore source. Similarly, if the grade remains fixed, as net pay thickness diminishes, the area of the deposit must increase for a given plant size. Increased richness will lower the thickness/area requirement. Consequently, a resource equivalent to 250 million barrels of oil of $20^{\circ}$ API, covering 3,000 acres, would require thicknesses of about $13 \mathrm{~m}(42 \mathrm{ft})$ at grade of 11.6 weight percent, $18 \mathrm{~m}(58 \mathrm{ft})$ at 8.7 weight percent and $26 \mathrm{~m}(84 \mathrm{ft})$ at 5.8 weight percent (Herkenhoff, 1972).

Such data indicate that additional problems will be entailed in the transportation and upgrading of heavy oil and bitumen. These can most easily be visualized by equating the heavy oil and bitumen to the highest boiling temperature fraction of the refinery barrel, in which through the distillation process is concentrated most of the least desirable crude oil components: the large, complex molecules of hydrocarbons; the trace metals, nitrogen, and oxygen through organic complexes; and the sulfur.

The preceding review indicates that discrimination of the oil or bitumen in the various deposits with respect to their fundamental nature, whether immature or mature and degraded, is essential to an understanding of the petroleum systems to which the deposits belong. These data are also basic to an understanding of the most economical recovery methods to be employed. It is necessary, at the same time, to have a detailed knowledge of the reservoir rock itself, particularly the porosity and permeability characteristics. Research on the source beds which contributed hydrocarbons to the deposits will materially assist in understanding the nature of the occurrences.

With regard to the heavy oil fields, assumptions can be made as to the source and carrier beds in the same way as with conventional oil fields. To gain any degree of certainty, however, will require chemical analyses of the trapped oil and the oil in the assumed source beds. For bitumens, little attempt has been made to relate the deposits to source beds and avenues of migration. Because both the heavy oil fields and the bitumen deposits generally contain more or less severely degraded oils, positive identifications in order to assemble the petroleum system involved will require the attention of organic geochemists. Lack of understanding of the petroleum systems renders the location of new deposits and the effective exploitation of those already identified a very chancy business, one no longer acceptable in its inefficiency.

\section{REFERENCES CITED}

Abraham, Herbert, 1960, Asphalts and allied substances, 6th ed.: New York, Van Nostrand, v. 1,370 p.

Connan, J.M., and Coustau, Henri, 1987, Influence of the geological and geochemical characteristics of heavy oils on their recovery, in Meyer, R.F., ed., Exploration for heavy crude oil and natural bitumen: American Association of Petroleum Geologists Studies in Geology 25, p. 261-280.

Earley, J.W., 1987, Economic factors in near-surface heavy-oil/tar sand mining, in Meyer, R.F., ed., Exploration for heavy crude oil and natural bitumen: American Association of Petroleum Geologists Studies in Geology 25, p. 669-671.

Herkenhoff, E.C., 1972, When are we going to mine oil?: Engineering and Mining Journal, v. 173, no. 6, p. 132-138.

Martinez, A.R., 1984, Report of working group on definitions, in Meyer, R.F., Wynn, J.C., and Olson, J.C., The future of heavy crude and tar sands: New York, McGraw-Hill, p. xvii-xviii.

Oil and Gas Journal, 1983, U.S. crude oil imports shift to heavier category: v. 81 , no. 25 , p. 78 .

Resnick, B.S., Dike, D.H., English, L.M., III, and Lewis, A.G., 1981, Evaluation of tar sand mining; v. 1. An assessment of resources amenable to mine production: U.S. Department of Energy DOE/ET/30201-1 (DE82010249), 214 p.

Speight, J.G., 1980, The chemistry and technology of petroleum: New York, Marcel Dekker, 498 p. 


\title{
Geochemical Correlations in Petroleum Systems
}

\author{
By Donald E. Anders
}

Hydrocarbons in conventional petroleum and gas accumulations (nonbacterial) are degradation products of macromolecular organic structures (known as kerogen) disseminated in fine-grained sedimentary rocks. Kerogen breakdown occurs by a succession of physical and chemical transformations (diagenesis, catagenesis, and metagenesis) in response to burial heating over geologic time. The kerogen structures and the type of hydrocarbons (gas and liquid) produced from them during thermal evolution are related to the principal sources of the organic matter (algal, microbial, higher plants, and so on) and chemical conditions during deposition of the organic matter.

The existence and recognition of distinct physical and chemical similarities between hydrocarbons in a reservoir and the insoluble (kerogen) and soluble (bitumen) organic constituents still retained in the source rock is the basis for geochemical correlation. Conversely, establishing that pairs of oils or oil-source rocks are not genetically related is based on the supposition that unrelated samples have geochemical dissimilarities. The ability to establish oil-to-oil, oil-tosource, gas-to-gas, gas-to-oil and gas-to-source genetic relationships are based on the assumption that the processes acting on the separated hydrocarbons, such as migration, thermal maturation, biodegradation, and water washing, do not adversely affect all of the composition parameters necessary for correlation.

Before geochemical correlations are performed, the petroleum geologist needs to make sure that the combined geologic setting of the pooled hydrocarbons, proposed migrational pathways, and presumed source rocks are in harmony with the stratigraphic, structural, tectonic, and hydrodynamic constraints within the basin. Once the geologic setting has been worked out, geochemistry can establish the resource potential of probable source rocks, and correlation studies can determine the number of genetically related (families) oils, gases, and condensates in the basin and in identifying the source rocks from which the pooled hydrocarbons are derived. Correlation studies are also helpful in establishing possible communication between different pay zones (producing horizons) and fault blocks (Tissot and Welte, 1984, p. 549).

Two kinds of chemical properties are used for correlation purposes: (1) bulk parameters which describe properties of the whole sample; and (2) specific parameters which measure in detail the chemical characteristics of a fraction of the sample. The most commonly employed correlation parameters in use today are listed in table 11.

The choice of compositional parameter for correlation depends upon the type of hydrocarbon deposit to be correlated (gas, oil, condensate, biodegraded heavy oil, or tar sand) and the availability of methods to the explorationist. In conventional oil-to-oil and oil-tosource rock correlation studies, a large number of parameters can be used (see table 11 and Koons and others, 1974; Williams, 1974; Seifert and Moldowan, 1978; Seifert and others, 1980; Welte and others, 1975, 1982; Poole and Claypool, 1984) In other cases, such as the correlation of gases to one another or to oils or to their source rocks, only a limited number of parameters are useful: $\mathrm{C}_{1} / \mathrm{C}_{1}-\mathrm{C}_{4}$ (wetness), $\mathrm{C}_{5}-\mathrm{C}_{7}$ hydrocarbon distribution, and $\delta^{13} \mathrm{C}$ and $\delta \mathrm{D}$ (Schoell, 1981, 1983, 1984). In overmature rocks and oils or in biodegraded heavy oil seeps and tar sands, the choice of correlation parameters is again limited: naphthenoaromatics, aromatics, thiophenes, polycyclic naphthenes, and $\delta^{13} \mathrm{C}$ (Tissot and others, 1974; Rullkötter and Welte, 1980; Moldowan and Seifert, 1980, Claret and others, 1977; Palacas and others, 1986; Anders and Magoon, 1986). A problem sometimes encountered in oil-to-source rock correlation is the occurrence of migrated hydrocarbons in the presumed source rock. A relatively new technique of pyrolyzing the kerogen or asphaltenes in the rock and then comparing the hydrocarbons of the pyrolyzate with the hydrocarbons in the oil has been extremely helpful in this regard (Rubinstein and others, 1979; Behar and others, 1984; Durand, 1983; Lewan and others, 1979).

One of the most useful tools for correlations that has been developed in the past 20 years is in the area of high-resolution gas chromatography-mass spectrometry. This technique allows the fingerprinting of any number of classes of chemical compounds in the oil and bitumen or pyrolyzate for direct comparison. The compound types most useful for correlation, because of their ubiquitous nature and their stability over a wide range of geologic conditions, are the polycyclic naphthenes and naphthenoaromatics. These compounds, often referred to as "geochemical fossils" or "biological markers," are so called because they often retain enough of their original chemical character and skeletal structure so as to be able to relate them unambiguously to known biochemical molecules in living organisms (Anderson and others, 1969; Hills and others, 1966; Anders, 1970; Kimble and 
Table 11. The most commonly used correlation parameters and their general application in gas-oil-source studies

[y, application used; $\mathbf{n}$, application not used; -, poor or not useful; +, sometimes useful; ++, often useful; +++, very useful; parameters can be affected by: 1 , migration; 2 , maturation; 3 , biodgradation; *, useful in comparing very mature and degraded oils; $\mathrm{C}$, carbon; $\mathrm{D}$, deuterium; $\mathrm{N}$, nitrogen; Ni, nickel; $O$, oxygen; $S$, sulfur; $V$, vanadium; $C_{\#}$, number of carbon atoms per molecule]

\begin{tabular}{|c|c|c|c|c|c|c|c|c|}
\hline \multicolumn{3}{|l|}{$\begin{array}{ll}\text { Analyses }\end{array}$} & \multicolumn{5}{|c|}{ Application } & \multirow{2}{*}{ Comments } \\
\hline Description & Bulk & Specific & Oil-oil & Oil-source & Gas-gas & Gas-oil & Gas-source & \\
\hline \multicolumn{9}{|l|}{$\overline{\delta^{13} \mathrm{C}}$} \\
\hline Kerogen & $\mathbf{y}$ & $\mathrm{y}$ & +++ & +++ & - & - & - & 2 \\
\hline Bitumen & $\mathbf{y}$ & $\mathrm{y}$ & t+t & +++ & - & - & - & $1,2,3$ \\
\hline Crude oil & $\mathrm{y}$ & $\mathrm{y}$ & +++ & +++ & - & - & - & $1,2,3$ \\
\hline Saturated hydrocarbons & $\mathrm{y}$ & $\mathrm{y}$ & t++ & +++ & - & - & - & $1,2,3$ \\
\hline Aromatic hydrocarbons & $\mathrm{y}$ & $\mathrm{y}$ & +++ & +++ & - & - & - & 1,2 \\
\hline NSO nonhydrocarbons & $\mathrm{y}$ & $\mathrm{y}$ & +++ & +++ & - & - & - & 1,2 \\
\hline Asphaltenes & $\mathrm{y}$ & $\mathrm{y}$ & t+t & t++ & - & - & - & 1,2 \\
\hline Methane gas & $\mathrm{n}$ & $\mathrm{y}$ & - & - & +++ & +++ & t++ & \\
\hline Ethane gas & $\mathrm{n}$ & $\mathrm{y}$ & - & - & +++ & +++ & +++ & \\
\hline \multicolumn{9}{|l|}{$\delta \mathrm{D}$} \\
\hline Methane gas & $\mathbf{y}$ & $\mathrm{n}$ & t++ & +++ & +++ & t+t & t++ & \\
\hline \multicolumn{9}{|l|}{$\delta^{34} \mathrm{~S}$} \\
\hline Crude oil & $\mathbf{y}$ & $\mathrm{n}$ & +++ & +++ & - & - & - & \\
\hline Bitumen & $\mathbf{y}$ & $\mathrm{n}$ & t++ & +++ & - & - & - & \\
\hline \multicolumn{9}{|l|}{ Ratios of: } \\
\hline Saturated-/aromatic hydrocarbons & $\mathrm{y}$ & $\mathrm{n}$ & t++ & + & - & - & - & $1,2,3$ \\
\hline Hydrocarbons/nonhydrocarbons & $\mathrm{y}$ & $\mathrm{n}$ & +++ & + & - & - & - & $1,2,3$ \\
\hline \multicolumn{9}{|l|}{ Molecular distribution of: } \\
\hline $\mathrm{C}_{1} / \Sigma \mathrm{C}_{1}-\mathrm{C}_{4}$ (wetness) & $\mathbf{n}$ & $\mathbf{y}$ & - & - & ++ & - & - & \\
\hline $\mathrm{C}_{5}-\mathrm{C}_{7}$ & $\mathbf{n}$ & $\mathrm{y}$ & +++ & - & + & + & - & 3 \\
\hline$n$-paraffins & $\mathrm{n}$ & $\mathbf{y}$ & +++ & ++t & - & - & - & 3 \\
\hline Naphthenes & $\mathbf{n}$ & y & +++ & +++ & - & - & - & \\
\hline Aromatics* & $\mathbf{n}$ & y & ++ & ++ & - & - & - & \\
\hline Thiophenes" & $\mathrm{n}$ & $y$ & + & + & - & - & - & \\
\hline Isoprenoids & $\mathbf{n}$ & $\mathrm{y}$ & +++ & +++ & - & - & - & \\
\hline Diterpenoids & $\mathbf{n}$ & $\mathrm{y}$ & t++ & +++ & - & - & - & \\
\hline Triterpenoids & $\mathrm{n}$ & $\mathbf{y}$ & t+ & ++ & - & - & - & $1,2,3$ \\
\hline Steranes & $\mathbf{n}$ & y & t+ & t+ & - & - & - & $1,2,3$ \\
\hline Aromatic steroids" & $\mathrm{n}$ & y & ++ & ++ & - & - & - & 2 \\
\hline Porphyrins & n & $y$ & ++ & + & - & - & - & 2 \\
\hline API gravity & $\mathbf{y}$ & $\mathrm{n}$ & ++ & - & - & - & - & 3 \\
\hline $\mathrm{V} / \mathrm{Ni}$ ratio & $\mathrm{n}$ & $\mathbf{y}$ & t+t & ++ & - & - & - & 1 \\
\hline Percent $S$ & $\mathrm{y}$ & $\mathrm{n}$ & +++ & +++ & - & - & - & 1,2 \\
\hline Percent N & $\mathrm{y}$ & $\mathbf{n}$ & t+t & +++ & - & - & - & 1,2 \\
\hline Optical activity & $\mathrm{y}$ & $\mathrm{n}$ & ++ & + & - & - & - & 2,3 \\
\hline Infrared spectra & $\mathrm{y}$ & $\mathrm{n}$ & ++ & +t & - & - & - & \\
\hline Hydrous pyrolysis on kerogen & $\mathrm{y}$ & $\mathrm{n}$ & - & +t & - & - & - & \\
\hline Hydrous pyrolysis on asphaltenes & $\mathrm{y}$ & $\mathrm{n}$ & - & ++ & - & . & - & \\
\hline
\end{tabular}

others, 1974). If enough molecular information is retained on the "chemical fossil," it is possible to interpret the biological processes leading to its formation and perhaps even infer something about the chemical conditions during deposition and specific types of chemical reactions that occurred (for example: oxic, euxinic, thermal, hydrolyzing, decarboxylating) between the time of the organism's death and its discovery eons later.

Although many biomarker hydrocarbons such as acyclic isoprenoids, steranes, and tri- and pentacyclic terpanes are ubiquitous in sedimentary organic matter and petroleum resources, their relative distributions are not. Of particular value in correlation studies are 
biomarker compounds which occur in a limited number of organisms. For comprehensive literature reviews on the use of biomarkers for correlation, see Connan (1981), Philp (1982), MacKenzie (1984), Tissot and Welte (1984), Waples (1985), and Johns (1986).

When making correlation studies, as many different parameters should be used as economically feasible because from a chemical standpoint, it is far easier to prove that unrelated samples are different than it is to prove that similar samples are genetically related. The best correlations are those where both bulk and specific chemical properties are in agreement with one another and with the geologic constraints placed on the samples being compared.

An example of a correlation study done in the Uinta basin of Utah to answer one of the questions frequently asked by petroleum explorationists (are the tar sand oils and gilsonite deposits derived from shallow immature, marginally mature, or deep mature sources?) is shown in figure 8 and table 12. In this example, both bulk properties and specific biomarker traces $(\mathrm{m} / \mathrm{z} 217=$ steranes, $m / z 191=$ tri- and pentacyclic terpanes, and $m / z$ 231 and 253 = tri- and monoaromatic steroids) are used for correlation. The degree of similarity in the bulk properties (carbon and sulfur isotopes) and biomarker distributions for all of the samples except the deepest oil suggests that the gilsonite, tar sand, and shallowest oil are all derived from the bitumen extracted from the organic matter in the Green River Formation. This proposed relationship is in agreement with geologic evidence as the accumulations are in stratigraphic communication with the source. The level of thermal maturity for various hydrocarbon compounds (based on certain isomeric and molecular ratios) in this comparison study also suggests that all of the hydrocarbons but the deepest oil are derived from rocks at similar levels of thermal stress (vitrinite reflectance equivalence $=0.4$ to 0.6 percent $R_{o}$ ). This is further supported by vitrinite reflectance measurements: reservoir rocks of the 2,750 $\mathrm{m}(9,000 \mathrm{ft})$ oil have a $\mathrm{R}_{\mathrm{o}}=0.8$ percent whereas the reservoir rocks of the $1,435 \mathrm{~m}(4,700 \mathrm{ft})$ oil and the rocks from which the bitumen was extracted have $a R_{0}=$ 0.5 percent. The geochemical and geologic evidence strongly suggests that the gilsonite and tar sand are derived from immature to marginally mature organic matter in rocks of the Green River Formation.

\section{REFERENCES CITED}

Anders, D.E., 1970, Cycloalkanes from Green River oil shale and their relationship to living organisms: Laramie, University of Wyoming, M.S. Thesis, $36 \mathrm{p}$.

Anders, D.E., and Magoon, L.B., 1986, Oil-source correlation study in northeastern Alaska, in
Rullkötter, J., and Leythaeuser, D., eds., Advances in organic geochemistry 1985: Organic Geochemistry, v. 10, p. 407-415.

Anderson, P.C., Gardner, P.M., Whitehead, E.V., Anders, D.E., and Robinson, W.E., 1969, The isolation of steranes from Green River oil shale: Geochimica et Cosmochimica Acta, v. 33, p. 1304-1307.

Behar, F., Pelet, R., and Roucache, J., 1984, Geochemistry of asphaltenes, in Schenk, P.A., ed., Advances in organic geochemistry 1983: Organic Geochemistry, v. 6, p. 587-595.

Claret, J., Tchikaya, J.B., Tissot, B., Deroo, G., and vanDorsselaer, A., 1977, Un exemple d'huile biodegradée a basse teneur en soufre: le gisement d'Emeraude (Congo), in Campos, R., and Goni, J., eds., Advances in organic geochemistry 1975: Madrid, ENADIMSA, p. 509-522 (in French).

Connan, J., 1981, Biological markers in crude oils, in Mason, J.F., ed., Petroleum geology in China 1980: Tulsa, Penn Well, p. 48-70.

Durand, B., 1983, Present trends in organic geochemistry in research on migration of hydrocarbons, in Bjoroy, M., ed., Advances in organic geochemistry 1981: Chichester, Wiley, $p$. 117-128.

Hills, I.R., Whitehead, E.V., Anders, D.E., Cummings, J.J., and Robinson, W.E., 1966, An optically active triterpane, gammacerane in Green River oil-shale bitumen: Chemical Communications, v. 20 , p. $752-754$.

Johns, R.B., 1986, Biological markers in the sedimentary record: Amsterdam, Elsevier, 364 p.

Kimble, B.J., Maxwell, J.R., Philip, R.P., and Eglinton, G., 1974, Identification of steranes and triterpanes in geolipid extracts by highresolution gas chromatography and mass spectrometry: Chemical Geology, v. 14, p. 173-198.

Koons, C.B., Bond, J.G., and Peirce, F.L., 1974, Effects of depositional environment and postdepositional history on chemical composition of lower Tuscaloosa oils: American Association of Petroleum Geologists Bulletin, v. 58, p. 1272-1280.

Lewan, M.D., Winters, J.C., and MacDonald, J.H., 1979, Generation of oil-like pyrolyzates from organicrich shales: Science, v. 203, p. 897-899.

MacKenzie, A.S., 1984, Application of biological markers in petrogeochemistry, in Brooks, J., and Welte, D., eds., Advances in petroleum geochemistry, v. 1: London, Academic Press, p. 115-214.

Moldowan, J.M., and Seifert, W.K., 1980, First discovery of botryococane in petroleum: Journal of the 

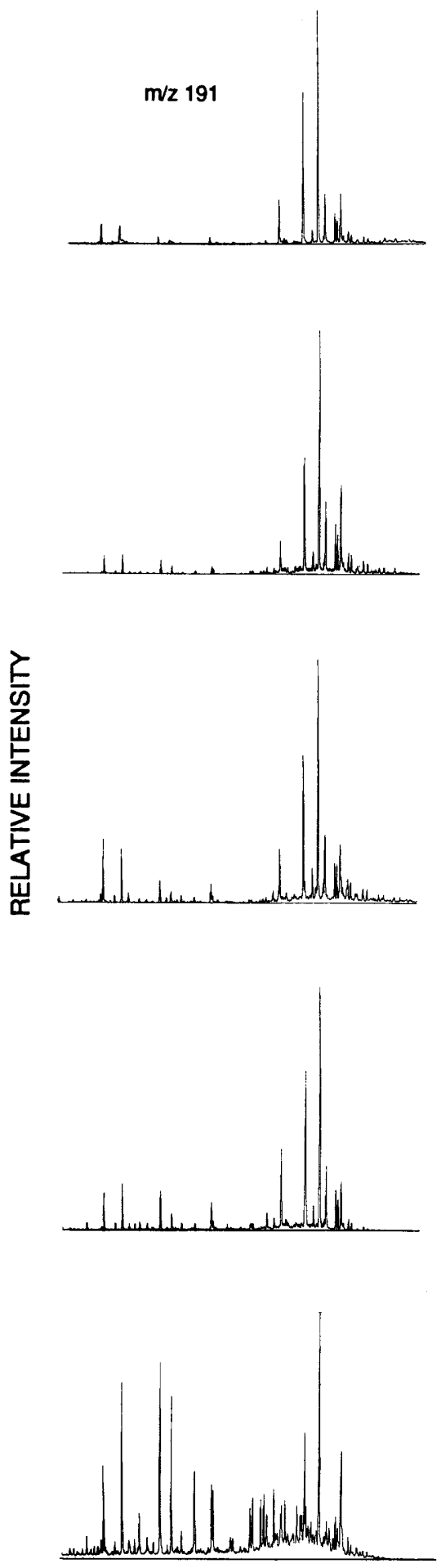

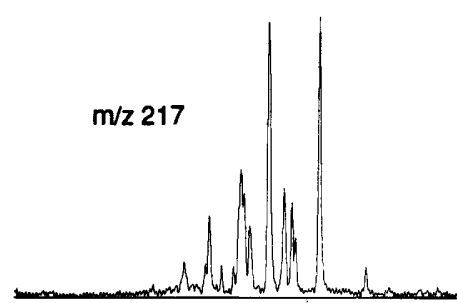

Eureka gilsonite (surface)

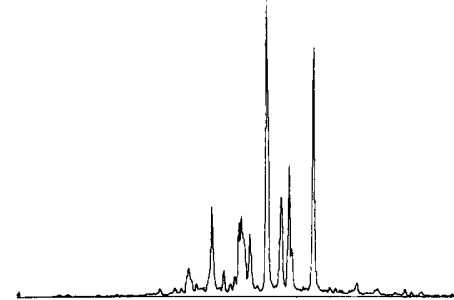

Asphalt Ridge tar sand (surface)
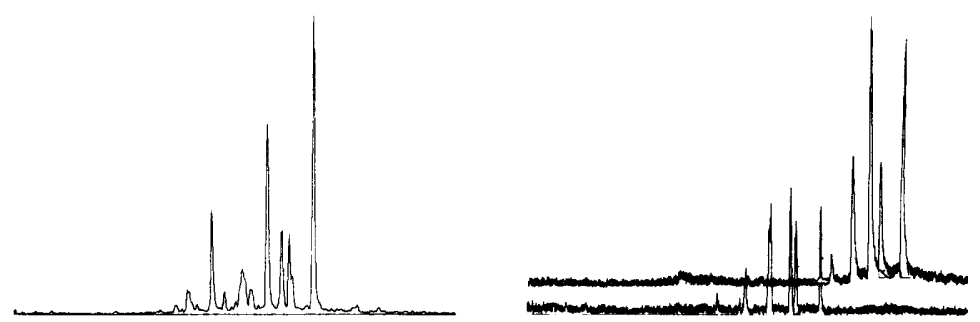

Parachute Creek bitumen (2480 ft)
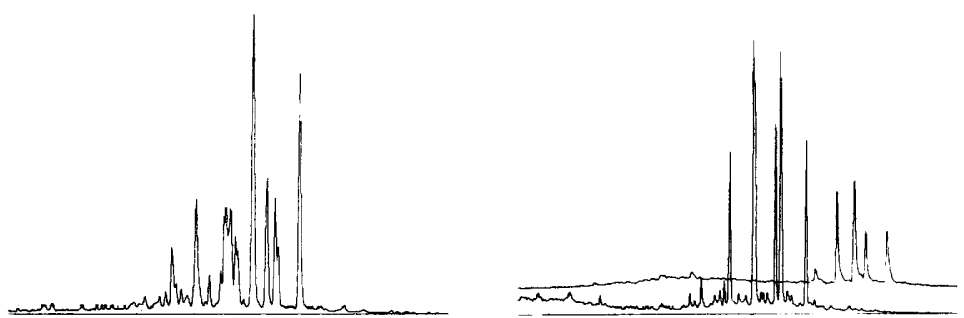

Red Wash oil (4042-4082 ft)
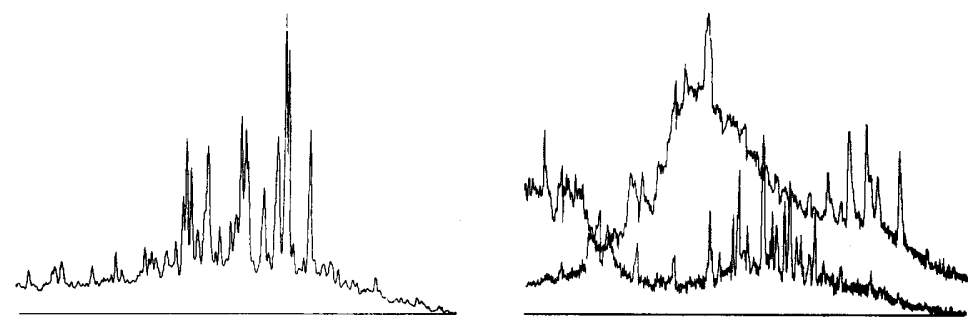

Bluebell oil (9230-9898 ft)

TIME $\rightarrow$

Figure 8. Comparison of biomarker distributions in these gas chromatograms show that gilsonite and tar sand oil at the surface are related to immature, shallow bitumen $(756 \mathrm{~m} ; 2,480 \mathrm{ft})$ or oil $(1,397 \mathrm{~m} ; 4,682 \mathrm{ft})$ rather than to the deep mature oil $(2,743 \mathrm{~m} ; 9,000 \mathrm{ft})$. Data are summarized in table 12 . 
Table 12. Some commonly used correlation parameters to show the origin of gilsonite and tar sand oil

\begin{tabular}{|c|c|c|c|c|c|}
\hline \multirow[t]{2}{*}{ Sample name } & \multicolumn{2}{|c|}{ Burial depth } & \multirow{2}{*}{$\begin{array}{c}\delta^{34} S \\
\text { Elemental } \\
\text { sulfur }\end{array}$} & \multicolumn{2}{|c|}{$\delta^{13} \mathrm{C}$} \\
\hline & $\mathrm{m}$ & $\mathrm{ft}$ & & $\begin{array}{c}\text { Saturated } \\
\text { hydrocarbons }\end{array}$ & $\begin{array}{c}\text { Aromatic } \\
\text { hydrocarbons }\end{array}$ \\
\hline Eureka Gilsonite & Surface & Surface & +27.9 & -32.7 & -31.8 \\
\hline Asphalt Ridge tar sand & Surface & Surface & +30.0 & -31.9 & -30.7 \\
\hline Parachute Creek bitumen & 756 & 2,480 & +30.8 & -32.2 & -31.8 \\
\hline Red Wash oil & 1,397 & 4,682 & +28.4 & -32.2 & -31.2 \\
\hline Bluebell oil & 2,743 & 9,000 & +16.6 & -31.6 & -30.4 \\
\hline
\end{tabular}

Chemical Society Chemical Communications, v. 34, p. 912-914.

Palacas, J.G., Monopolis, D., Nocolaou, C.A., and Anders, D.E., 1986, Geochemical correlation of surface and subsurface oils, western Greece, in Rullkötter, J., and Leythaeuser, D., eds., Advances in organic geochemistry 1985: Organic Geochemistry, v. 10, p. 417-423.

Philp, R.P., 1982, Application of computerized gas chromatography-mass spectrometry to fossil fuel research: Spectra, v. 8, p. 6-31.

Poole, F.G., and Claypool, G.E., 1984, Petroleum source-rock potential and crude-oil correlation in the Great Basin, in Woodward, J., Meissner, F.F., and Clayton, J.L., eds., Hydrocarbon source rocks of the greater Rocky Mountain Region: Denver, Rocky Mountain Association of Geologists, p. 179-229.

Rubinstein, I., Spyckerelle, C., and Strausz, O.P., 1979, Pyrolysis of asphaltenes: A source of geochemical information: Geochimica et Cosmochimica Acta, v. 43, p. 1-6.

Rullkötter, J., and Welte, D.H., 1980, Oil-oil and oilcondensate correlation by low eV GC-MS measurements of aromatic hydrocarbons, in Douglas, A.G., and Maxwell, J.R., eds., Advances in organic geochemistry 1979: Oxford, Pergamon Press, p. 93-102.

Schoell, M., 1981, Application of isotopic analyses in oil and natural-gas research: Erdöl und Kohle, Erdgas, Petrochemie, v. 34 , p. 537-544 (in German).

1983, Genetic characterization of natural gases: American Association of Petroleum Geologists Bulletin, v. 67, p. 2225-2238.

1984 , Stable isotopes in petroleum research, in
Brooks, J., and Welte, D.H., eds., Advances in petroleum geochemistry v. 1: London, Academic Press, p. 215-245.

Seifert, W.K., and Moldowan, J.M., 1978, Application of steranes, terpanes and monoaromatics to the maturation, migration and source of crude oils: Geochimica et Cosmochimica Acta, v. 42, p. 77-95.

Seifert, W.K., Moldowan, J.M., and Jones, R.W., 1980, Application of biological marker chemistry to petroleum exploration: 10th World Petroleum Congress Proceedings, v. 2, p. 425-438.

Tissot, B.P., Durand, B., Espitalii, J., and Combaz, A., 1974, Influence of nature and diagenesis of organic matter in formation of petroleum: American Association of Petroleum Geologists Bulletin, v. 58, p. 499-506.

Tissot, B.P., and Welte, D.H., 1984, Petroleum formation and occurrence: Berlin, Springer-Verlag, 699 p.

Waples, D.W., 1985, Geochemistry in petroleum exploration: Boston, International Human Resources Development Corporation, $232 \mathrm{p}$.

Welte, D.H., Hagemann, H.W., Hollerbach, A., Leythaeuser, D., and Stahl, W., 1975, Correlation between petroleum and source rock: 9th World Petroleum Congress Proceedings, v. 2, p. 179-191.

Welte, D.H., Kratochvil, H., Rullkötter, J., Ladwein, H., and Schaefer, R.G., 1982, Organic geochemistry of crude oils from the Vienna Basin and an assessment of their origin: Chemcal Geology, $v$. 35 , p. 33-68.

Williams, J.A., 1974, Characterization of oil types in Williston Basin: American Association of Petroleum Geolgoists Bulletin, v. 58, p. 1243-1252. 


\title{
Computer Applications
}

\author{
By Kenneth I. Takahashi, Thaddeus S. Dyman, and Leslie B. Magoon
}

\section{INTRODUCTION}

The Branch of Petroleum Geology conducts topical and regional research on geological, geochemical, and geophysical aspects on the origin, migration, accumulation, and distribution of petroleum resources. Computerized information and data systems are accessed continually during these research activities. In addition, data generated within the branch as part of the research effort are integrated with existing data systems and computer software. The computerized data acquired through this research are valuable for defining, illustrating, and describing a petroleum system.

The purpose of this paper is to describe (1) the computer and data systems available to the Branch of Petroleum Geology and (2) how these data systems can be integrated to facilitate petroleum system research.

\section{COMPUTER APPLICATIONS}

Computer support for the petroleum system research includes computer programming, data bases and data management, and applications software. Computer programming support includes writing new computer programs or modifying existing programs for research applications. Data systems support includes accessing available data bases, developing new data bases, and integrating data from computerized files using data management software. Existing computer software applications include spread sheets, word processing, statistical and numerical analyses, data summary and tabulation, and mapping and contouring. Computer systems support includes dissemination of geological information for all phases of petroleum system research.

\section{Computer Systems}

In Denver, Colorado, the Branch of Petroleum Geology facilities include a $200-\mathrm{m}^{2}\left(2,200 \mathrm{ft}^{2}\right)$ computer room and two user rooms with terminals and plotters accessable to the user. A VAX $11 / 780$ is used by the geologic research staff and includes considerable software; a MicroVAX is used for word-processing. For geophysical processing, a DISCO VAX 11/780 system is in a separate computer room. In Menlo Park, California, a VAX $11 / 750$ is used by the research staff and has the same software that is available in Denver. Table 13 lists the computer systems and software packages.

In Denver, a MicroVAX II is used for word- processing; WPS-plus software is used by clerical and geologic staff and can be accessed from terminals in offices, in the centrally located user rooms, or by dialup telephones from remote facilities. Printers are located in several easily accessible locations. Using WPS-plus, documents can be exchanged between technical and clerical staff for editing and review and transmitted to other U.S. Geological Survey offices. The DISCO VAX $11 / 780$ is located in a separate facility maintained by the Geophysics research group. This system is used mainly for seismic data processing and reprocessing and seismic interpretation. Several computers dedicated to petroleum geochemical and well log analysis are also available to research scientists. In addition, personal computers and Macintoshs are being used for graphics, desk-top publishing, and statistical analyses.

Communications and networking options on branch computers are flexible. The VAX systems can be accessed from throughout the United States using the wide-area networks Geonet and Tymenet, maintained by the U.S. Geological Survey. Interactive user sessions and file transfers are possible within the network. The VAX 11/780, Microvax II, and the DISCO VAX are also linked together locally using DECnet, allowing users on any of our systems to transfer files, messages, or documents to other users on any other VAX system linked to either the local or wide-area networks.

\section{Data Management}

The Branch of Petroleum Geology uses TECH/SYS and Datatrieve for storage and retrieval of large data files on the VAX 11/780. TECH/SYS, a file management and data retrieval system designed by Petroleum Information Corporation (PI) of Denver, Colorado, uses a command file of data and format specifications to retrieve data from up to four data bases at one time (Petroleum Information Corporation, 1984). TECH/SYS was originally designed to retrieve wellhistory data from PI's Well History Control System (WHCS); it is also used to access the Petroleum Data System (PDS), the NRG Associates Significant Oil and Gas Fields File for field and reservoir data, and the North Slope geochemistry file. TECH/SYS will also be used to retrieve data from the Petroleum System Data Base (PSDB), where data will be stored by individual petroleum systems.

Datatrieve is a database program developed by Digital Equipment Corporation which has data base 
updating and file management capabilities that are tied to the VAX VMS operating system. Datatrieve is used to retrieve bibliographic data and data from small project files developed for petroleum system applications.

\section{Applications Software}

Applications software includes programs for digital mapping, statistical and numerical analyses, and graphical data display. Most digital maps are produced using Dynamic Graphics Corporation's Interactive Surface Modeling (ISM) system. Special ISM features are menu-driven parameter selection, file management, graphic editing, zooming and panning of graphic data, and grid and data manipulation (Dynamic Graphics Corporation, 1986). ISM is used with the Well History Control System (WHCS) data to produce isopach, structure, and total-sediment thickness maps. Petrologic, geochemical, and geophysical data can also be mapped.

The Geologic Analysis System (GAS) was developed by PI and contains computer software for graphic display and statistical analyses of geologic and lithologic data. GAS includes TECH/SYS, discussed above; Petroleum Information Contouring System (PICS); Petroleum Geochemical System (PGS); TimeTemperature Index (TTI); Stratigraphic Report Graphic (SRG); and Sample Data System (SDS).

PICS is a general-purpose contouring software package that can post wells from the WHCS file. Each posted well symbol can be annotated with up to four values; any one well can be represented by up to ten status symbols. For most uses, this software package has been supplanted by ISM.

PGS includes data files and applications programs for commonly available petroleum geochemical analyses. The analyses are of the type that an exploration geologist would use to evaluate the richness, organic type, and thermal history of important sourcerock intervals from the perspective of the drilling well or the entire basin. Data files include geochemistry, WHCS, wireline logs, lithology, and temperature.

TTI is a burial history software package based on the Lopatin method of Waples $(1980,1981)$. Burial history profiles, past and present temperature gradients, and indicators of thermal history are used in concert to calculate the time-temperature indices, which are then mapped to show hydrocarbon generating zones throughout geologic time.

SRG is a stratigraphic applications program that accepts sedimentologic, paleontologic, lithologic, paleoecologic, and nomenclatural data for outcrop sections and cores, and displays these data in a scalevariant format (Petroleum Information Corporation, 1984; Dyman and others, 1985).

SDS is a statistical and graphic module that includes correspondence, factor, and cluster analysis; the graphic module generates triangular and cross plots
(Petroleum Information Corporation, 1984).

Additional software includes the Statistical Package for the Social Sciences (SPSS), Minitab, and TELL-A-GRAF. Resource assessment computer programs such as FASP have also been developed by the Branch. FASP is a fast appraisal system for petroleum play analysis using a reservoir-engineering geologic model and an analytic probabilistic methodology (Crovelli and Balay, 1986).

\section{Data Systems}

The Branch of Petroleum Geology accesses PI's Well History Control System (WHCS), the Petroleum Data System (PDS), the NRG Associates Significant Oil and Gas Field File (NRG), and the Petroleum Geochemistry file (PGF)(table 13).

WHCS contains information on geologic, engineering, production, and formation tests, and descriptive location for more than 1.7 million wells drilled in the United States. Parts of the WHCS data base are stored either online on disk or offline on magnetic tape depending on the level and variety of usage within the branch. A WHCS extract file containing basic location, completion, and identification information for all wells in the WHCS file is available using Datatrieve. This file is used for a variety of basin analysis and resource assessment applications.

PDS is a historical file containing geologic, engineering, and production data for more than 80,000 oil and gas fields and reservoirs in the United States (Dyman, 1978). PDS annual production figures are presently acquired from PI, but no system is presently available to update geologic data for existing fields and reservoirs.

The NRG Associates Significant Oil and Gas Fields File (NRG) is similar to PDS but only includes data for fields with ultimate recoverable resources larger than 1 million barrels (NRG Associates, 1985). This file also contains reserve data and is updated annually.

A petroleum geochemistry data base (PGF) is now being developed. Data will include standard organic geochemical analyses such as vitrinite reflectance, pyrolysis, thermal alteration index (TAI), total organic carbon (TOC), and chromatographic data. This data base expands on the Alaska North Slope geochemistry file, and will include both new and historic data from the branch's organic geochemical laboratory.

\section{PETROLEUM SYSTEM DATA BASE (PSDB)}

In order to quantitatively define and analyze a petroleum system, a Petroleum System Data Base (PSDB) is now being developed by the Branch of Petroleum Geology. Table 14 contains the preliminary file structure for the PSDB. Data from the PSDB can be 
Table 13. Computer systems specifications and software, Branch of Petroleum Geology

[SPSS, Statistical Package for the Social Sciences; ISM, Interactive Surface Modeling; RGSL, Regional Geophysical software library; GAS, Geologic analysis system which includes TECH/SYS (Petroleum Information data base management system, now called PI Base), PICS (Petroleum Information contouring system), PGS (Petroleum geochemical system), TTI (Time-temperature index), SRG (Stratigraphic report graphic), and SDS (Sample data system); WHCS, Well history control system; PDS, Petroleum data system; NRG, NRG Associates oil and gas field file; PGF, Petroleum geochemical file; PC, Personal computer]

\begin{tabular}{|c|c|c|c|}
\hline System & Location & Hardware specifications & Software packages \\
\hline VAX $11 / 780$ & Denver & $\begin{array}{l}8 \text { megabytes memory, } \\
7 \text { gigabytes disk storage; } \\
\text { color graphics terminals; } \\
\text { plotters, digitizers; } \\
\text { VMS operating system; } \\
\text { DECNet communications }\end{array}$ & $\begin{array}{l}\text { Data and applications software: } \\
\text { Minitab, SPSS, ISM, RGSL, GAS } \\
\text { WHCS, PDS, NRG, PGF }\end{array}$ \\
\hline MicroVAX II & Denver & $\begin{array}{l}16 \text { megabytes memory; } \\
456 \text { megabytes disk storage } \\
\text { laser text printers; } \\
\text { DECNet communications }\end{array}$ & WPS-plus \\
\hline VAX $11 / 780$ & Denver & $\begin{array}{l}24 \text { megabytes memory; } \\
1.2 \text { gigabytes disk storage; } \\
\text { VMS operating system }\end{array}$ & $\begin{array}{c}\text { DISCO seismic processing; } \\
\text { Explorer }\end{array}$ \\
\hline VAX $11 / 750$ & Menlo Park & $\begin{array}{l}4 \text { megabytes memory; } \\
1.1 \text { gigabytes disk; } \\
\text { VMS operating system }\end{array}$ & ISM, GAS \\
\hline $\begin{array}{l}\text { IBM PC's and } \\
\text { Macintoshes }\end{array}$ & $\begin{array}{c}\text { Denver } \\
\text { Menlo Park }\end{array}$ & Variable & $\begin{array}{l}\text { Graphics, technical word } \\
\text { processing, and administrative } \\
\text { applications }\end{array}$ \\
\hline
\end{tabular}

integrated with other computerized files for a wide variety of research applications.

Magoon (this report) defines petroleum system categories based on type of reservoir rock (siliciclastic or carbonate), type of source rock (I, II, or III), and whether a petrcleum system is purebred or hybrid. A system's level of certainty is indicated by (!) for known, (.) for hypothetical, and (?) for speculative. Additional data elements include the age and formation code for each petroleum system source rock and reservoir rock. These codes are derived from PI's age and formation code list (Petroleum Information Corporation, 1979) and can be expanded as needed. The full petroleum system name is also identified.

The file structure for the petroleum system data base is an 80-column card-image format (table 14). The first character is 9 which indicates the 14-digit API number format follows. The State and county code numbers from the API Bulletin D12A are placed in Columns 2 through 6 (American Association of Petroleum Geologists Committee on Statistics and Drilling, 1966; American Petroleum Institute, 1979). A right-justified unique number for each petroleum system is entered into columns 7 through 11. A 3-digit API province code is placed in columns 12 through 15 (Meyer, 1974). The county-distribution is that portion of a county, in percent from 1-100, that the petroleum system covers; this number is placed in columns 16 through 18. The remainder of the format includes: the name of the petroleum system in columns 19 through 35 ; its level of certainty in column 36 ; information to classify the system in columns 37 through 45; and the petroleum system name written out in the last 35 columns. The codes for the source rock and reservoir rock are from PI's WHCS file documentation.

Since most petroleum systems will occupy several counties, a county-distribution parameter has been included in the data base. For example, the Phosphoria-Weber petroleum system may occupy all or parts of many counties in the Rocky Mountain region. Thus, the county distribution parameter may equal 100 percent for many counties or less than 100 percent for others. Based on this file structure, a single petroleum system (a unique petroleum sequence number) may have many unique state and county identification numbers, and many county-distribution parameters. In this way, petroleum systems can be subdivided into geographic and geologic units; the data from these units can also be integrated with data from other data files.

The PSDB can be integrated with the WHCS well data base by unique API sequence numbers (American Petroleum Institute, 1979), province codes, age and formation codes, and gross lithology. WHCS data can be retrieved by any of these parameters, edited for accuracy, and integrated with other petroleum system data. Distributions such as total drilled feet, drilling completions through time, drilling by location, and undrilled thicknesses can be generated for each 
Table 14. File structure for an 80-column card-image format for the petroleum system data base [ A, alpha characters; X, numeric characters; API, American Petroleum Institute; PI, Petroleum Information Corporation; see Magoon (this report) for definition of petroleum system data elements]

\begin{tabular}{lccc}
\hline \multicolumn{1}{c}{ Data element } & Columns & Character type & Total characters \\
\hline Number "9", indicates API number format & 1 & X & 1 \\
API State (XX) and county (XXX) number & $2-6$ & XXXXX & 5 \\
Unique petroleum system number & $7-11$ & XXXXX & 5 \\
API Province code & $12-15$ & XXXX & 4 \\
County-distribution in percent ( $\leq 100)$ & $16-18$ & XXX & 3 \\
Source rock: geologic age and rock unit name (PI code) & $19-26$ & XXXAAAAA & 8 \\
Hyphen separating source and reservoir rock unit codes & 27 & - & 1 \\
Reservoir rock: geologic age and rock unit name (PI code) & $28-35$ & XXXAAAAA & 8 \\
Level of certainty: known (K), hypothetical (H), or speculative (H) & 36 & A & 1 \\
Geologic setting: purebred (pur) or hybrid (hyb) & $37-39$ & AAA & 3 \\
Reservoir rock type: siliciclastic (silic) or carbonate (carbo) & $40-44$ & AAAAA & 5 \\
Source rock type: I (1), II (2), or III (3) & 45 & X & 1 \\
Complete petroleum system name & $46-80$ & alpha & -35 \\
& & & Total 80 \\
\hline
\end{tabular}

petroleum system. Reservoir data from the PDS and NRG field files can be retrieved by reservoir or formation name, province, county, State, and latitudelongitude location and can be integrated with PSDB data. Production histories, geologic and engineering parameter summaries, and resource assessments can be easily produced for each petroleum system.

Additional applications include PSDB integration with the Branch of Petroleum Geology petroleum geochemistry file, published bibliographic files, and a host of published data generated by formation and geographic location.

The PSDB will be an effective mechanism to store, retrieve, and analyze information gathered through petroleum system research.

\section{REFERENCES CITED}

American Association of Petroleum Geologists Committee on Statistics and Drilling, 1966, Standard state, county, operator, and stratigraphic codes: Tulsa, American Association of Petroleum Geologists, $60 \mathrm{p}$.

American Petroleum Institute, 1979, The API well number and standard state and county numeric codes including offshore waters: API Bulletin D12A, Washington, D.C., American Petroleum Institute, $136 \mathrm{p}$.

Crovelli, R.A., and Balay, R.H., 1987, FASP, an analytical resource appraisal system for petroleum play analysis: Computers and Geosciences, v. 12, no. 4B, p. 423-475.

Dyman, T.S., 1978, Data on 80,000 fields available to industry: World Oil, v. 186, no. 1, p. 109-116.
Dyman, T.S., Materna, W.L., and Wilcox, L.A., 1985, Stratigraphic applications of the Geologic Analysis System (GAS)—A case study [abs.]: American Association of Petroleum Geologists Bulletin, v. 69, no. 2, p. 251.

Dynamic Graphics Corporation, 1986, Interactive Surface Modeling (ISM) users guide: Berkeley, Dynamic Graphics Corporation, 104 p.

Meyer, R.F., ed., 1974, Geologic provinces of the United States: Tulsa, Oklahoma, American Association of Petroleum Geologists, scale 1:5,000,000.

NRG Associates, 1985, The field/reservoir clusters of the United States: Colorado Springs, NRG Associates.

Petroleum Information Corporation, 1979 (with annual updates), Well History Control System (WHCS) manual: Denver, Petroleum Information Corporation.

— 1984, Geologic Analysis System (GAS)Technical services training manual: Denver, Petroleum Information Corporation, $195 \mathrm{p}$.

Waples, D.W., 1980, Time-temperature relation in petroleum exploration: Application of Lopatin's method to petroleum exploration: American Association of Petroleum Geologists Bulletin, v. 64, p. 916-926.

1981, Organic geochemistry for exploration geologists: Minneapolis, Burgess, $151 \mathrm{p}$.

Wilcox, L.A., Coit, T.A., and Magoon, L.B., in press, The National Petroleum Reserve in Alaska computer data and graphics system-An aid to geologic interpretation, in Gryc, George, ed., Geology of the National Petroleum Reserve in Alaska: U.S. Geological Survey Professional Paper 1399. 


\section{SELECTED SERIES OF U.S. GEOLOGICAL SURVEY PUBLICATIONS}

\section{Perlodicals}

Earthquakes \& Volcanoes (issued bimonthly). Preliminary Determination of Epicenters (issued monthly).

\section{Technical Books and Reports}

Professional Papers are mainly comprehensive scientific reports of wide and lasting interest and importance to professional scientists and engineers. Included are reports on the results of resource studies and of topographic, hydrologic, and geologic investigations. They also include collections of related papers addressing different aspects of a single scientific topic.

Bulletins contain significant data and interpretations that are of lasting scientific interest but are generally more limited in scope or geographic coverage than Professional Papers. They include the results of resource studies and of geologic and topographic investigations; as well as collections of short papers related to a specific topic.

Water-Supply Papers are comprehensive reports that present significant interpretive results of hydrologic investigations of wide interest to professional geologists, hydrologists, and engineers. The series covers investigations in all phases of hydrology, including hydrogeology, availability of water, quality of water, and use of water.

Circulars present administrative information or important scientific information of wide popular interest in a format designed for distribution at no cost to the public. Information is usually of short-term interest.

Water-Resources Investigations Reports are papers of an interpretive nature made available to the public outside the formal USGS publications series. Copies are reproduced on request unlike formal USGS publications, and they are also available for public inspection at depositories indicated in USGS catalogs.

Open-File Reports include unpublished manuscript reports, maps, and other material that are made available for public consultation at depositories. They are a nonpermanent form of publication that may be cited in other publications as sources of information.

\section{Maps}

Geologic Quadrangle Maps are multicolor geologic maps on topographic bases in 71/2- or 15-minute quadrangle formats (scales mainly $1: 24,000$ or $1: 62,500$ ) showing bedrock, surficial, or engineering geology. Maps generally include brief texts; some maps include structure and columnar sections only.

Geophysical Investigations Maps are on topographic or planimetric bases at various scales; they show results of surveys using geophysical techniques, such as gravity, magnetic, seismic, or radioactivity, which reflect subsurface structures that are of economic or geologic significance. Many maps include correlations with the geology.

Miscellaneous Investigations Series Maps are on planimetric or topographic bases of regular and irregular areas at various scales; they present a wide variety of format and subject matter. The series also includes 71/2-minute quadrangle photogeologic maps on planimetric bases which show geology as interpreted from aerial photographs. Series also includes maps of Mars and the Moon.
Coal Investigations Maps are geologic maps on topographic or planimetric bases at various scales showing bedrock or surficial geology, stratigraphy, and structural relations in certain coal-resource areas.

Oil and Gas Investigations Charts show stratigraphic information for certain oil and gas fields and other areas having petroleum potential.

Miscellaneous Field Studies Maps are multicolor or black-andwhite maps on topographic or planimetric bases on quadrangle or irregular areas at various scales. Pre-1971 maps show bedrock geology in relation to specific mining or mineral-deposit problems; post-1971 maps are primarily black-and-white maps on various subjects such as environmental studies or wilderness mineral investigations.

Hydrologic Investigations Atlases are multicolored or black-andwhite maps on topographic or planimetric bases presenting a wide range of geohydrologic data of both regular and irregular areas; principal scale is $1: 24,000$ and regional studies are at $1: 250,000$ scale or smaller.

\section{Catalogs}

Permanent catalogs, as well as some others, giving comprehensive listings of U.S. Geological Survey publications are available under the conditions indicated below from the U.S. Geological Survey, Books and Open-File Reports Section, Federal Center, Box 25425, Denver, CO 80225 . (See latest Price and Availability List.)

"Publications of the Geological Survey, 1879-1961" may be purchased by mail and over the counter in paperback book form and as a set of microfiche.

"Publications of the Geological Survey, 1962-1970" may be purchased by mail and over the counter in paperback book form and as a set of microfiche.

"Publications of the U.S. Geological Survey, 1971- 1981" may be purchased by mail and over the counter in paperback book form (two volumes, publications listing and index) and as a set of microfiche.

Supplements for 1982,1983,1984, 1985, 1986, and for subsequent years since the last permanent catalog may be purchased by mail and over the counter in paperback book form.

State catalogs, "List of U.S. Geological Survey Geologic and Water-Supply Reports and Maps For (State)," may be purchased by mail and over the counter in paperback booklet form only.

"Price and Availability List of U.S. Geological Survey Publicatlons," issued annually, is available free of charge in paperback booklet form only.

Selected coples of a monthly catalog "New Publications of the U.S. Geological Survey" available free of charge by mail or may be obtained over the counter in paperback booklet form only. Those wishing a free subscription to the monthly catalog "New Publications of the U.S. Geological Survey" should write to the U.S. Geological Survey, 582 National Center, Reston, VA 22092.

Note.--Prices of Government publications listed in older catalogs, announcements, and publications may be incorrect. Therefore, the prices charged may differ from the prices in catalogs, announcements, and publications. 
